\title{
On the species of the genus Selliporella SARTONI \& CRESCENTI, 1962 from the Middle Jurassic of the coastal Dinarides of Croatia
}

\author{
Branko Sokač \& Tonći Grgasović \\ Croatian Geological Survey, Sachsova 2, 10000 Zagreb, Croatia; (tgrgasovic@hgi-cgs.hr)
}

doi: $10.4154 / g c .2017 .15$

Article history:

Manuscript received August 03, 2017

Revised manuscript accepted October 04, 2017

Available online October 31, 2017

\begin{abstract}
An emended diagnosis of the genus Selliporella and its type-species, S. donzellii SARTONI \& CRESCENTI is proposed, based on the proven existence of non-ramified laterals in the mature (basal) part of the thallus and their ramification in its higher (juvenile) parts. Given the differences in the morphological characteristics of laterals in the upper parts of the thallus, the type-species has been split into two varieties: S. donzellii var. donzellii SARTONI \& CRESCENTI and S. donzellii var. galaeformis n. comb. Selliporella cornutuformis $\mathrm{n}$. sp. is proposed, characterized by a distinctly articulated (segmented) and spiky thallus, with each primary lateral bearing a bundle of several trichophorous secondaries. The generic attribution of species originally described as Diplopora johnsoni PRATURLON and Triploporella neocomiensis RADOIČIĆ has been reviewed, resulting in their being unified as the same species, which, according to its newly observed morphological characters, has been ascribed to the genus Pseudoclypeina. As Diplopora johnsoni has been validly described, Triploporella neocomiensis becomes, taxonomically, the younger synonym of Pseudoclypeina johnsoni (PRATURLON) n. comb.
\end{abstract}

Keywords: Selliporella genus, Dasycladales, taxonomy, biostratigraphy, Dinarides, Croatia

\section{INTRODUCTION}

The genus Selliporella SARTONI \& CRESCENTI, 1962 was established on the basis of inadequately illustrated, fragmented sections of individual whorls. Thus, the lack of more complete parts of thallus resulted, then, in an incomplete diagnosis as follows: „Essentially cylindrical thallus, with generally detached and separately fossilized whorls. Fertile whorls in a basket shape, each one formed by laterals of two or more superposed rows. Phloiophorous laterals are welded together. Laterals of the same row communicate with one another; but the laterals of the various rows of the same whorl have rare, sporadic and often absent communication." (SARTONI \& CRESCENTI, 1962). Such inadequate and even, to some extent confusing, diagnosis resulted in fragments or sections of different characteristics being ascribed to Selliporella donzellii, and even in the description of a new species, Teutloporella gallaeformis RADOIČIĆ, 1965, which, after the establishment of the new genus Neoteutloporella BASSOULLET et al., 1978, will be ascribed to the latter. In neither species description (Selliporella donzellii and Teutloporella gallaeformis) are the articulation of the thallus and the bipartite laterals explicitly mentioned, though RADOIČIĆ (1965) did show two sections with visible articulation (RADOIČIĆ, 1965, pl. IV, figs. 3-4). Besides, in the explanatory note to a figure RADOIČIĆ, (1965, pl. III, fig. 3), mentioned a type of annulation, which, however, she supposed to be a secondary feature, due to subsequent break-off, and which, therefore, cannot be related to original thallus annulation. Though frequently mentioned in various papers as evidence or confirmation of stratigraphic age, Selliporella donzellii was not, at that time, analysed in more detail. A short repeated description given by NIKLER \& SOKAČ (1967) was in many respects inaccurate and confusing, along with the photographs attached, which failed to give any contribution to a better understanding of the species-specific - and thus, implicitly, to the genus-specific - characteristics. In a later, more complete description of both the genus Selliporella and the species Selliporella donzellii, given by SOKAČ \& VELIĆ (1978), the presence of segments with two or three rows of whorls was explicitly mentioned for the first time, but still with an emphasis on undivided laterals of the piriferous type. However, as later emphasized by BARATTOLO et al. (1992), that addition could not be accepted due to the afore-mentioned morphological characteristics and also because the form illustrated by SOKAČ \& VELIĆ (1978; pls. I-V) didn't correspond to the type-species characteristics. A new amended diagnosis of Selliporella donzellii SARTONI \& CRESCENTI was given by BARATTOLO et al. (1992, p. 604). Based on analysis of numerous sections from samples collected from a number of localities in the Apennines and Dinarides, they gave a detailed description concerning the shape and distribution (arrangement) of bipartite laterals, the thallus morphology, with both the sections illustrated (BARATTOLO et al., 1992, pls. I-IV) and with graphic interpretation (BARATTOLO et al., 1992, figs. 1-4). They summed up the characters of the species as follows: „Euspondyle dasyclad alga uniformly articulated or, instead, articulated only in some regions of the thallus. Each article is provided of primary branches arranged in a couple of secondary branches. The primaries are short, and laterally compressed, they are subrectangular in cross-section. The secondary branches are trichoporous, sturdy, and relatively long; they are proximally perpendicular to the main axis but outwards they bend gradually upwards. They grow in tufts of two on each primary branch.“ Based on these characteristics of the type-species, they also gave a summary diagnosis of the genus, and commented on Neoteutloporella gallaeformis (RADOIČIĆ), for which they stated that it „might be“ a higher, non-segmented part of the Selliporella donzellii thallus, thus being its younger synonym. As for the form ascribed to Selliporella donzellii and illustrated in SOKAČ and VELIĆ (1978, pls. I-V), they emphasized its being impossible to be identified with the type-species, but possibly belonging to the same genus (i.e., Selliporella). 
After extensive investigations of numerous sections in the samples from the Dinaridic coastal region, it was noticed that only a part of these sections may be reliably ascribed to Selliporella donzellii, within the frame and according to the emended diagnosis of BARATTOLO et al. (1992). Quite a large amount of sections, contained in the type-species bearing sample, showed bipartite laterals differing in morphology from what was previously described. Some sections, rather rare in the bulk of algal fragments, mixed with variously preserved sections of the type species, differ from those in being distinctly smaller, showing an articulated thallus, and having mutually separated, undivided, clearly piriferous laterals. Taken individually, with their completely different morphology of both thallus and laterals, these sections appeared unidentifiable with Selliporella donzellii and, at first glance, suggested a possibility of belonging to the genus Neoteutloporella (A similar section was illustrated by RADOIČIĆ, 1965, pl. IV, fig. 4, and labelled? Teutloporella). We identified these sections as representing the basal parts of the thalli of the type-species.

However, in reviewing the existing descriptions and amendments, we noticed the lack of more detailed biometric parameter values. Thus in the original description (SARTONI \& CRESCENTI, 1962) there were only three values mentioned (L, D, w) or, if we take Neoteutloporella gallaeformis as a younger synonym of Selliporella donzellii, two more can be added $(1, p)$. The position of sections figured by SOKAČ \& VELIĆ (1978, tab. I-V) and ascribed to the type-species, remain unsolved. Such open questions resulting from earlier papers, and more of the same, inspired us to undertake a revision of our own earlier determinations and opinions.

In this paper, we again analysed numerous algal-bearing samples from several localities in the central and southern Dalmatian coastal area (Mt. Biokovo, the environs of Neum, Osojnik NW of Dubrovnik, as well as the Konavle hills SE of Dubrovnik). The samples analysed and illustrated here have been collected by several researchers from the Croatian Geological Survey (former Institute of Geology) during the last 30 years or so. Their localities with Greenwich coordinates are listed below:

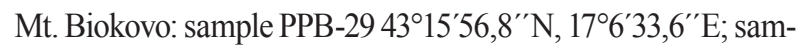

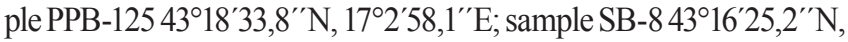
$17^{\circ} 6^{\prime} 15,7^{\prime \prime} \mathrm{E}$

Environs of Neum: sample NU-41 42 $56^{\prime} 28,5^{\prime \prime} \mathrm{N}, 17^{\circ} 37^{\prime} 25,4^{\prime \prime} \mathrm{E}$

Environs of village Osojnik: sample OS-9 $42^{\circ} 42^{\prime} 14^{\prime \prime} \mathrm{N}$,

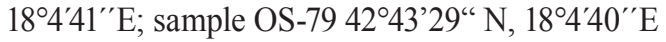

Konavle hills: sample KOB-372 42 $35^{\prime} 51^{\prime \prime} \mathrm{N}, 18^{\circ} 17^{\prime} 32,3^{\prime \prime} \mathrm{E}$

After the analysis of the aforementioned samples we came to the following conclusions:

- Selliporella donzellii is highly variable with regard to the morphology of the thallus and laterals, depending primarily on which parts of thallus, i.e. mature or juvenile, are compared;

- That the emendation of Selliporella donzellii SARTONI \& CRESCENTI as given by BARATTOLO et al. (1992) is fully applicable only for juvenile (higher) parts of thallus;

- That the supposition in the separately given opinion of Barattolo and De Castro in BARATTOLO et al. (1992), that Teutloporella gallaeformis RADOIČIĆ is a younger synonym of Selliporella donzellii, i.e., its juvenile (higher) thallus part, is correct. Sections with the characteristic shape and bulkiness of the secondary laterals, usually il- lustrated under the name Teutloporella gallaeformis, should be separated as a new variety of the type-species;

- That the sections illustrated in SOKAČ \& VELIĆ (1978, tab. I-V) under the name Selliporella donzellii SARTONI \& CRESCENTI, whose assignment to that species was questioned by BARATTOLO et al. (1992), doubtlessly belong to the genus Selliporella and can be singled out as a new species, introduced here as Selliporella cornutuformis n. sp.;

- That the biometric parameters of the type-species should be given separately for different parts of its thallus;

- That the variability in the building elements of Selliporella donzellii is intraspecific, but individual specimens with distinctly pronounced peculiar morphologic characteristics may be separated as varieties of the same species.

- That a new description of Selliporella donzellii SARTONI \& CRESCENTI is needed.

Moreover, discussion of the generic attribution of the species originally described under the name Triploporella neocomiensis RADOIČ́Ć, which was subsequently transferred to Selliporella is warranted (BUCUR \& SĂSĂRAN, 2003).

\section{SYSTEMATIC PALAEONTOLOGY}

\section{Selliporella donzellii SARTONI \& CRESCENTI var. donzellii}

Pls. I - IX

After studying a large number of variously oriented sections in one or several samples, a new and more complete understanding of the very variable morphology of the thallus as a whole and of changing type and shape of laterals from undivided to divided has arisen. Laterals may be present in sections cutting different parts of the thallus, depending on their growth stage.

Dimensions in $\mathrm{mm}$ :

\begin{tabular}{lccc}
\hline & $A$ & $B$ & $C$ \\
\hline$L=10,46$ & & & \\
\hline D & $0,58-1,70$ & $1,44-2,52$ & $1,70-3,78$ \\
d & $0,16-0,82$ & $0,48-1,05$ & $0,34-0,98$ \\
d/D & $0,230-0,500$ & $0,200-0,541$ & $0,210-0,356$ \\
h & $0,14-0,46$ & $0,20-0,62$ & $0,28-0,30$ \\
p & $0,04-0,16$ & - & - \\
p' & - & $0,05-0,24$ & $0,16-0,30$ \\
p'" & - & $0,06-0,20$ & $0,18-0,30$ \\
I & $0,50-0,94$ & - & - \\
I' & - & $0,24-0,30$ & $0,20-0,35$ \\
I' $^{\prime \prime}$ & - & $0,48-0,72$ & $0,50-1,10$ \\
w & $6-12$ & $12-20$ & do 30 \\
a & $20-50^{\circ}$ & & \\
\hline
\end{tabular}

Explanation of symbols:

A - lower (mature) part of thallus; B - middle part of thallus; C - upper (juvenile) part of thallus

$L$ - maximum observed length

D - outer diameter

$\mathrm{d}$-inner diameter

$d / D$ - relationship between inner and outer diameter

$\mathrm{h}$ - distance between consecutive whorls

$\mathrm{p}$ - diameter of laterals at their widest

$p^{\prime}$ - diameter of primary laterals

$p^{\prime \prime}$ - diameter of secondary laterals at their widest

I - length of laterals

I' - length of primary laterals

I" - length of secondary laterals

w- number of laterals per whorl

$w^{\prime}$ - number of secondaries on a primary lateral

$w^{\prime \prime}$ - number of tertiaries on a secondary lateral

$a$-dip of laterals from horizontal plane 
The calcareous thallus has a rather variable shape, depending on the distance between neighbouring whorls, the shape of undivided or divided laterals, and their inclination. Basal (= mature) part of thallus is distinctly articulated, and thus acquiring a spiny (spinose) shape, as a result of clearly separated whorls of piriferous laterals with distally individualized calcareous envelopes (Pl. I, figs. 1-5, 7-9). Going upwards, laterals became divided (Pl. I, fig. 6, Pl. IV, figs. 1-2; Pl. V, fig. 5), resulting in more massive articles, with, in some sections, visible annulation in between (Pl. IV, figs. 1-2; Pl. VI, fig. 8; Pl. VII, fig. 7; Pl. VIII, fig. 1). In other sections, annulation is unclear or absent. Each article represents one whorl. In higher (= juvenile) parts of the thallus, the distance between neighbouring whorls gradually diminishes, while the diameter of both primaries and secondaries, as well as the height of the articles, visibly increases, with reduced annulation which leads to the appearance of a seemingly non-articulated thallus. In some sections of the juvenile part of the thallus horizontal fissures are visible (Pl. VI, fig. 8, part.; Pl. VII, fig. 6, part.; Pl. VIII, figs. 6,8), which represent reduced annulation resulting from calcification of the individual whorls of ramified laterals. Vertical, oblique, or irregular, sections, observed in places (Pl. VII, fig. 1-2, bottom; Pl. VIII, fig. 9), mainly divide pairs of secondary laterals, as a result of the calcification of individual laterals. Generally, annulation is typically present in the basal part of the thallus, more or less displayed in middle parts, and reduced in the upper parts. That is a result of differences in the distance between neighbouring whorls and the shape and the inclination of the laterals, together with the presence of individual calcareous sheets (DE CASTRO, 1997) of laterals. In its basal part, the thallus is cylindrical and distinctly annulated, becomes slightly club-shaped, with reduced annulation and thus acquiring a seemingly compact shape (Pl. IV, fig. 8; Pl. V, fig. 2; Pl. VII, fig. 6). Outer surfaces of the upper parts, strewn with shallow spines, are a consequence of individual calcareous sheets of the secondaries' distal ends (Pl. V, fig. 2; Pl. VI, figs. 2-3; Pl. VII, figs. 2-3; Pl. VIII, fig. 5). In the basal and middle parts of the calcareous skeleton, the central cavity is cylindrical and delineated with a continuous thin black micrite layer (Pl. I, figs. 3-4; Pl. II, figs. 1, 3-4, 7-8; Pl. IV, figs. 1-7, 8-9). In the upper parts of the thallus, this black layer is seldom continuous (Pl. V, part. figs. 1-2, 4; Pl. VIII, figs. 2-3, $6)$; more frequently, it disappears due to erosion of the thallus interior (Pl. V, figs. 1-2) or due to the connected pores of the proximal ends of neighbouring primary laterals (Pl. IV, fig. 8; Pl. V, fig. 6; Pl. VII, fig. 3). In earlier papers (SARTONI \& CRESCENTI, 1962), these features were described as circular ,,annular" canals. The central cavity occupies, on average, $20-40 \%$ of the outer thallus diameter.

Euspondylity is clearly visible in all parts of the thallus. As already mentioned, going from the mature to juvenile parts of the thallus, the type of laterals, their shape, and their number per whorl change. In the basal thallus parts, the laterals are piriferous simple (undivided), not distinctly pear shaped (Pl. I, figs. 1-5, 7-9; Pl. II, figs. 2, 4-5, 7-9; Pl. IV, fig. 1 bottom). By their proximal ends, the laterals of the same whorl are mutually in close contact, thus forming an uninterrupted calcareous ring. (Pl. III, figs. 1-3, 6-7). More distally, the laterals of the same whorl grow more wide apart and became more clearly separated, each one being enveloped in a thin individual calcareous sheath, giving the thallus a distinctly spiky (spinose) appearance. The number of laterals in a whorl at this level of the thallus increases gradually from a minimum of 6 (Pl. III, fig. 7) to 10-12 (Pl. III, figs. 1-2, 6, 8-9). The laterals are directed obliquely upwards, under an angle of $20^{\circ}$ - $50^{\circ}$, more steeply in the upper thallus parts (Pl. I, figs. 1, 3-5, 7-8), Also, going to higher levels, the simple (undivided) laterals pass into ramified laterals, more gently inclined to the horizontal plane (Pl. IV, fig. 1). The appearance of the first ramified laterals is characterized by variably shaped primaries, ranging from short tubu$\operatorname{lar}(\mathrm{Pl}$. IV, fig. 3, 5, 9), proximally more or less irregularly widened (Pl. IV, part fig. 5, 7, fig. 8 bottom), to visibly swollen (Pl. IV, fig. 1 top, fig. 8 top). In the middle part of the thallus, the proximal ends of the primaries are, in general, well preserved, so that the central cavity is still clearly defined (Pl. IV, figs. 2-7, 9-10, 8 bottom). Articulation here can be either clearly pronounced ( $\mathrm{Pl}$. IV, figs. 1-2 top; Pl. VI, fig. 8; Pl. VII, figs. 5, 7) or just indicated, but barely observable. Going upwards, the primaries became larger, of ellipsoidal, or irregularly circular shape (Pl. V, figs. 2-3, 6) or, sometimes, with lowered (dropped) bases, acquiring a stocky, basket-like shape (Pl. V, fig. 2; Pl. VI, fig. 1; Pl. VII, fig. 5), as mentioned and illustrated by BARATTOLO et al. (1992, fig. 3), thus indicating the pronounced variability in the primaries' shape. In the upper parts of the thallus, the number of laterals per whorl varies from 20 to 30 . The distance between neighbouring whorls decreases, leading to ever more close contact of their laterals (Pl. VI, fig. 1), sometimes to the joining of their pores in their proximal parts (Pl. V, fig. 6; Pl. VII, figs. 2-3). In this region of the thallus, the primaries are most frequently, partly or completely, destroyed, their shape being recognizable only with difficulty, with a secondarily widened and indistinctly delineated central cavity (Pl. IV, fig. 8 top; Pl. V, part. fig. 2; Pl. IX, fig. 1). Such an appearance is caused by the laterals being pressed together and, consequently, having thinner (or non-existent) calcareous envelopes, easily prone to destruction.

Each primary lateral bears a pair of piriferous secondaries, of which the lower one is always larger, attaining up to three times a larger diameter then that for the upper lateral, and having a more distinctly piriferous shape. In tangential sections through the upper parts of the thallus, the different diameter of the secondaries belonging to the same pair, is indicated by alternately occurring large and smaller pores (Pl. VI, fig. 8; Pl. VII, figs. 6-7; Pl. VIII, fig. 8). The secondaries, though being approximately horizontal in their proximal parts, going outwards gradually bend upwards and their calcareous envelopes become separated. In the distal tangential sections, this feature gives a picture of an joint envelope of the same pair (outer parts of the skeleton being fissured), whereas in the top parts it appears as single circular pores with individual envelopes (Pl. VII, fig. 2 bottom, Pl. VIII, fig. 9; Pl. IX, fig. 2 top) and shallow spinose outer surface. Laterals of the same pair grow one above the other, but going upwards, the direction of growth of the thinner, upper lateral slightly diverges sideways, in relation to the lower, larger lateral. In tangential sections this appears as an alternating distribution of rows with larger pores, belonging to larger lower laterals, and rows of smaller pores, deriving from thinner, upper laterals of neighbouring pairs of the same whorl (Pl. VII, fig. 6-7; Pl. VIII, fig. 8; Pl. IX, fig. 2 top). Variability concerning the size and shape of the lower, larger secondary lateral is very frequent, whereas the dividing (branching) of the secondaries is anomalous and occurs only rarely (Pl. V, fig. 3 arrow). Specimens with enormously large and visually variously shaped secondaries have been singled out as the new variety.

The species is most likely cladosporous, a conclusion based on the large relative size of its laterals. This may be supported by the presence of single micritic bodies of $0.10 \mathrm{~mm}$ in diameter, possibly representing dispersed cysts, that have been observed in 
the primaries, and more frequently in the larger of the secondaries (not illustrated).

The type species is characterized by a wide range of morphology from the basal to the top part of the thallus. This is due to the type of laterals, their gradual increasing number per whorl going upwards, their variable declining angle in relation to the central axis of growth, variable distance between the neighbouring whorls, their more or less pronounced growth (becoming larger) of the primaries and secondaries, leading to variable values of outer and inner diameters.

We propose the following emended diagnosis of Selliporella donzellii SARTONI \& CRESCENTI: The type species of the genus Selliporella is clearly euspondyle, cylindrical to slightly claviform shape, distinctly articulated in the lower parts and with reduced annulation in the upper parts. In the lower part, it has undivided piriferous laterals, each having a distally individualized calcareous envelope. Going upwards, the undivided laterals pass into clearly differentiated primaries and secondaries. Each primary lateral bears a pair of more or less distinctly piriferous secondaries, which diverge laterally.

In accordance with the emended species-specific diagnosis, we propose the following emended generic diagnosis of the genus Selliporella SARTONI \& CRESCENTI: Cylindrical to slightly claviform, more or less segmented thallus. Laterals arranged in whorls, undivided in the lower part of the thallus, divided in the upper. Primaries of variable shape, from tubular to more or less inflated. Secondaries trichophorous to piriferous.

Selliporella donzellii SARTONI \& CRESCENTI var. gallaeformis (RADOIČIĆ) n. comb., n. var.

Pl. III, fig. 13a; Pl. VIII, fig. 6b; Pls. X-XII

The establishment of a new variety within Selliporella donzellii SARTONI \& CRESCENTI is based on differences between individual biometrics in the upper thallus part with regard to the same parameters in the typical variety. This results in morphological variability, intensity of calcification, and, thus, the state of preservation. The lack of sections of transition from the lower to the upper part of the thallus in S. donzellii var gallaeformis may be a question, but the discovery of such a section is merely luck. For $S$. donzellii, along with its numerous illustrations by many authors, the transition from the lower to the upper part of the thallus has only been observed in a few sections, in the 50 years from its first description.

In numerous sections derived from the same sample (O-79), the new variety is represented by about $10 \%$ of the total number of sections of the various parts of the thallus of the type species. The analysed and illustrated sections (Pls. X-XII) have been ascribed to the upper parts of the typical variety, because other thallus parts, which would, by their characteristics, diverge from the above described in the typical variety of Selliporella donzellii, have not been observed. Moreover, some sections (Pl. IX, figs. 3-4) partly include features characteristic of both varieties, which, in such cases, makes their undoubted separation impossible, but clearly indicates their belonging to the same species.

In the analysed material, Selliporella donzellii var. gallaeformis is present with variously oriented sections and frequently preserved only by the outer, peripheral parts of the thallus (Pl. III, fig. 13a; Pl. X, figs. 4-6), with more or less preserved secondaries. This makes a more detailed insight into the inner morphology impossible, particularly for the primaries, and also prohibits obtaining more numerous biometric parameters and their mutual relationships. The outer diameter (D) can reach $5 \mathrm{~mm}$. As a rule, the central cavity is secondarily widened through destruction of the primaries and the proximal parts of the secondaries (Pl. X, figs. 3-4; Pl. XIII, figs. 1, 4, 6), most probably because of poorly developed calcification in this part of the alga (Pl. X, fig. 9; Pl. XI, figs. 7, 9; Pl. XIII, fig. 8). Only a few sections (Pl. X, fig. 9; Pl. XI, figs. 7, 9; Pl. XII, fig. 8) enable partial, but insufficient, insight as to the shape and dimensions of the primaries. The impression is, they are much larger, more irregular, and, more often than in the typical variety, proximally compressed, both in the case of the laterals of the same whorl and those of the neighbouring whorls, which makes questionable the existence of an integral inner calcareous envelope, suggesting, instead, its honey-combed structure.

Secondary laterals are of the piriferous type, and because of the destruction of their proximal parts, their growth in pairs and the relationship with the primaries are only rarely observable. Thus, these features make the main and recognizable characteristics of the new variety. In sections, the visibly piriferous secondaries are very large, having much larger diameters than the same values in the typical variety, and are of a different shape, being distinctly piriferous (Pl. X, figs. 2, 5; Pl. XI, figs. 4, 9), baggy elongated (Pl. X, fig. 8; Pl. XI, figs. 1, 8; Pl. XII, figs. 1-2), or irregular (Pl. X, figs. 1, 4; Pl. XI, fig. 7; Pl. XII, figs. 7-8), and different shapes may appear in the same thallus. Secondary laterals of the same pair, in the typical variety being distinguishable by different diameters (lower ones are larger and with larger diameter, upper ones thinner), in this variety this distinction can be seen only in a few sections (Pl. X, fig. 3 top), so this feature remains unclear. The secondaries are distinctly swollen in the first third or half of their total length, except for those that are baggy or irregularly shaped (Pl. X, figs. 2, 6, 9; Pl. XII, fig. 8). More distally, more or less bent upwards, they, either gradually or abruptly, taper into spiny terminations of individual calcareous envelopes. Because of being swollen, the secondaries of both the same whorl and of the neighbouring whorls are tightly pressed together, compressing each other and leading to vertical and lateral deformations. In tangential sections or in part of the tangential sections, vertical or approximately vertical sections of laterals appear as more or less rounded (Pl. X, fig. 3; Pl. XI, figs. 5-6), polygonal or irregular, sometimes distinctly deformed pore shapes (Pl. X, part. fig. 6; Pl. XI, figs. 4, 6; Pl. XII, fig. 3). Individual circular bodies, $0.1 \mathrm{~mm}$ in diameter can be observed, dispersed in the secondaries' cavities, only rarely grouped together within a common envelope, elliptical in section, with longer axis of $0,24-0,28 \mathrm{~mm}$, shorter axis of 0,15-0,17 mm, and 6-?10 particles in a group (Pl. XI, fig. 5; Pl. XII, figs. 9-10, arrow). These circular bodies are probably cysts.

\section{Selliporella cornutuformis n. $\mathrm{sp}$.}

Pl. XIII - XVI

The species name derives from the spiky segments, which give such an appearance to the whole thallus.

Type locality: Mt. Biokovo (South Croatia), in a road cut situated between „Lemišini doci“ and „Ravna Vlaška“ localities (fig. 1). It is Stop 9 of the 9 th International Symposium on Fossil Algae Field Trip (SOKAČ \& VELIĆ, 2007). Coordinates: $43^{\circ} 16^{\prime} 25.2^{\prime \prime} \mathrm{N}, 17^{\circ} 6^{\prime} 15.7^{\prime \prime} \mathrm{E}$.

Type stratum contains numerous algal remnants in algal fenestral biomicrites with corrosion cavities, geopetal internal sediment and microcrystalline cement. Sporadically late diagenetic dolomite appears. The sedimentary environment is determined 


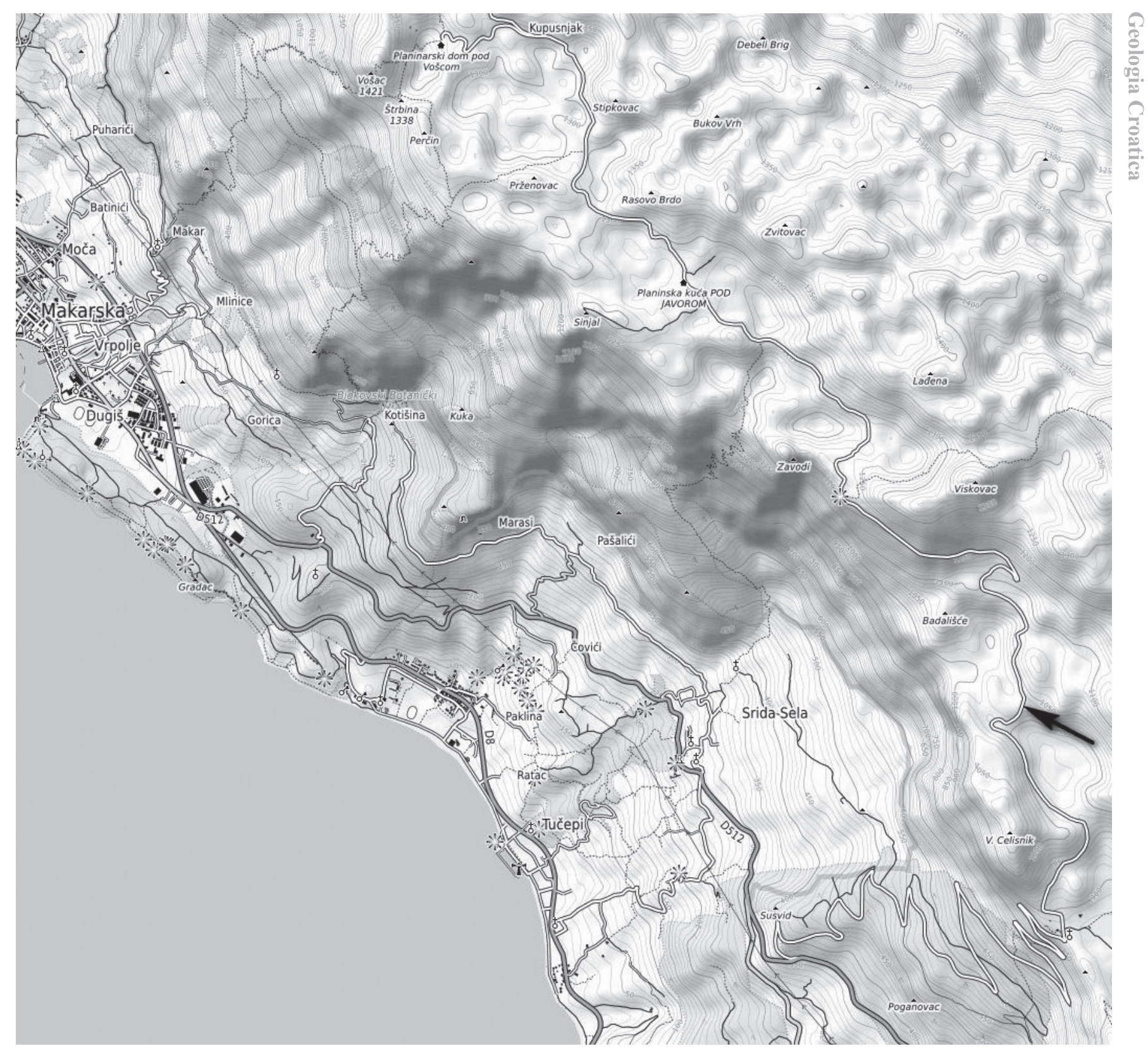

Figure 1. Location of Selliporella cornutuformis n. sp. type locality in the central Biokovo Mt. (arrow). Map: opentopomap.org.

as the upper intertidal zone with vadose diagenesis and shortterm emersions with palaeokarstification.

Holotype: Longitudinal, slightly oblique section in slide SB$8 \mathrm{~B} / 12$, figured in Pl. XIV, fig. 2. Isotypes are represented by variously oriented sections, figured in Pls. XIII-XVI. The entire material of Branko Sokač's personal collection in the Croatian Geological Survey will be permanently stored, after publication, in the Croatian Natural History Museum, Zagreb.

Diagnosis: Cylindrical, slightly claviform skeleton, distinctly articulated; comparatively regular central cavity slightly constricted in the level of whorls and slightly widened between neighbouring whorls, situated rather far apart. Each article bears one whorl of ramifying laterals. Primary laterals are small, tuberous or elongated, bearing secondaries in a finger-like arrangement. The number of laterals per whorl increases from the basal to upper parts of the thallus. Secondary laterals of the piriferous type, with variously inclined growth directions and distally indi- vidualized calcareous envelopes give the alga a distinctly spiky (spinose) appearance.

Description: Generally cylindrical skeleton is distinctly articulated. Slightly claviform shape is due to gently but gradually increasing of the segments' outer diameter from the basal to the top parts (Pl. XIII, fig. 1). Each article represents the calcified part between the ramified laterals of the same whorl. The distance between consecutive whorls is relatively large, but varies from specimen to specimen. Height and diameter of individual articles gently increases from the basal to the top part of the thallus, depending on the number, length, and inclination of the laterals. (PI. XIII, fig. 1). The calcareous envelope between the segments is the thinnest immediately above the lower segment and slightly thickens going toward the upper one, thus acquiring the shape of an inverted cone which passes, more or less abruptly, into the next (superimposed) segment (Pl. XIII, figs. 3, 5-6; Pl. XIV, figs. 1-2, 5).

The calcareous skeleton is composed of grainy calcite (sparite), bordered by thin, black, micritic envelopes. Sparry crystals 
represent the filling of the mould cavity, which remained after the primary, most probably aragonitic, skeleton, was dissolved. A thin micritic lining, enveloping the central cavity and the inner parts of laterals, is, generally, of very uniform thickness (Pl. XIII, fig. 1 lower part; Pl. XIV, figs. 2-3, 5-6; Pl. XV, figs. 6, 8-11; Pl. XVI, figs. 9-11) and possibly represents the primary micritic algal envelope. In places, this micritic envelope is of uneven thickness, sometimes in the interior of the thallus and more frequently on the outer wall, being probably the result of the activity of endolithic and epilithic microbes.

The central cavity displays a more or less well pronounced narrowing at the levels of whorls, and slight widening in the intervals between the whorls (Pl. XIII, figs. 1, 3; Pl. XIV, figs. 2, 5; SOKAČ \& VELIĆ, 1978, Pl. I, fig. 3).

The euspondyle character of the species is pronounced by clearly visible, mutually separated whorls, which, in the basal parts, bear undivided laterals, and in the upper parts, ramifying ones. The unramified, piriferous laterals of the basal parts of the thallus, are inclined steeply upwards (Pl. XV, fig. 8), and going upwards pass into ramified primaries and secondaries (Pl. XIII, fig. 1; Pl. XV, fig. 5; Pl. XVI, fig. 7). The exit of a lateral from the central cavity is realised through a tiny pore, which continues into a short tubular canal (Pl. XIII, fig. 3; Pl. XIV, fig. 5; Pl. XV, fig. 1 arrow, 13), which often suddenly widens into a tuberous shaped swelling (Pl. XVI, fig. 5, arrow; SOKAČ \& VELIĆ, 1978; Pl. I, fig. 3), longitudinally elongated (Pl. XIV, fig. 5) or globular shape (Pl. XV, fig. 6 arrow,?fig. 10-11; SOKAČ \& VELIĆ, 1978, Pl. III, fig. 5) and from which in finger-like arrangement, piriferous secondaries grow out. In spite of the large number of variously oriented sections, the relationship between the proximal swelling of the primary lateral and the secondary laterals, remain unclear. The piriferous secondaries, directed toward the outer surface, grow in various directions, directed both upwards and downwards (Pl. XIII, figs. 1, 4-6; Pl. XVI, figs. 5-6). In segments with ramified laterals, in different planes of section, the visible number of the secondaries per primary lateral varies from 3 to 4 (Pl. XIII, figs. 4-5; Pl. XV, figs. 1, 4, 6). In deeper tangential sections of individual segments, in the supposedly upper parts of the thallus, the pores suggest a bundle of as much as five secondaries (Pl. XIV, fig. 8; Pl. XV, fig. 12), which, however, remains questionable with regard to the possibility of intergrowth of neighbouring laterals. Individual calcareous sheets of the secondaries distally separate, becoming independent and sticking out like spines. The spines are fragile and the peripheral parts of the thallus are therefore partly or completely eroded, which makes the full value of the outer diameter (D) inadequately defined.

Similarities and differences: Selliporella cornutuformis $\mathrm{n}$. sp. includes the main characteristics of the genus, comparable to the type species: euspondility, unramified or ramified laterals depending on the growth age of thallus (lower or upper part), distally individualized secondaries, articulation of the skeleton, and similar values of biometric parameters. In addition to the similarities, specific characteristics of the two species enable their clear separation. Selliporella cornutuformis n. sp. is characterized by a much larger distance between the neighbouring whorls, strongly pronounced alternation of articles, mutually connected by conical parts of the thallus below the whorls along the entire length of the skeleton, which is lacking in the upper parts of Selliporella donzellii. In the upper parts of the type species, the central cavity is often secondarily widened, due to erosion of poorly calcified densely arranged whorls, and clearly bordered by a micritic envelope in the lower parts of the thallus, as distinct from the new species, in which the central cavity is clearly delimited along the whole length, with constrictions at the level of whorls and slight widening in the intervals between the whorls. The other main difference between the two species concerns the shape of the primary laterals and the number of the secondaries. In the type species, the laterals in the upper part of the thallus grow out in pairs, the lower lateral being, as a rule, larger and distally more or less directed upwards, with individualized calcareous envelopes only at their distal ends. In the new species, with only primary laterals in the basal part, with their ramifying in the upper parts, the number of secondary laterals varies from 3 to 4 (questionably 5). As distinct from the type species, in the new species the piriferous secondaries are of more uniform diameter along their length, diverging from each other and directed both upwards and downwards. In the new species, the individualization of calcareous envelopes of the secondaries occurs as early as in the first third or half of their total length, giving the segments a clearly spiky appearance, as distinct from the type species, in which the separation of calcareous envelopes of individual secondaries occurs only at their distal ends.

Stratigraphic position: At all localities where observed, Selliporella cornutuformis $\mathrm{n}$. sp. derives from various levels of the Selliporella donzellii biozone. The accompanying fossil contents, varies from locality to locality. It is most frequently associated with more or less numerous sections of the type species, with clear predominance either of the new species, or of the type species. At the Osojnik locality (sample O-79), in the wealth of algal remains, the type species is represented by both varieties, accompanied by frequent sections of Uragiella ragusina SOKAC and particularly numerous Salpingoporella croatica SOKAČ (the latter has been wrongly considered synonymous with Salpingoporella annulata CAROZZI by CARRAS et al., 2006, p. 160). Based on foraminiferal assemblages from both under- and overlying beds, VELIĆ $(2005,2007)$ defines the range of the type species Selliporella donzellii SARTONI \& CRESCENTI in the Mt. Biokovo area as extending from the early Bajocian to the late Bathonian. This also defines the stratigraphic range of the new species.

Note on the generic attribution of the species originally described as Triploporella neocomiensis RADOIČIĆ, 1963

The generic attribution of the species originally, but invalidly, described as Triploporella neocomiensis RADOIČIĆ, has been, for years past, considered by several authors. Most lately it was ascribed to Selliporella by BUCUR \& SĂSĂRAN (2003), which motivated us to include it in this paper.

Diagnosis of Triploporella neocomiensis, as described by RADOIČ́Ć (1963), represented this alga by an articulated thallus and with a broad central cavity. Each article corresponds to one whorl of 16 spherical, somewhat laterally compressed, primary laterals, each bearing a bunch of about 10 secondary laterals of variable length. At the same time, while the paper of RADOIČIĆ (1963) was in press, PRATURLON (1964) established Diplopora johnsoni, with approximately identical characteristics. This great similarity between the two species, prompted BUCUR \& SĂSĂRAN (2003) to publish comparable, side by side, tables of their biometric parameters and the description of important morphological characteristics, leaving the conclusion of their identity (i.e., synonymy), open, with the recommendation to restudy the type material of Diplopora johnsoni PRATURLON. If this recommendation is accepted, it would question the correctness of a number of previous emendations and novae combinationes of numerous species belonging to various genera. In our opinion, Triploporella neocomiensis RADOIČIĆ, 1963, in 
spite of minor differences in the original author's description, gains its validity only in the paper of RADOIČIĆ (1975), thus being clearly the younger synonym of Diplopora johnsoni PRATURLON, 1964. The generic attribution of these species, which were in earlier papers attributed to various genera, suggests the necessity of further analysis, based on both a comparison of the literature data and the analysis of our material, collected from the Lower Cretaceous deposits of Mt. Dinara and the island of Mljet.

The generic attribution of Triploporella neocomiensis RADOIČIĆ was first questioned by GRANIER (1988). He disputed its attribution to Triploporella and ascribed it formally (though questionably) to the genus Pseudoclypeina as Pseudoclypeina? neocomiensis RADOIČIĆ, 1963 n. comb., based on the similarity of its morphology with that of Pseudoclypeina crnogorica RADOIČIĆ, but without detailed discussion. GRANIER \& DELOFRE (1993), however, did not comment on its generic status and thus retained its original name. This possible abandoning of GRANIER's opinion (1988) and following emendation of the generic diagnosis of Selliporella (BARATTOLO et al., 1992) probably prompted further re-investigation of the generic attribution of Triploporella neocomiensis. Thus YILMAZ (1999), on the basis of the similarity of its morphological characteristics with the emended diagnosis of the genus Selliporella, mentioned it, informally, under the name Selliporella cf. neocomiensis RADOIČIĆ. Similarly, it will be informally ascribed to Selliporella by SĂSĂRAN \& BUCUR (2001). BUCUR \& SĂSĂRAN (2003) compared the emended diagnosis of the genus Selliporella with morphological characteristics of Triploporella neocomiensis RADOIČIĆ and proposed to be included into the genus Selliporella, introducing it, formally, as Selliporella neocomiensis (RADOIČIĆ, 1975 non 1963) n. comb. In this comparison BUCUR \& SĂSĂRAN (2003) accept the trichophorous type of laterals as the main diagnostic feature defining its assignment to the genus Selliporella, referring mainly to the reconstruction of the branches in RADOIČIĆ (1963, fig. 1), which, however, cannot be accepted as an accurate representation of the illustrated sections. Examining the illustrated sections of both the species originally described as Triploporella neocomiensis and the identical Diplopora johnsoni does not enable a decisive conclusion to be reached on the trichophorous type of secondary laterals, because their distal ends are not preserved in a single one of the rather numerous illustrated sections (RADOIČIĆ, 1963, Pls. 1- 5; PRATURLON, 1964, figs. 12-16; JAFFREZO, 1974, Pl. I, fig. 4, Pl. II, figs. 11-12; LUPERTO-SINNI \& MASSE, 1986, P1. 3, figs. 4-5; MANCINELLI, 1992, Pl. II, figs. 8-10; LUPERTO-SINNI \& MASSE, 1993, Pl. 1, figs. 9-10). Though in the description of Diplopora johnsoni the author mentions long, thin (i.e., trichophorous) laterals, he later wrote that they sometimes present distally a sharp widening, continuing into thin assimilatory filaments. Also, the existence of trichophorous type secondaries cannot be deduced from sections illustrated in the paper by BUCUR \& SĂSĂRAN (2003, Pls. I-III), to which the authors do not refer; furthermore, the sections (Pl. II, fig. 1 top; enlarged details in the same plate, figs. 7-9), by the club-shaped primaries and the pores of the secondaries, appear very close to some sections of Pseudoclypeina? crnogorica RADOIČIĆ, 1972, emend RADOIČIĆ, CARARAS \& CONRAD, 2013. However, BUCUR \& SĂSĂRAN (2003) did not comment on the comparison between those two morphologically similar species, attributed to different genera. As the type of the secondaries (interpreted as trichophorous), though questionable, was considered to be decisive to the generic attribu- tion, so their number in a tuft on the primary lateral, too, remained questionable. According to comparative table in BUCUR \& SĂSĂRAN (2003, table 1), the number of secondaries varies from 7 to 10 . Analysis of the illustrated sections in their paper suggests that the number is maybe lower (5-6) Some of the published sections suggest the possibility of tertiary laterals (RADOIČIĆ, 1963, Pl. 1, fig. 1 topmost part). A similar situation occurs with the section figured in BUCUR \& SĂSĂRAN (2003, Pl. III, fig. 10), if it refers to the same form. The same question of the number of secondaries and the existence of tertiaries remains unanswered in the description of Diplopora johnsoni PRATURLON.

In conclusion, there are some unclear points in the descriptions of Triploporella neocomiensis and Diplopora johnsoni, in which some mentioned morphological characteristics seem more to reflect the authors' impression than to be confirmed by the figured sections. All these suggest that an emended description and generic attribution are needed, more so because of our conviction of the two species being identical.

We consider, on the base of the analysis of our material and the analysis of published illustrations, together with the fact that we changed the diagnosis of the genus Selliporella, that the characteristics of this alga fit best to the genus Pseudoclypeina RADOIČIĆ (1970). BUCUR (2014) discussed the characteristics of the genus Pseudoclypeina based on the shape of the primary branches, their biometric relationship with the secondary branches and the type of calcitization of the skeleton which is in three species assigned to the genus Pseudoclypeina represented by the yellowish fibrous calcite $(P$. cirici, $P$. farinacciae, and $P$. distomensis). As for the species P. crnogorica, the BUCUR (2014) thinks that is most likely to be affiliated to Selliporella, based on the similarity to $S$. neocomiensis. We think that, beside other features, the shape of the primary branches of the investigated species is coherent with that of the genus Pseudoclypeina and is analogues to that of the type species $P$. cirici. A variety of branch shapes can often be seen in species of same genera (eg in the genus Dissocladella and Palaeodasycladus). As regards the calcitization of the skeleton, CONRAD \& VAROL (1990) showed that it can be different in species of the same genus (eg the genera of Clypeina and Salpingoporella). BERGER et al. (2003) showed, based on genetic research, that the genus Acicularia, by then distinct from the genus Acetabularia by the type of calcification, is genetically identical to it and thus represents a synonym. All this excludes the type of calcitization as a reliable generic characteristic, although it may serve at the species level.

Pseudoclypeina johnsoni (PRATURLON) n. comb.

Pls. XVII -XIX

Selected synonymy

1963 Triploporella neocomiensis n. sp. - RADOIČIĆ, 159-173, Pls. 1-5; syntypes: Pl. I, fig. 1; Pl. II, figs. 1-2; Pl. III, 42

1964 Diplopora johnsoni n. sp. - PRATURLON, 179-182, figs. 12-26

1972 Triploporella neocomiensis RADOIČIĆ - FENNINGER \& HOLZER, 123, Pl. 18, fig. 2

1972 Triploporella $\mathrm{cf}$. neocomiensis RADOIČIĆ - FOURCADE et al., 235, Pl. 2, figs. 1-4

1974 Triploporella neocomiensis RADOIČIĆ - JAFFREZO, 2830, Pl. II, figs. 11-12

1975 Triploporella neocomiensis RADOIČIĆ-RADOIČIĆ, 277; lectotype: RADOIČIĆ, 1963, Pl. I, fig. 1

1986 Triploporella neocomiensis RADOIČIĆ - LUPERTOSINNI \& MASSE, 37, 41, Pl. 3, figs. 4-5 
1988 Pseudoclypeina? neocomiensis RADOIČIĆ, 1963, n. comb. - GRANIER, 48, Pl. 41, figs. a-d

1992 Diplopora johnsoni PRATURLON - MANCINELLI, Pl. I, fig. 4, Pl. II, figs. 8-10

1993 Triploporella neocomiensis RADOIČIĆ - LUPERTOSINNI \& MASSE, Pl. 1, figs. 9-10

1999 Selliporella cf. neocomiensis RADOIČIĆ, 1963 - YILMAZ, 91, Pl. 3, fig. 50

2001 Selliporella neocomiensis (RADOIČIĆ) - SĂSĂRAN \& BUCUR, 197, Pl. 4, figs. 1-7

2003 Selliporella neocomiensis RADOIČIĆ, 1975 (non 1963), n. comb. - BUCUR \& SĂSĂRAN, 57 - 66, Pls. I-III

2005a Selliporella neocomiensis (RADOIČIĆ) - BUCUR \& SĂSĂRAN, 31, Pl. III, figs. 2-3 and Bucur \& SĂSĂRAN 2005b, p., fig.6J,M,N

2005b Selliporella neocomiensis (RADOIČIĆ) - BUCUR \& SĂSĂRAN, figs. 6J,M,N

2006 Pseudoclypeina? neocomiensis (RADOIČIĆ) - HUSINEC \& SOKAČ, 421, Fig. 3G, Fig. 4A

Dimensions in mm:

\begin{tabular}{lc}
\hline L $=$ & 30,74 \\
$D$ & $2,14-3,40$ \\
$d$ & $0,82-1,60$ \\
d/D & $0,320-0,450$ \\
h & $0,14-0,46$ \\
p & $0,10-0,15$ \\
p $^{\prime}$ & $0,06-0,20$ \\
I & $0,18-0,24$ \\
l' $^{\prime}$ & $0,40-0,50$ \\
w & $6-18(? 20)$ \\
w' $^{\prime}$ & $5-6(? 7)$ \\
w $^{\prime \prime}$ & $? 3-4$ \\
\hline
\end{tabular}

Description: A relatively large calcareous alga, with cylindrical skeleton, clearly articulated all along its length. Central cavity, only seldom completely preserved, occupies $30-45 \%$ of the entire diameter. (Pl. XVII, figs. 1 upper part, 3, 6; Pl. XVIII, figs. 1, 8; Pl. XIX, figs. 1, 4-5). Most frequently, it is secondarily widened, owing to destruction of the probably poorly calcified proximal ends of primary laterals (Pl. XVII, figs. 1 lower part, 2; Pl. XVIII, figs. 2-3; Pl. XIX, figs. 2, 7). In some sections, the central cavity has a slight widening at the level of whorls and narrowing between the whorls, which makes the inner surface gently undulating (Pl. XVIII fig. 5).

Bipartite laterals are arranged into distinctly and regularly well-spaced whorls. Each whorl corresponds to one article of the skeleton, formed by the amalgamation of individual calcareous sheets of tufts of neighbouring secondary laterals from the same whorl (Pl. XVII, figs. 1, 4, 6; Pl. XVIII, figs. 1-4, 8; Pl. XIX, figs. $2-4,6)$. Primary and secondary laterals are clearly distinguishable. The primaries, slightly inflated and approximately globular in shape, vary only negligibly (Pl. XVII, figs. 5-6; Pl. XVIII, figs. 2, 5; Pl. XIX, figs. 1, 5, 7). Each primary lateral bears a tuft of secondaries, which were, in sections illustrated in previous papers poorly defined, mostly interpreted as being trichophorous in shape. Each bundle of secondary laterals, grown out of an individual primary lateral, consists of 5-6, possibly 7-8, individual secondaries, undoubtedly visible in deeper tangential sections, cutting through their proximal parts (Pl. XVII, fig. 4; Pl. XVIII, figs. 2-4, 6-7; Pl. XIX, figs. 3, 6). Starting from their initial point of growth, going distally they are slightly inclined upwards or downwards. Generally of a phloiophorous shape, they slightly widen distally (Pl. XVII, figs. 5-6; Pl. XVIII, figs. 2-3; Pl. XIX, figs. 1, 4, 7). In some sections, ring-like constrictions of secondaries may be visible, though indistinctly, possibly indicating their articulation (Pl. XVII, figs. 5-6; Pl. XVIII, fig. 8; Pl. XIX, fig. 8). The outer ends of calcified tufts are typically eroded, thus making it impossible to gain a full insight into the distal ends of the secondaries. The large number of small pores in distal tangential sections, cutting through individual tufts (Pl. XIX, fig. 3; also RADOIČIĆ, 1963, Pl. 1, fig, 1 top; PRATURLON, 1964, figs. 12, 14 bottom), suggests the possible existence of tertiary laterals, yet to be undoubtedly proven. This possibility is also indicated in some of our sections, in which, in their outer marginal zone, possible traces of tertiaries can be discerned (Pl. XVII, fig. 7; Pl. XIX, fig. 7). Their origin can only be supposed by the existence of tiny tufts of short tertiaries. Thus the question of tertiary laterals remains open in the focus of future investigations of this interesting alga.

Stratigraphic position: Determination of the stratigraphic range of Pseudoclypeina johnsoni (PRATURLON) in Lower Cretaceous deposits of the coastal Dinarides in southern Croatia is based on discoveries of associated or superposed fossil assemblages in the investigated localities on Mt. Dinara and on the island of Mljet.

On Mt. Dinara, at the „Bravči dolac” locality, this species is accompanied by the dasyclad algae Salpingoporella annulata CAROZZI, Salpingoporella steinhauseri CONRAD et al., Falsolikanella campanensis (AZEMA \& JAFFREZO), Pseudoclypeina? crnogorica RADOIČIĆ, Clypeina marteli EMBERGER. Among the foraminifers, Varcorsella camposaurii (SARTONI \& CRESCENTI), and Varcorsella tenuis (VELIĆ \& GUŠIĆ) are the most frequent, accompanied by undetermined small foraminifers. Taken as a whole, the accompanying fossil assemblage at the Mt. Dinara locality, together with that in both the immediately over- and underlying deposits, indicates a stratigraphic age range of Upper Berriasian - Lower Valanginian.

The sample from the Mljet Island (Mlj-46) comes from a poorly fossiliferous interval, typical of continuous shallow water sedimentation on a carbonate platform. The stratigraphic position can only be intermediately defined. In the analysed column, the sample Mlj-46 is situated about $30 \mathrm{~m}$ below the first occurrence of Campanellula capuensis DE CASTRO, accompanied by rare sections of Falsolikanella danilovae (RADOIČIĆ) and Salpingoporella genevensis (CONRAD); immediately upwards, the algal assemblage gets richer, with typically Barremian species. Because Campanellula capuensis in this area is characteristic of a narrow zone (taxon-range zone, VELIĆ, 1988, 2007) transitional from the Late Hauterivian to the Barremian and because in the interval between the Mlj-46 sample and the beginning of the above mentioned zone Salpingoporella annulata gradually disappears, the stratigraphic position of Pseudoclypeina johnsoni on the Mljet locality can be ascribed to a Middle Hauterivian level.

\section{ACKNOWLEDGEMENT}

It is our pleasure to thank most cordially our colleagues Ivan GALOVIĆ, Ivo VELIĆ, Božo PRTOLJAN and Igor VLAHOVIĆ, for field work and collecting the copious material used in this paper. Moreover, we thank Ivo Velić for the determination of foraminiferal assemblages and explanation of their stratigraphic ranges. Thanks to Ivan GUŠIĆ for translation and Judith Mc- 
KENZIE for the language review of this paper. This study was supported by the Ministry of Science, Education and Sports of the Republic of Croatia through projects 181-1811096-1093, 1811951126-1134, and 195-1953068-0242.

We especially express our gratitude to the reviewers Marc CONRAD and Ioan I. BUCUR for the effort, useful corrections and suggestions which have contributed to our work. In the interest of the protection of the personal attitude of Ion I. Bucur we must emphasize his opposition to our opinion and arguments for the assignation of the species Triploporella neocomiensis Radoičić to the genus Pseudoclypeina. The reviewer remains of the opinion stated in his previously published papers that we, for the reasons explained in the text, could not adopt.

\section{SUPPLEMENT}

\section{Selliporella donzellii \\ SARTONI \& CRESCENTI var. gallaeformis \\ (RADOIČIĆ)}

n. comb., n. var.

Dimensions in mm:

\begin{tabular}{cc}
\hline$D$ & $3,20-5,00$ \\
$d$ & $? 1,58$ \\
$p$ & 0,24 \\
$p^{\prime}$ & $0,40-0,52$ \\
& $0,20-0,40$ \\
I & $0,80-1,20$ \\
\hline
\end{tabular}

\section{Selliporella cornutoformis n. sp.}

\section{Dimensions in mm:}

\begin{tabular}{lc}
\hline$L=$ & 19,4 \\
$D$ & $2,40-4,20$ \\
$d$ & $0,48-1,15$ \\
$d / D$ & $0,200-0,400$ \\
$D^{\prime}$ & $0,80-1,64$ \\
$d$ & $0,45-0,98$ \\
$d^{\prime} / D^{\prime}$ & $0,500-0,800$ \\
h & $0,98-2,38$ \\
p & $0,10-0,24$ \\
$p^{\prime}$ & $0,14-0,24$ \\
l & $0,15-0,20$ \\
l & $0,60-1,94$ \\
w & $15-25$ \\
w $^{\prime}$ & $1-3 ? 5$ \\
\hline
\end{tabular}

\section{REFERENCES}

BARATTOLO, F., DE CASTRO, P. \& RADOIČIĆ, R. (1992): The genus Selliporella SARTONI \& CRESCENTI 1963 (Chlorophyta, Dasycladales) and its type-species.Mem. Soc. Geol. Ital. 41(1988), 593-604, Roma.

BASSOULLET, J.-P., BERNIER, P., CONRAD, M.A., DELOFFRE, R. \& JAFFREZO, M. (1978): Les Algues Dasycladales du Jurassique et du Crétacé.- Géobios, Mémoire special 2, 330 p., Lyon.

BERGER, S., FETTWEISS, U., GLEISSBERG, S., LIDDLE, L., RICHTER, U., SAWITZKY, H. \& ZUCCARELLO, G. (2003): 18S rDNA phylogeny and evolution of cap development in Polyphysaceae (formerly Acetabulariaceae; Dasycladales, Chlorophyta).- Phycologia, 42/5, 506-561. doi: 10.2216/i0031-8884-42-5-506.1

BUCUR I.I. (2014): A new dasycladalean alga from the Lower Cretaceous of the Eastern Carpathians (Romania): Andreiella rajkae nov. gen., nov. sp..--Facies, 60, 217-228. doi: 10.1007/s10347-013-0375-z

BUCUR, I.I. \& SĂSĂRAN, E. (2003): Selliporella neocomiensis RADOIĆIČ, 1975 (non 1963), nov. comb., a Lower Cretaceous dasyclad alga from the Tethyan realm.-Acta Micropal. Sinica, 20, 57-66.

BUCUR, I.I. \& SĂSĂRAN, E. (2005a): Micropaleontological assemblages from the Upper Jurassic-Lower Creataceous deposits of Trascău Mountains and their biostratigraphic significance.- Acta Pal. Roman., 5, 27-38.

BUCUR, I.I. \& SĂSĂRAN, E. (2005b): Relationship between algae and environment: an Early Cretaceous case study, Trascău Mountains, Romania.- Facies, 51, 274-286. doi: 10.1007/s10347-005-0001-9

CARRAS, N., CONRAD, M.A. \& RADOIČIĆ, R. (2006): Salpingoporella, a common genus of Mesozoic Dasycladales (calcareous green algae).- Revue de Paléobiologie, 25/2, 457-517, Genève.

CONRAD, M.A. \& VAROL, B. (1990): Cylindroporella taurica n.sp., urges to rewiew different patterns of calcification in the Mesozoic Dasycladales (Green Algea).- Arch. Sci. Geneve, 43, 193-214.

DE CASTRO, P. (1997): An approach to thin-section study of fossil Dasycladales (Introduzione allo studio in sezione sottile delle Dasicladali fossili).- Quad. Accad. Pontaniana Napoli, 22, $261 \mathrm{p}$.

GRANIER, B. (1988): Algues Chlorophyceae du Jurassique terminal et du Crétacé inférieur en Alicante.- Mediterranea, Serie Est. Geol., 5 (1986), 5-96, Alicante.
GRANIER, B. \& DELOFFRE, R. (1994): Inventaire critique de Algues Dasycladales fossiles. Ilo partie - Les Algues Dasycladales du Jurassique et du Crétacé.- Rev. Paléobiol., 12/1 (1993), 19-65, Genève.

HUSINEC, A. \& SOKAČ, B. (2006): Early Cretaceous benthic associations (foraminifera and calcareous algae) of a shallow tropical-water platform environment (Mljet Island, southern Croatia).- Cretac. Res., 27/3, 418-441. doi: 10.1016/j.cretres.2005.07.008

JAFFREZO, M. (1974): Les algues calcaires du Jurassique supérieur et du Crétacé inférieur des Corbières (2ème parte).- Rev. Micropal., 17/1, 23-32, paris.

LUPERTO-SINNI, E. \& MASSE, J.-P. (1986): Données nouvelles sur la stratigraphie des calcaires de plate-forme du Crétacé inférieur du Gargano (Italie meridionale).- Riv. It. Paleont. Strat., 92/1, 33-66, Milano.

LUPERTO-SINNI, E. \& MASSE, J.-P. (1993): The Early Cretaceous Dasycladales from the Apulia region (southern Italy) : biostratigraphic distribution and paleobiogeographic significance.- In: BARATTOLO, F., DE CASTRO, P. \& PARENTE, M. (eds). Studies on Fossil Benthic Algae. Proceedings of the 5th International Symposium on Fossil Algae (Capri, 7-12 April, 1991).- Boll. Soc. Paleont. Ital., Spec. Vol. 1, 295-309.

MANCINELLI, A. (1992): Distribuzione delle Dasicladali (alghe verdi) nei sedimenti del Cretaceo inferiore in facies di piattaforma carbonatica dell Appennino centro-meridionale (Lazio e Abruzzo).- Studi Geol. Camerti, 12, 7-29, Camerino.

NIKLER, L. \& SOKAČ, B. (1967): Fosilne Dasycladaceae gornje jure Velebita i sjeverozapadne Velike Kapele (Fossil Dasycladaceae from Upper Jurassic of the Mount Velebit and the NW part of the mount Velika Kapela).- Rad Jugosl. akad. znan. umjet., 345, 101-134, Zagreb.

NIKLER, L. \& SOKAČ, B. (1968): Biostratigraphy of the Jurassic of Velebit (Croatia) (Biostratigrafija jure Velebita).- Geol. vjesnik, 21 (1967), 161-176, Zagreb.

PRATURLON, A. (1964): Calcareous algae from Jurassic-Cretaceous limestone of central Apennines (Southern Latium - Abruzzi).- Geol. Romana, 3, 171-202.

RADOIČIĆ, R. (1963): Triploporella neocomiensis spec. nov. iz slojeva valendis-otriva Crne Gore (Triploporella neocomiensis spec. nov. des couches valanginiennes-hautiriviennes du Montenegro).- Vesnik, A, 21, 139-144, Beograd.

RADOIČIĆ, R. (1965): Teutloporella gallaeformis spec. nov. iz jure Spoljašnjih Dinarida (Teutloporella gallaeformis spec. nov. du Jurassique des Dinarides externes).- Geol. Glasnik, 4, 219-226, Titograd.

RADOIČIĆ, R. (1966): Microfacies du Jurassique des Dinarides externes de la Yougoslavie.- Geologija, 9, 5-376, Ljubljana.

RADOIČIĆ, R. (1970) Deux pseudoclypéines du Jurassique supérieur des Dinarides yougoslaves.- Rev Micropal, 13/2, 115-121.

RADOIČIĆ, R. (1975): Linoporella buseri sp. nov. from the Liassic of the Julian Alps (a preliminary report). Bull. Sci. Cons. Acad. Sci. Arts RSF Yougosl.-Sect. A: Sci. Nat., Techn. Méd., 20, 277-278, Zagreb.

RADOIČIĆ, R., CARRAS, N. \& CONRAD, M.A. (2013): Pseudoclypeina? crnogorica RADOIČIĆ, 1972. - Stratigraphic revision and taxonomic note on a little known dasycladalean alga from Montenegro.- Geol. anali Balkan. poluostrva, 74, 25-37, Beograd.

SARTONI, S. \& CRESCENTI, U. (1962): Ricerche biostratigrafiche nel Mesozoico dell'Appennino meridionale.- Giorn. Geol., Ser. 2, 29, 162-302.

SĂSĂRAN, E. \& BUCUR, I.I. (2001): Upper Jurassic- Lower Crelaceous microbolites and calcareos algae from Strambrk-like limestones in Cheile Turzii area.- In: BUCUR, I.I. \& SĂSĂRAN, E. (eds): Algae and carbonate platforms in western part of Romania. Field-trip guidebook (4th Meeting of IFAA, August 29-September 5, 2001), 191-207. Cluj University Press, Cluj-Napoca.

SOKAČ, B. (1992): Two New Species of Calcareous Algae (Dasycladaceae) from the Upper Dogger of Southern Dalmatia (Croatia) (Dvije nove vrste vapnenačkih alga (Dasycladaceae) iz gornjeg dogera južne Dalmacije (Hrvatska)).- Geol. Croatica, 45, 15-24, Zagreb. doi: 10.4154/GC.1992.02

SOKAČ, B. \& VELIĆ, I. (1978): Redescription of the genus Selliporella (Calcareous algae, Dasycladaceae) (Ponovni opis roda Selliporella (vapnenačke alge, Dasycladaceae)).- Geol. vjesnik, 30/1, 225-242, Zagreb.

SOKAČ, B. \& VELIĆ, I. (2007): Stop 9 - Middle Jurassic with Selliporella donzellii.- In: GRGASOVIĆ, T. \& VLAHOVIĆ, I. (ed.): 9th International Symposium on Fossil Algae, Field-Trip Guidebook and Abstracts. Hrvatski geološki institut, 63-67, Zagreb.

VELIĆ, I. (1988). Lower Cretaceous benthic foraminiferal biostratigraphy of the shallow water carbonates of the Dinarides.- Rev. Paléobiol., Spec. Vol. 2 (Benthos '86), 467475 .

VELIĆ, I. (2005): „Misterij dogera”: foraminiferske zajednice i stratigrafska raščlamba srednjojurskih naslaga u krškim Dinaridima (Jadranska karbonatna platforma) (Benthic foraminifera assemblages and stratigraphic subdivision of the Middle Jurassic in Karst Dinarides, Adriatic Carbonate Platform).- In: VELIĆ, I., VLAHOVIĆ, I. \& BIONDIĆ, R. (eds.): 3. Hrvatski geološki kongres (3rd Croatian Geological Congress), Opatija, 2005, Knjiga sažetaka (Abstracts book), Hrvatski geološki institut (Croatian Geological Survey), 159-160.

VELIĆ, I. (2007): Stratigraphy and palaeobiogeography of the Mesozoic benthic foraminifers on the Adriatic carbonate platform (Karst Dinarides, Croatia).- Geol. Croat., 60/1, 1-113. doi: 10.4154/GC.2007.01

YILMAZ, İ. Ö. (1999): Taxonomic and paleogeographic approaches to the dasyclad algae in the Upper Jurassic (Kimmeridgian) - Upper Cretaceous (Cenomanian) peritidal carbonates of the Fele (Yassıbel) area (Western Taurides, Turkey).- Turkish Journ. Earth Sci., 8, 81-101. 
Plate I

1-9 Selliporella donzellii SARTONI \& CRESCENTI var. donzellii (basal part of the thallus).

1,3,5 Oblique-tangential sections - demonstrating the basal part of the thallus with undivided piriferous laterals. Slides: fig. 1, 0-79/1; fig. 3, 0-79/216; fig. 5, $0-79 / 185, \times 22$.

2 Part of a tangential section - demonstrating distally individualized sheets of undivided laterals. Slide: 0-79/75, x22.

$4 \quad$ Longitudinal section. Slide: $0-79 / 297, \times 22$

6 Longitudinal section - demonstrates the lower part of the thallus with a transition from undivided to divided laterals. The gradual increase in the outer diameter (transition to claviform thallus, complete central cavity in the lower part and secondary extended in the upper part). Slide: 0-79/61, x12,5.

7-9 Oblique sections - undivided piriferous laterals, with differently inclined growth and variable diameter. Slides: fig. 7, 0-79/75; fig. 8, 0-79/79; fig. 9, 0-79/38, x22. 

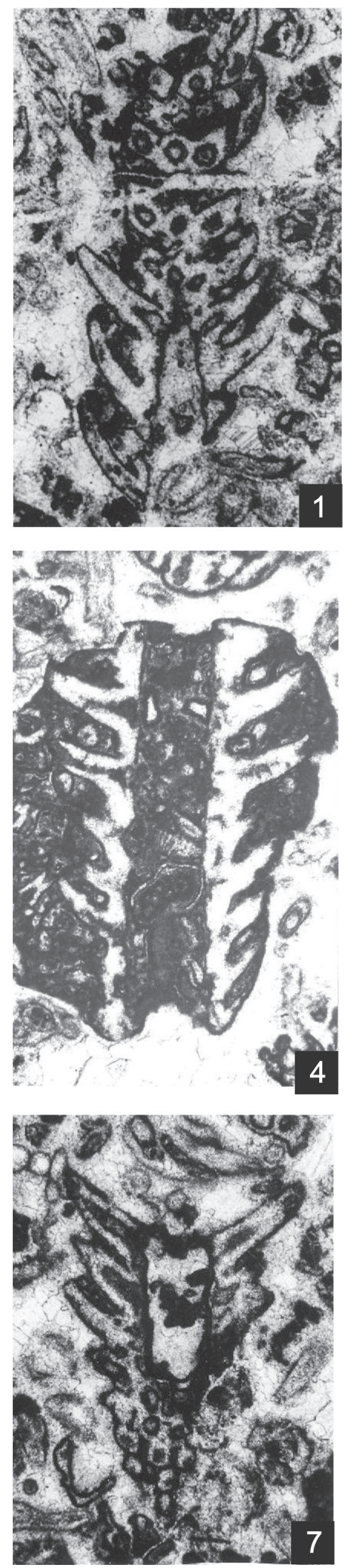

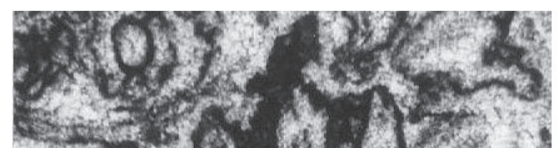

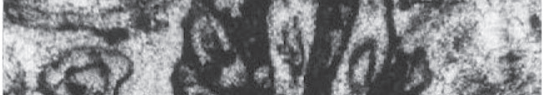

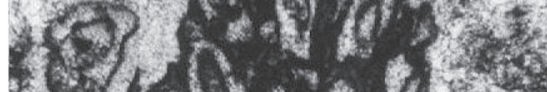

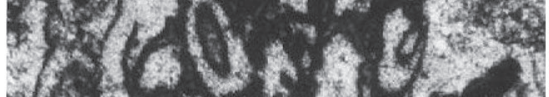

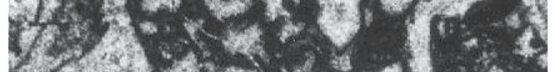
(4) $(2), \sin ^{3}, 3$

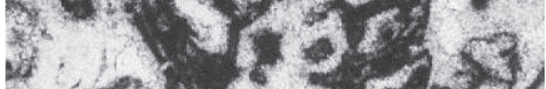

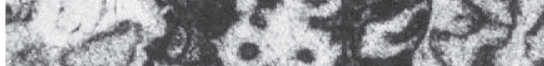
$3 \cos (5+5), y$

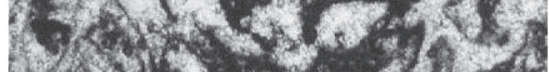
$01,19-2,+3 \%$

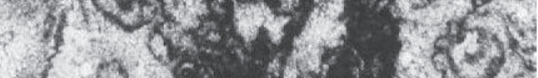

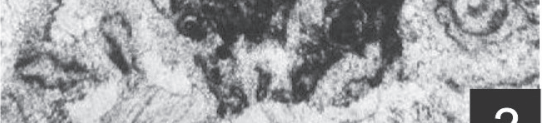

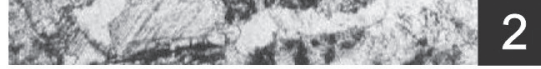
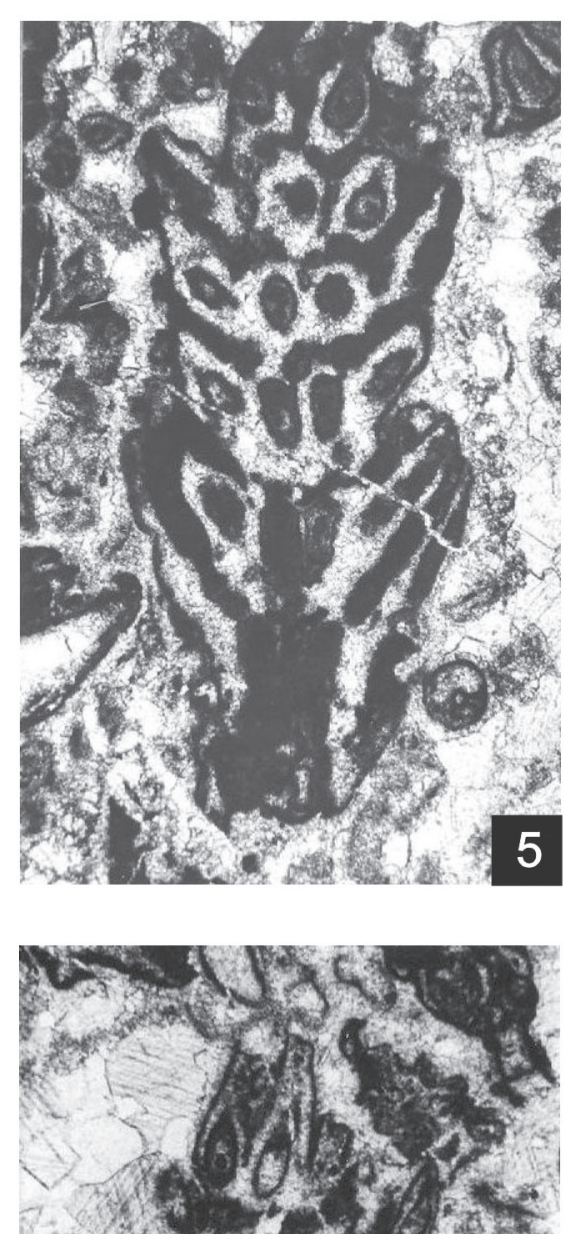

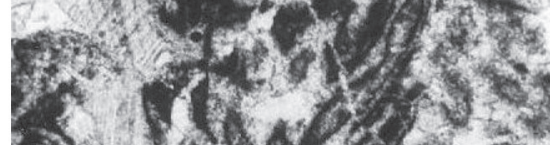

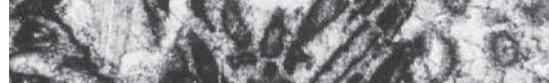

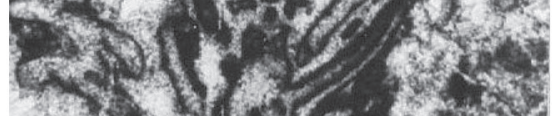
(a) $x^{2}$, \&Ech (2) 1 or $\frac{23}{8}$
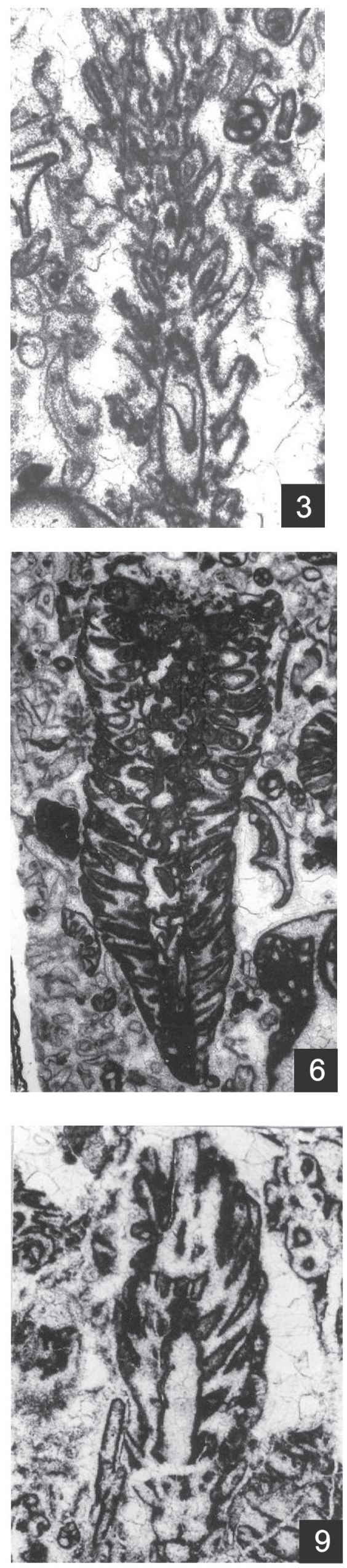
Plate II

1-9 Selliporella donzellii SARTONI \& CRESCENTI var. donzellii (basal part of the thallus).

1 Longitudinal-tangential section. Slide: 0-79/165, x22.

2-9 Oblique and transverse-oblique sections. Fig. 6a, Selliporella donzellii SARTONI \& CRESCENTI var. gallaeformis (RADOIČIĆ). Slides: fig. 2, 0-79/90, x22; fig. 3, 0-79/29, x34; fig. 4, 0-79/202, x22; fig. 5,0-79/185, x14; fig. 6, 0-79/125, x14; fig. 7, 0-79/94, x22; fig. 8, 0-79/150, x22; fig. 9, 0-79/26, x22 


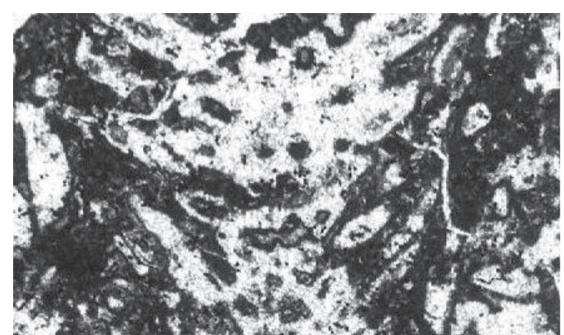

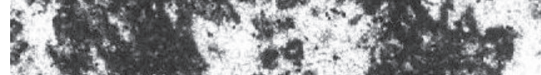

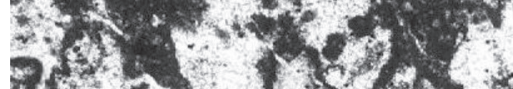

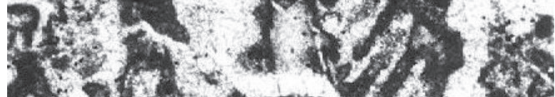
$601 \times 32$

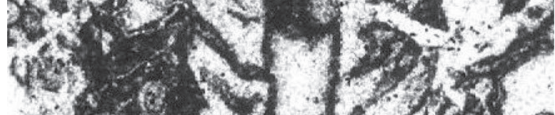

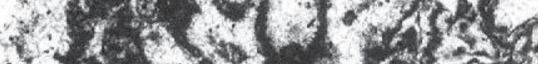

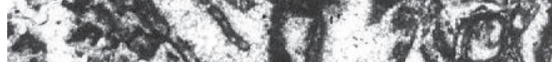

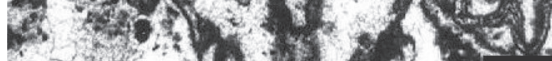

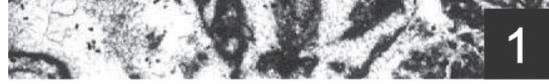
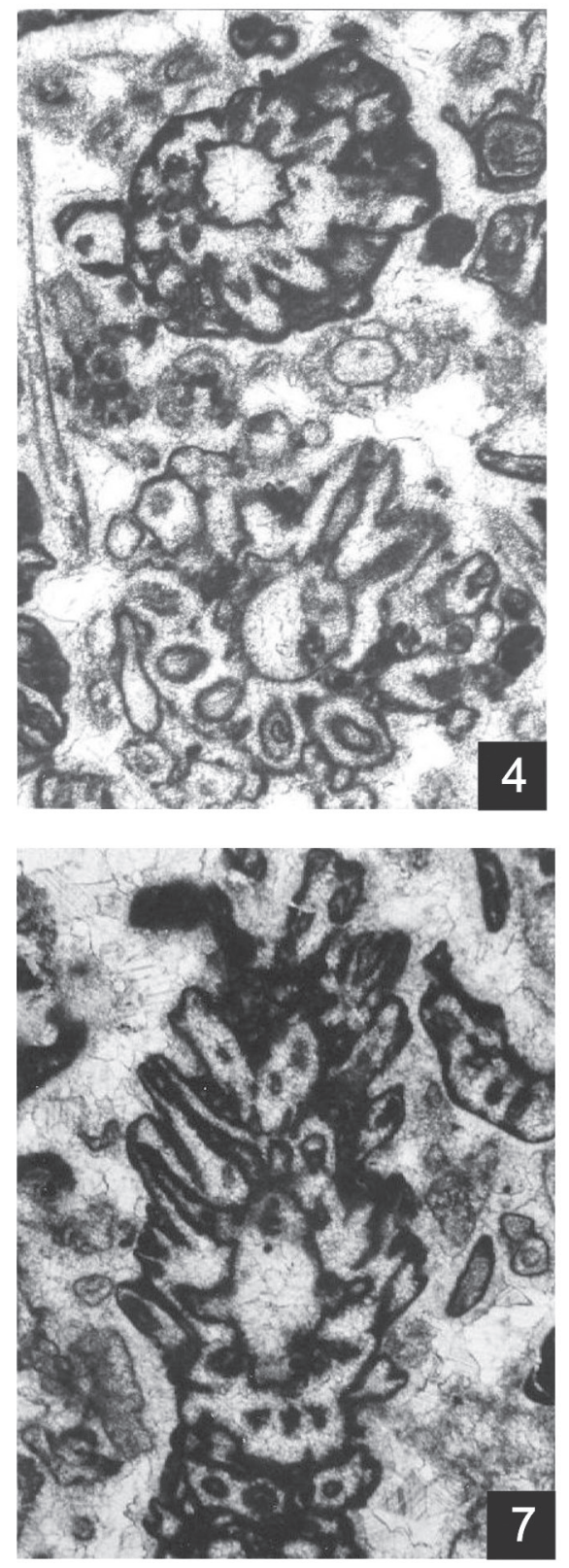
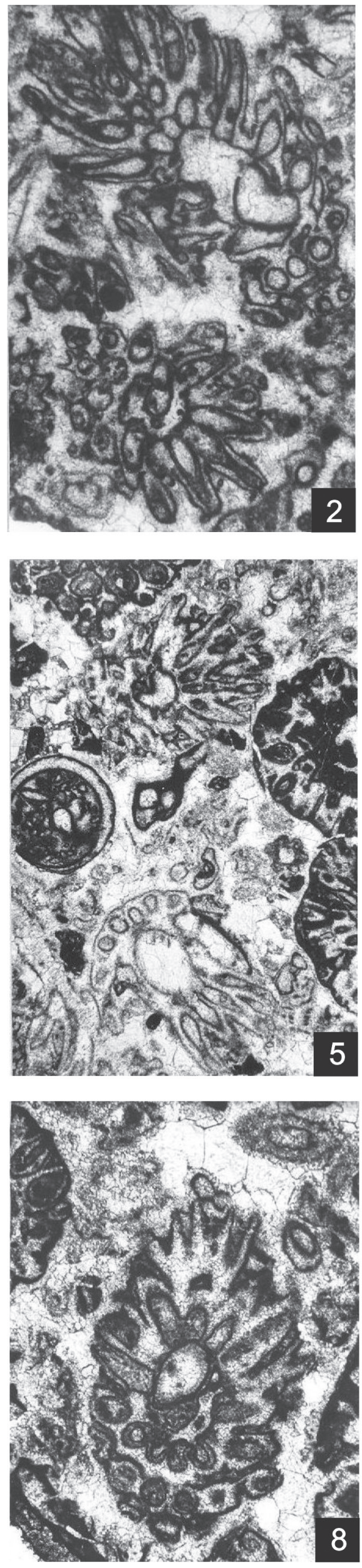
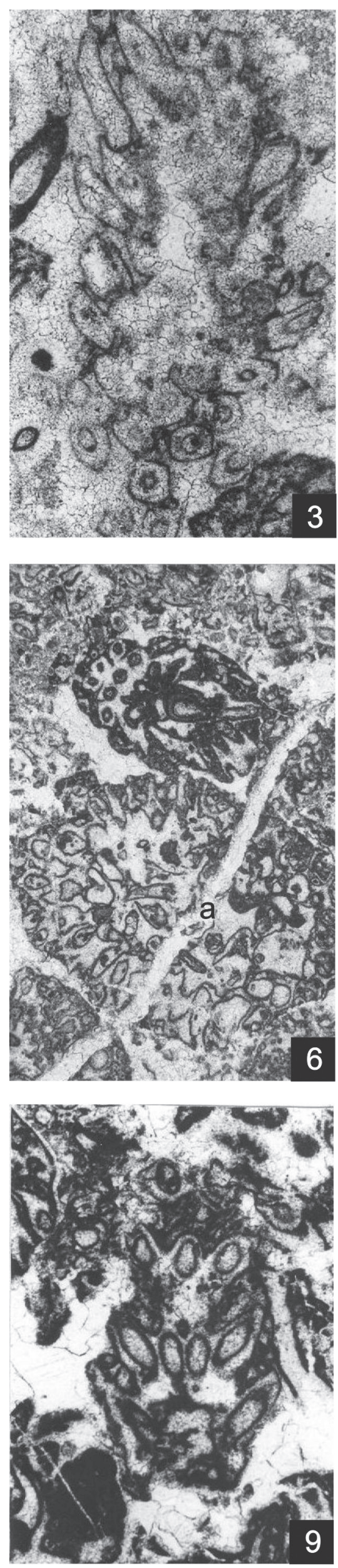
Plate III

1-14 Selliporella donzellii SARTONI \& CRESCENTI var. donzellii (basal part of the thallus).

13a Selliporella donzellii SARTONI \& CRESCENTI var. gallaeformis (RADOIČIĆ) n. comb., n. var.

1-2 Transverse sections - sections of undivided laterals with distally individualized sheets. Slides: fig. 1, 0-79/72, x34; fig. 2, 0-79/73; x34.

3 Transverse-oblique section - demonstrates a section of three successive whorls of undivided laterals with distally individualized sheets. Slides: 0-79/86, $\mathrm{x} 22$.

4-5 Oblique sections - undivided laterals with a more or less pronounced piriferous shape. Slides: fig. 4, 0-79/52, x34; fig. 5, 0-79/15, x22.

6-10 Transverse sections - demonstrateing a variable number of laterals in the whorl. Slides: fig. 6, 0-79/60, x22; fig. 7, 0-79/29, x34; fig. 8, 0-79/26, x25; fig. 9, $0-79 / 57, \times 25$; fig. 10, 0-79/186, x25.

11 Tangential section of the proximal and distal parts of whorls of undivided laterals. Slide: 0-79/59, x12,5.

12-14 Different sections of lower and upper parts of the thallus with undivided and divided laterals. Slides: fig. 12, 0-79/79; fig. 13, 0-79/197; fig. 14, 0-79/26; x12,5. 

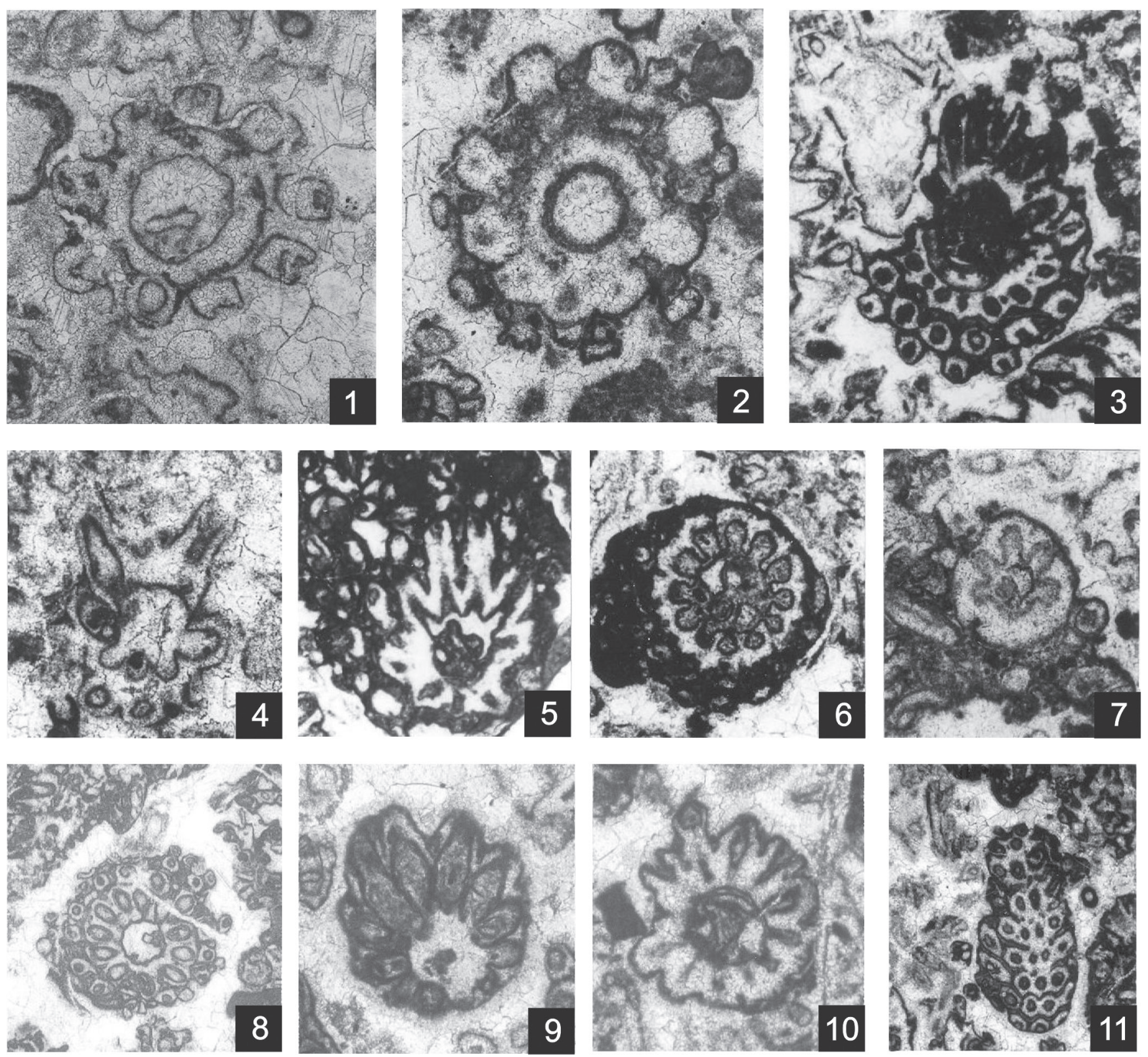

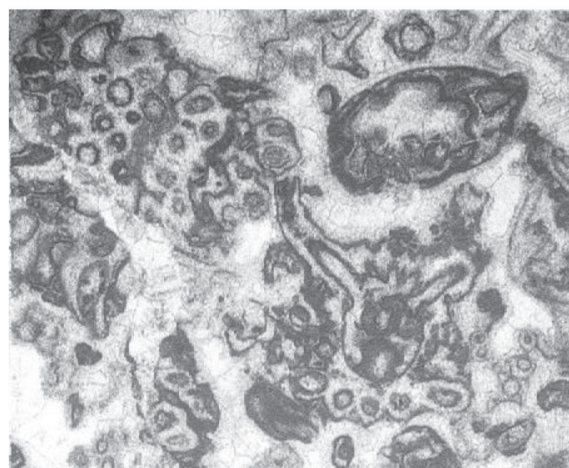

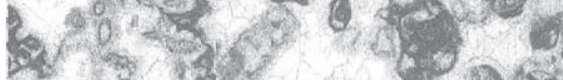

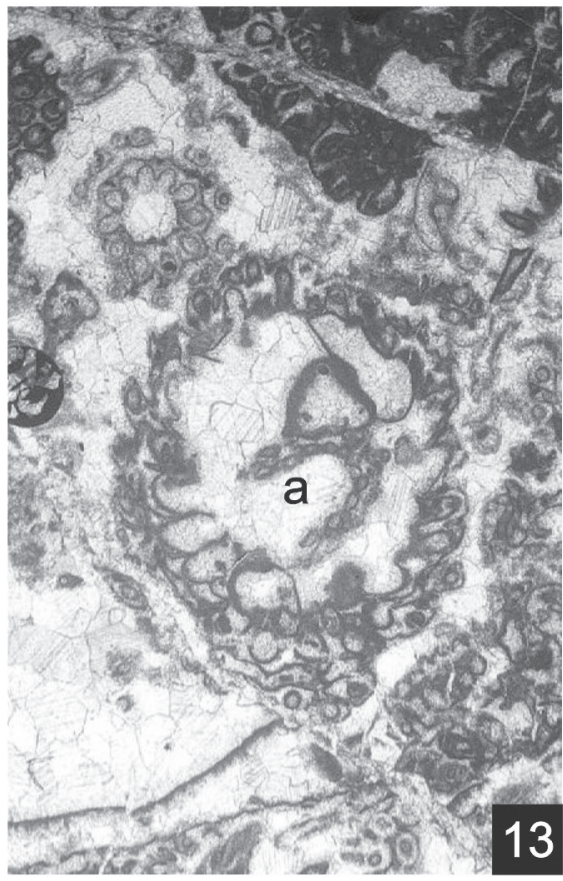

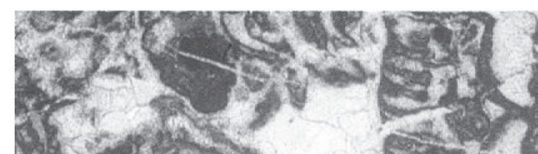

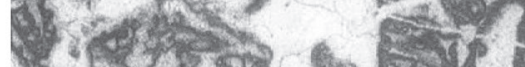

- hases an:

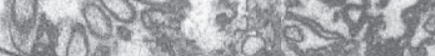

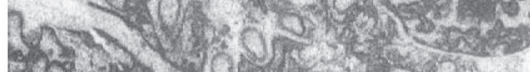

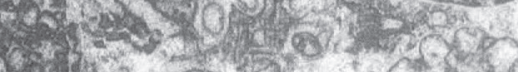

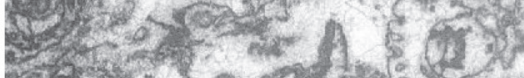

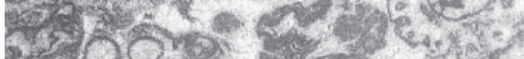
31000 , tectal of

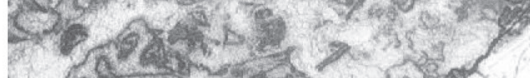

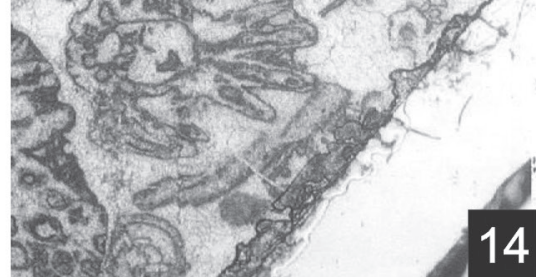




\section{Plate IV}

1-11 Selliporella donzellii SARTONI \& CRESCENTI var. donzellii

1 Longitudinal section demonstrates a transition from the lower part of the thallus with undivided laterals to the upper part with divided laterals, showing an evident increase in the height of articles. Slide: 0-79/112, x17

2 Oblique section demonstrates a part of the thallus with a transition from the whorls with undivided laterals to the whorls with divided laterals. Slide: 0-79/1, x22

3-6 More or less oblique sections of the middle part of the thallus with poorly visible primary laterals of tubular shape or slightly inflated proximally. Secondary laterals approximately equidimensional. Slides: fig. 3, 0-79/24; fig. 4, 0-79/214; fig. 5, 0-79/91; fig. 6, 0-79/206; x12,5

8 Oblique-longitudinal section demonstrates the transition from the poorly developed primary laterals of the complete central cavity in the visibly swollen laterals of secondary extended central cavity. Slide: 0-79/22; x12,5

7,9-11 Transverse sections of the middle part of the thallus with poorly developed primary laterals of the complete central cavity. Slides: fig. 7, 0-79/172; fig. 9, 0-79/70; fig. 10, 0-79/150; fig. 11, 0-79/214; x12,5 

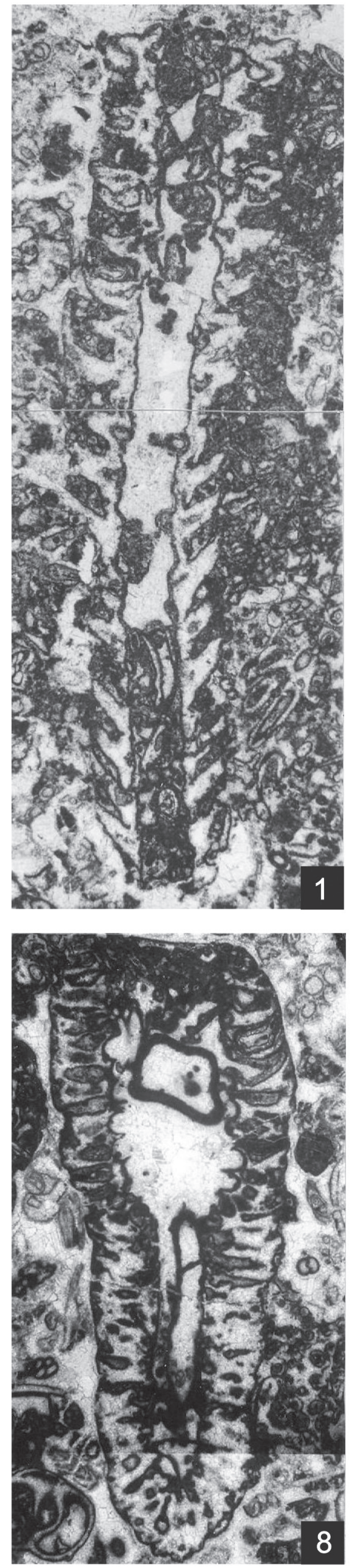

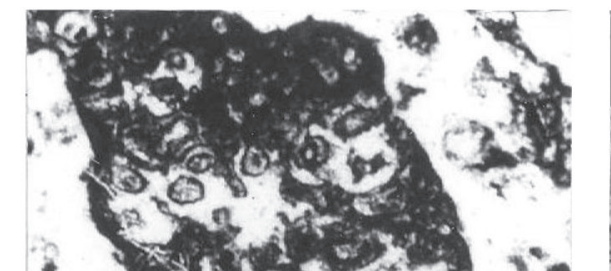

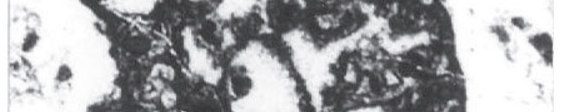

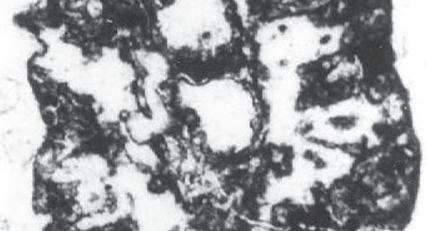

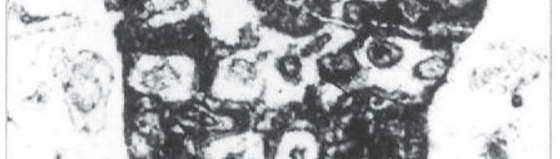
3 bo

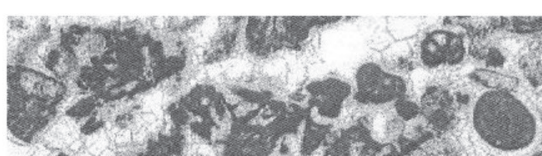

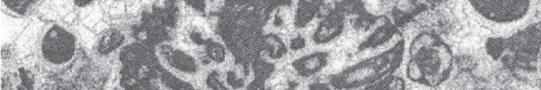

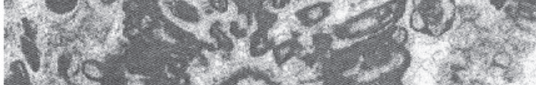

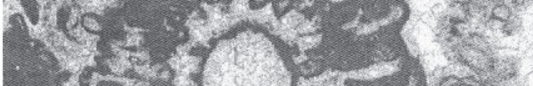

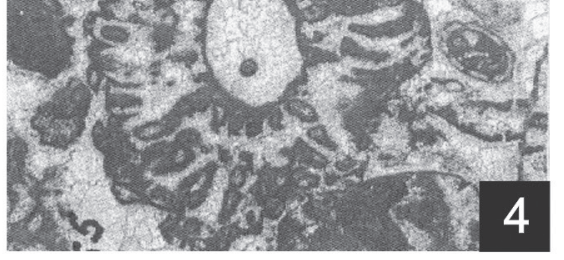

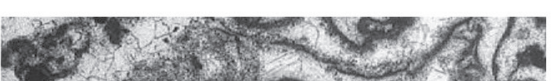
10.6.

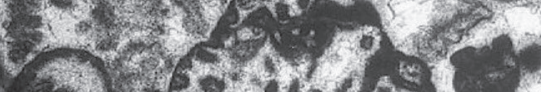

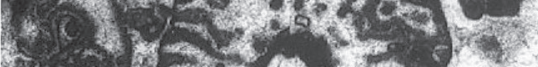

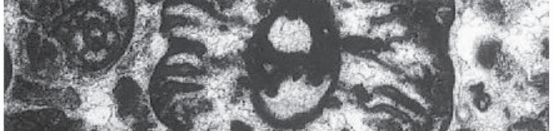

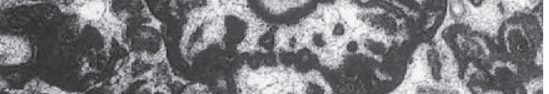

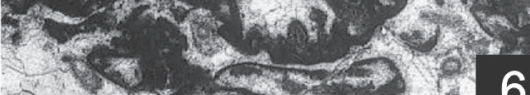

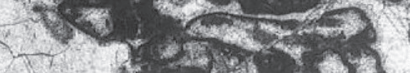

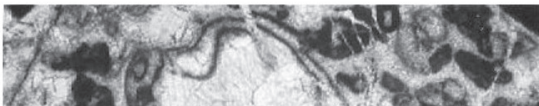

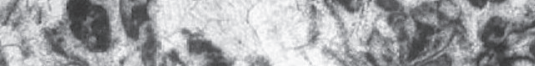

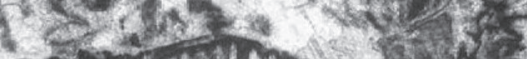

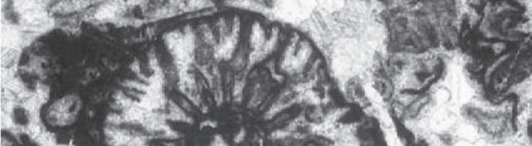

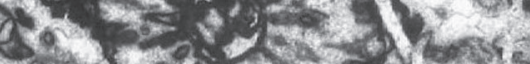

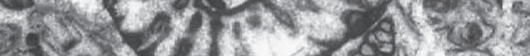
H.)

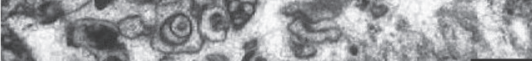

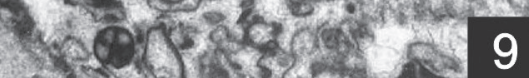
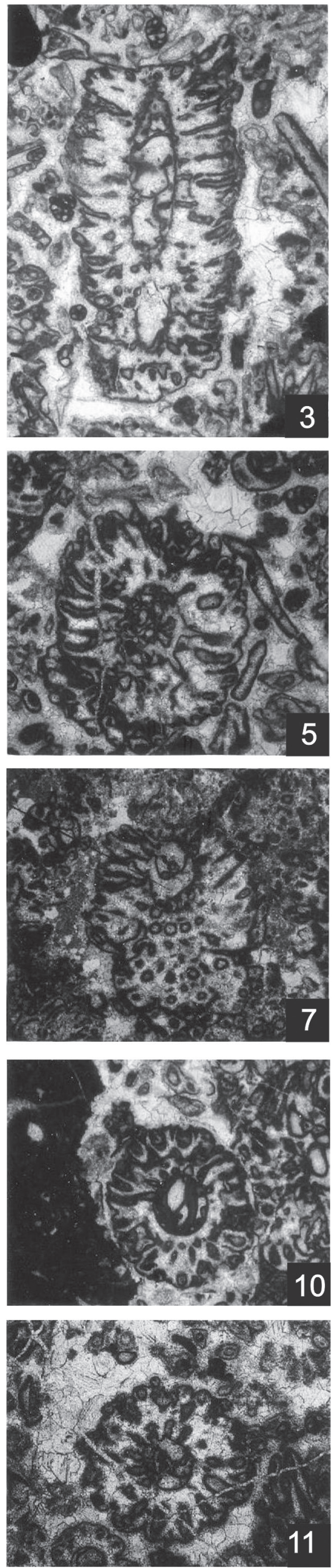
Plate V

1-6 Selliporella donzellii SARTONI \& CRESCENTI var. donzellii

1 Longitudinal-slightly oblique section. Lower part of the thallus with undivided laterals of the complete central cavity give rise to the upper part with proximally connected large primary laterals of secondary extended central cavity. Slides: 0-9/65, x12,5.

$2 \quad$ Longitudinal-oblique section demonstrates a transition to a slightly claviform shape with enlargement of the primary laterals in the upper part through proximal intercommunication of neighbouring laterals alongside a secondary extension of the central cavity. Slide: 0-79/90, x17.

3 Oblique section. Rare occurrence of branching of secondary laterals - arrow. Slide: 0-79/208, x22.

4 Transverse, slightly oblique section. Slide: 0-79/141, x12,5

5 Tangential-longitudinal section. Pronounced articulation of the lower part of the thallus making the transition to the upper part with divided large primary laterals and reduced annulation of the thallus. Slide: 0-79/106. x14.

6 Oblique section. Oblique irregular primary laterals with proximally partly visible intercommunication. Slide: 0-79/85, x12,5. 

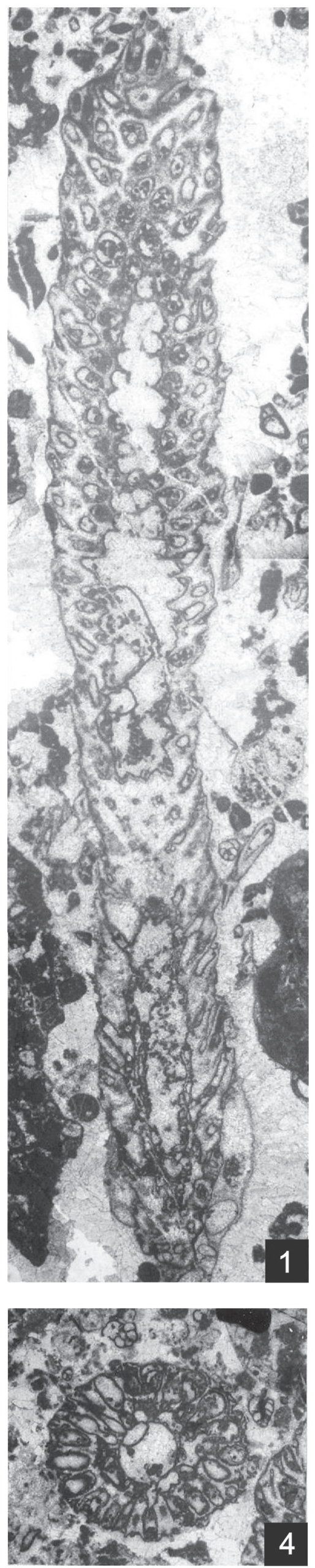
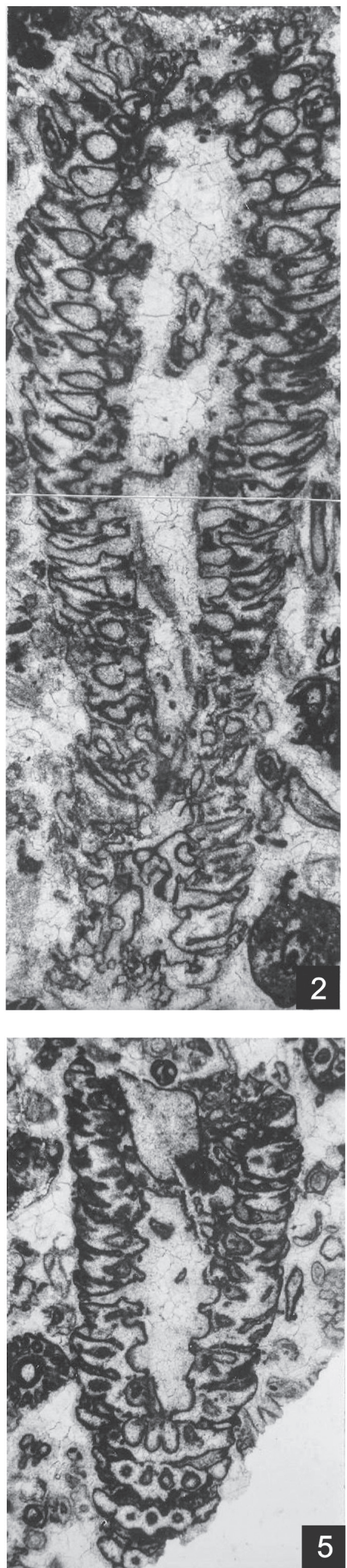

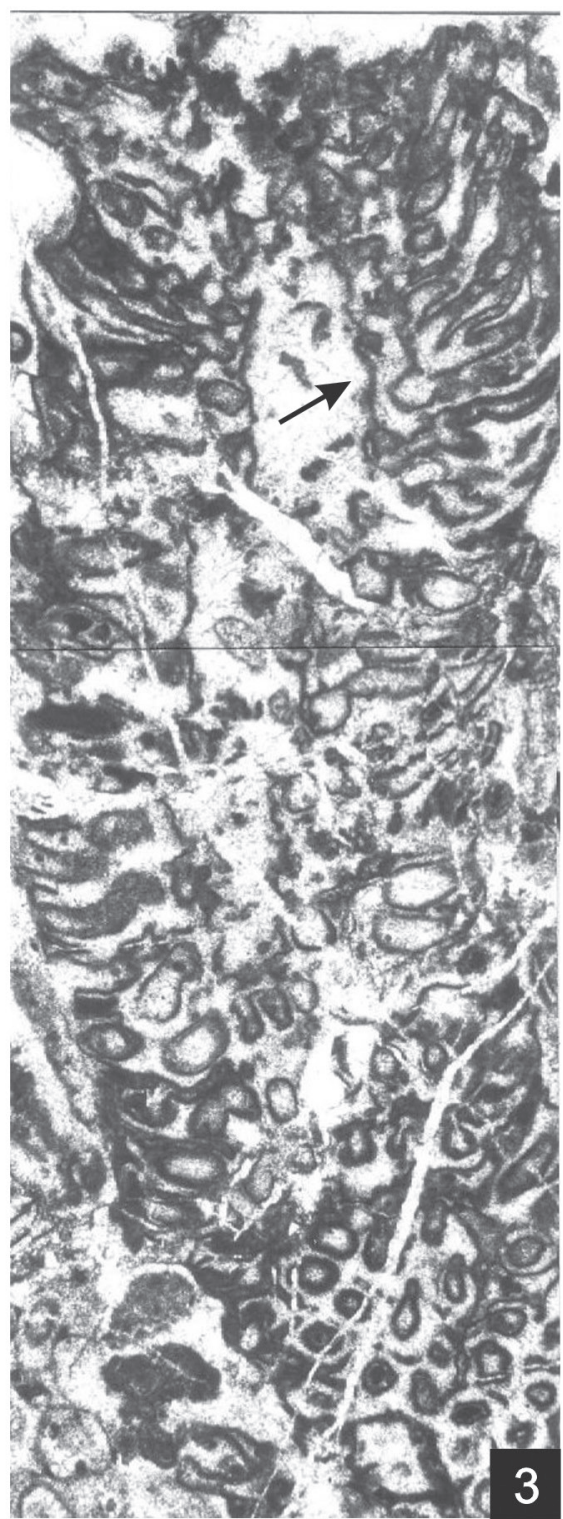

now

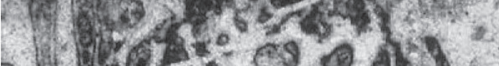

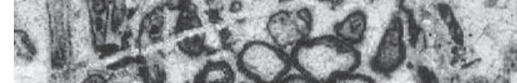

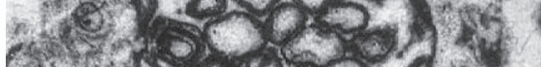

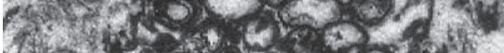

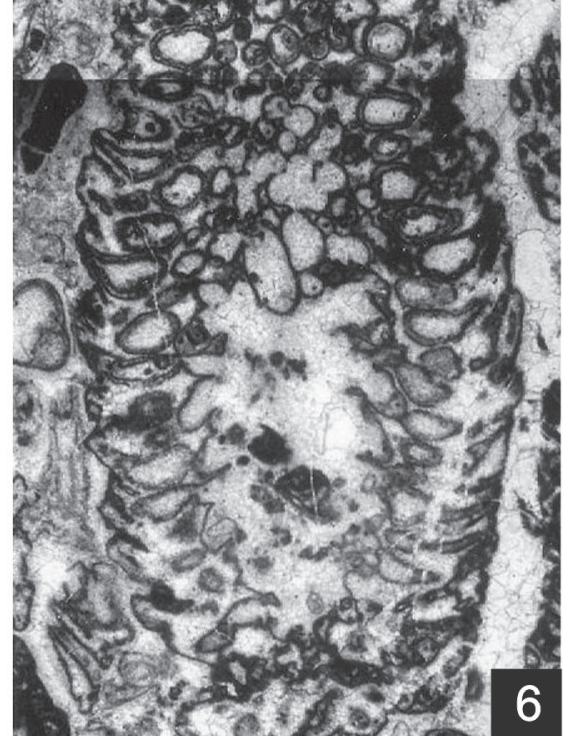




\section{Plate VI}

1-8 Selliporella donzellii SARTONI \& CRESCENTI. var. donzellii

1 Tangential-oblique section. The central part of the image shows the lateral compression of the primary laterals. Slide: 0-79/89, x17.

2 Oblique-tangential section. Relatively regularly inflated primary laterals. Slide: 0-79/190, x14.

3,5 Oblique sections. Slides: fig. 3, 0-79/73, x14; fig. 5, 0-79/35, x12,5

4,7 Transverse sections. Slides: fig. 4, 0-79/33; fig. 7, 0-79/47, x12,5

6 Longitudinal section. Transition from cylindrical to a slightly claviform part of the thallium with pronounced enlargement of the primary and secondary laterals. Slide: 0-79/115, x14.

8 Oblique-tangential section. The transition from the highly articulated part of the thallus to the part of visible but reduced annulation. Slides: 0-79/199, $\mathrm{x} 12,5$. 

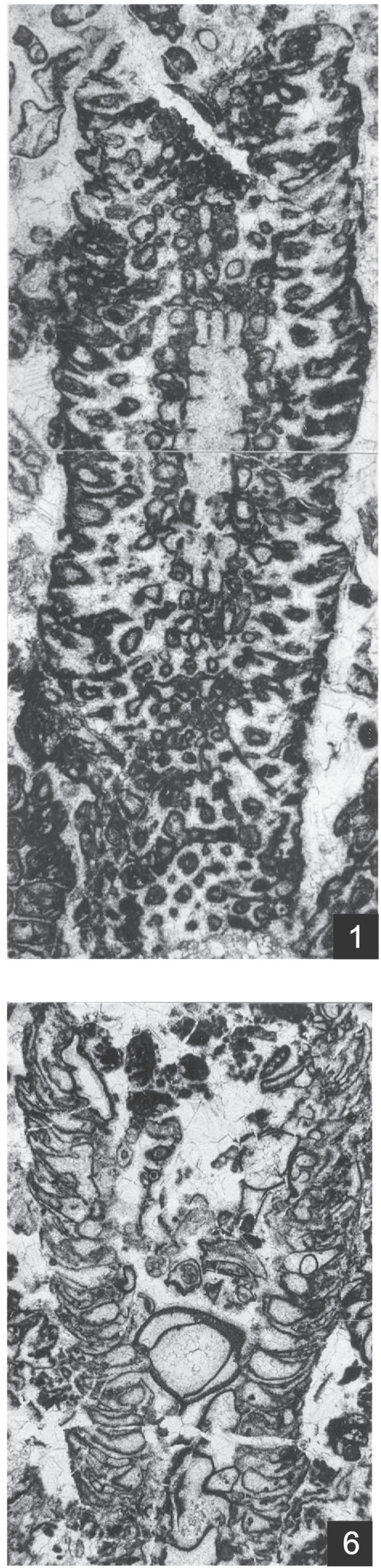

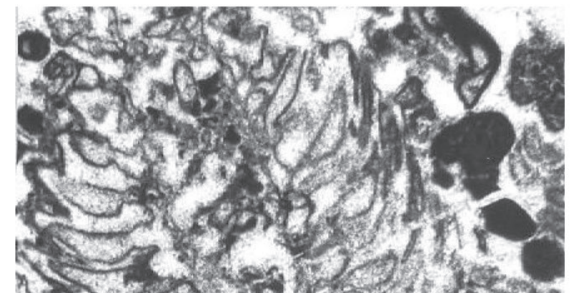

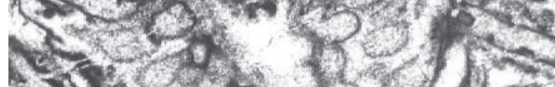
$N x^{2}+335 / 4$ 2.th $-2,395$. Wy 2350 , o

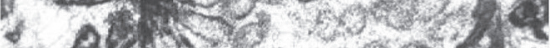
- Plin was $1 x^{3}=0$.

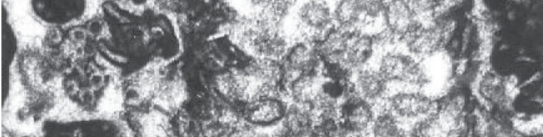

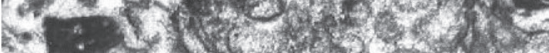

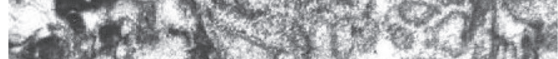
5.3 .

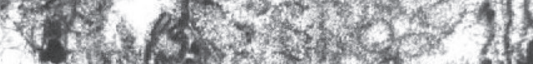

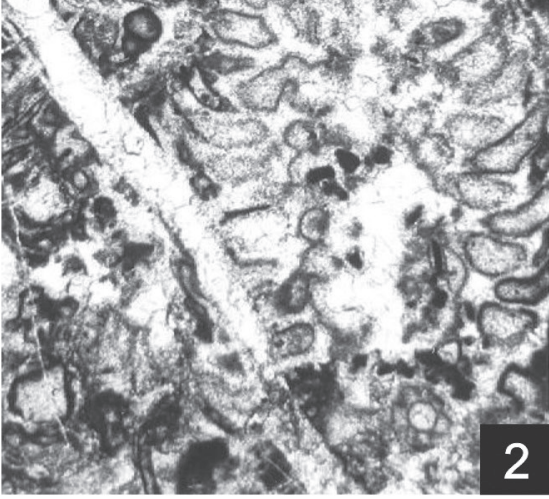
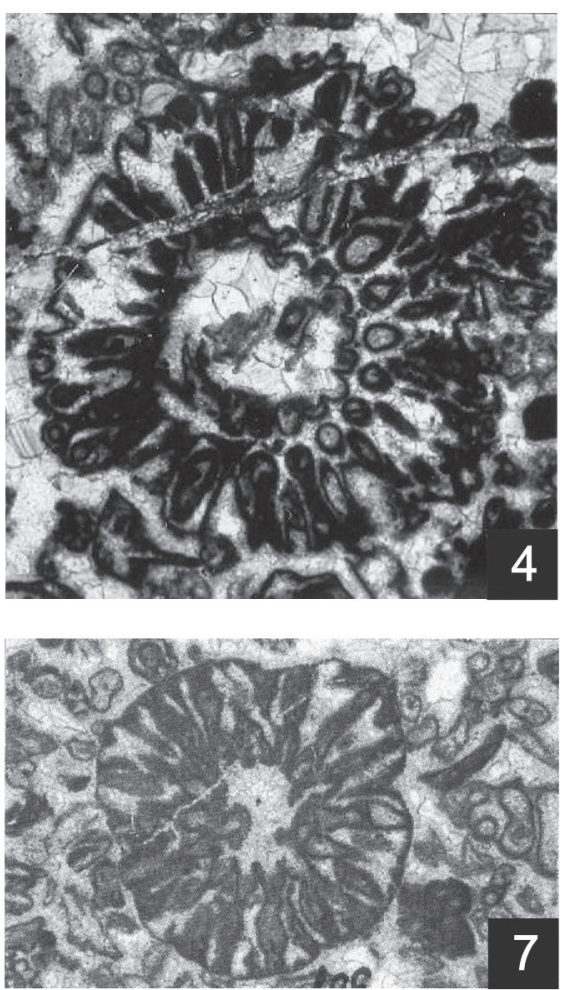
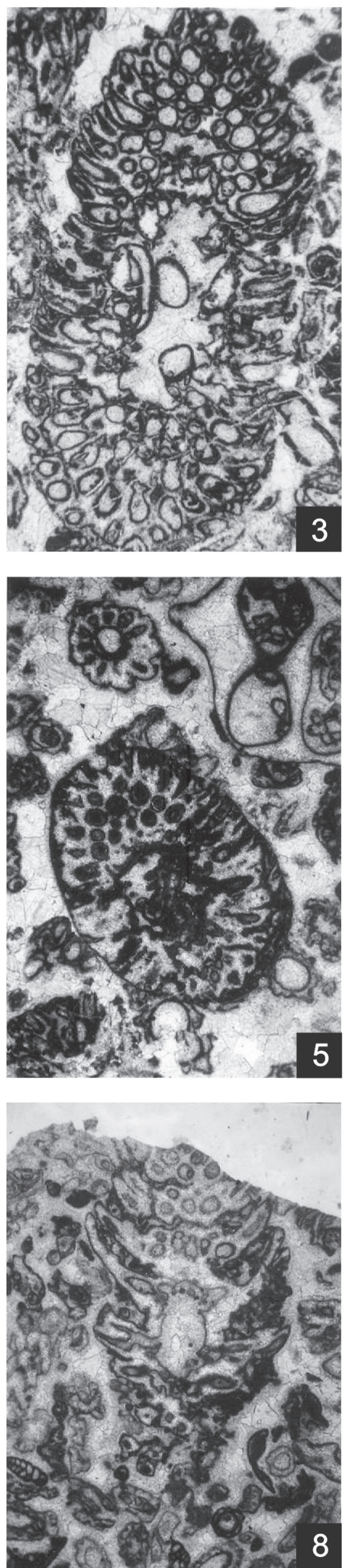


\section{Plate VII}

1-7 Selliporella donzellii SARTONI \& CRESCENTI var. donzellii

1-2 Tangential-oblique sections. In the lower part of the pictures, part of the preserved articulation, reduced annulation and outer fissuring of the skeleton resulting from the individualization of the primary and secondary laterals can be observed. In the lower part of the pictures, the enlargement of the primary and secondary laterals is visible. Slides: fig. 1, 0-79/201, x22; fig. 2, 0-79/30, x17.

3 Longitudinal-tangential section. Enlargement of laterals with emphasized intercommunication of the primary laterals of adjacent whorls. Slide: 0-79/192, x22.

$4 \quad$ Transverse section. In the central cavity of S. donzellii is transverse section of Salpingoporella croatica SOKAČ. Slide: 0-79/210, x17.

$5 \quad$ Longitudinal section. A complete central cavity with well-preserved squatty primary laterals. Slide: 0-79/94, x22.

6 Tangential section. In the lower part of the thallus, articulation is still apparent, passing to the upper part to reduced annulation indicated by horizontal fissures between adjacent whorls. Slide: 0-79/115.

7 Tangential section. A well-accentuated annulation between the articles of neighbouring whorls. Slide: Fig. 7, 0-79/121, x12,5. 


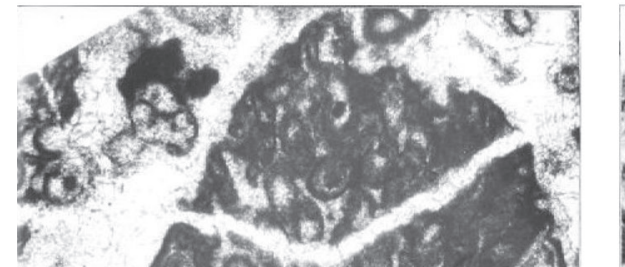

opin- 2

$104585 y$

$-10.0 \%$

2000

son. 0.1

neren

$\left.80^{2} x^{-2}\right)^{2}-1$

$-5=5 x+2$

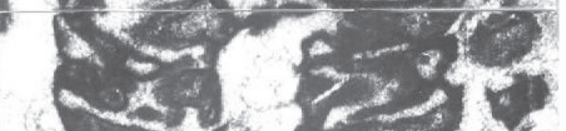

$-1,+\infty$

$\frac{\cos ^{2}-\frac{\pi}{4}+2}{42}$

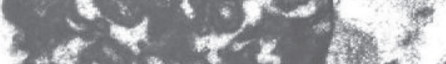

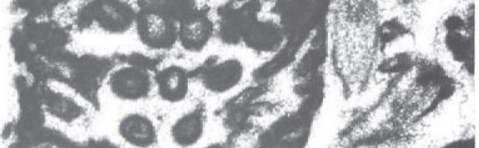

$20 \cos ^{2}$

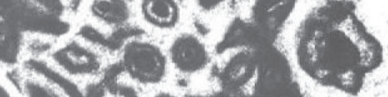
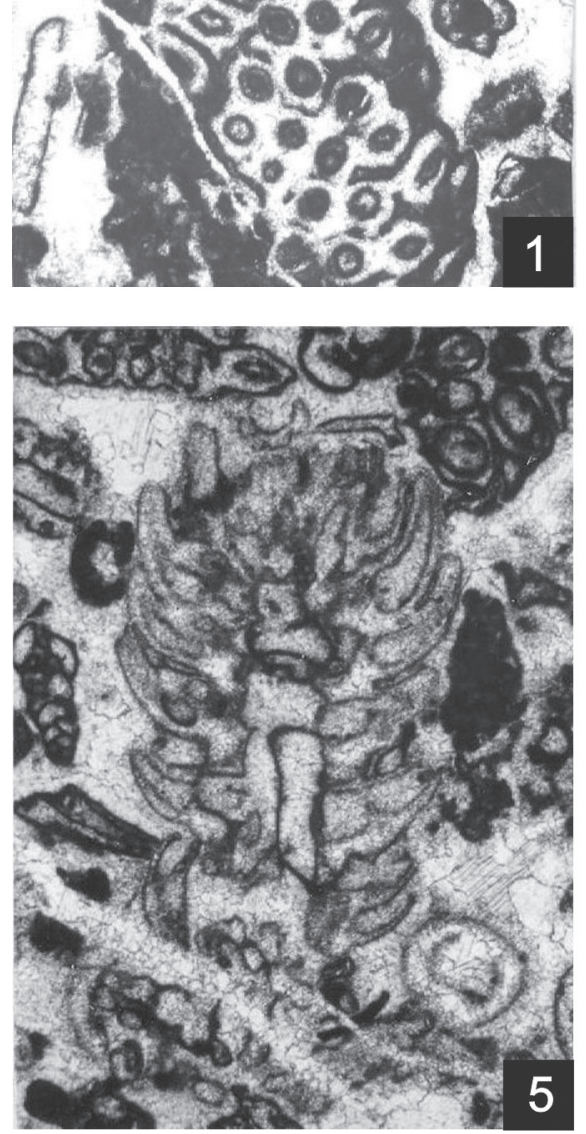

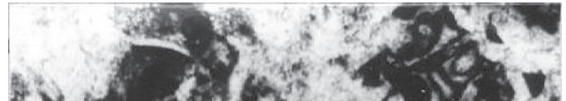

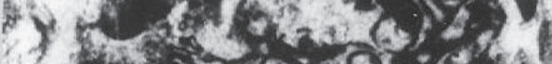

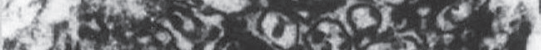
ix on 020 in 2003

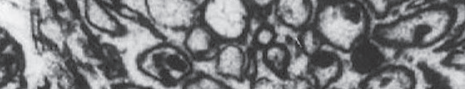

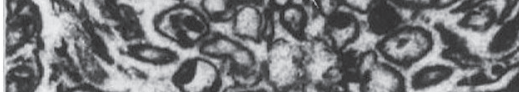

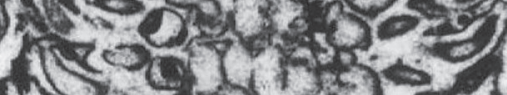

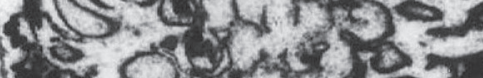

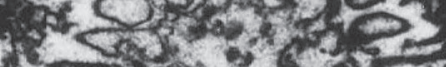
$1+-8$. $4(2)^{2}=$

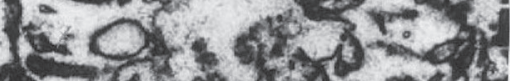
$x-20-10-y^{2}$

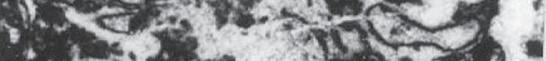

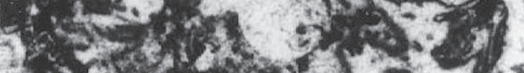
act 2 on 20

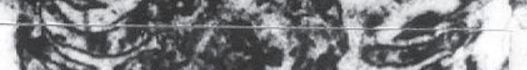

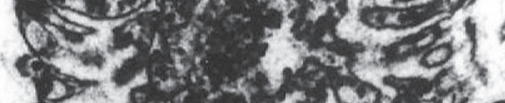

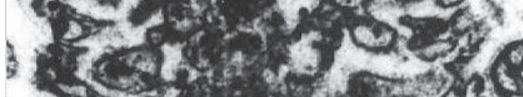
$702,\left(\frac{5}{5}\right)^{2}$

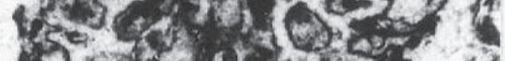
costions Herofore

- ine di

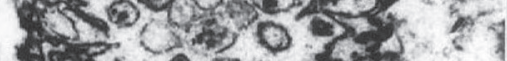

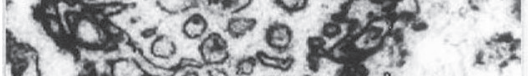
1 k0 0000.

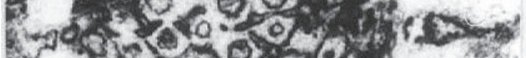
1) की

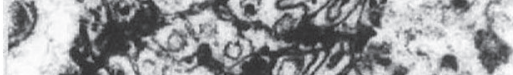

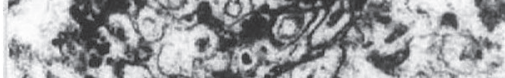

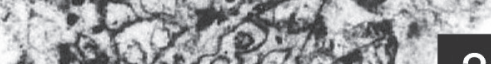

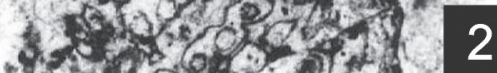

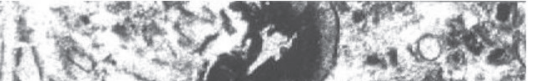
th $=2,2,20$ - $x_{0} \sigma^{2} 010$ 4 $-100000$ 1. 100025 . (e) 000 $-1000003$ \% 1500\% - 2 oloo - to 8 roto

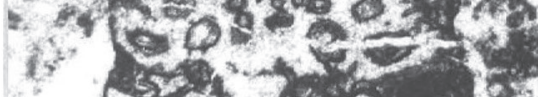
(5) $3 x^{2}+x^{2}-10$

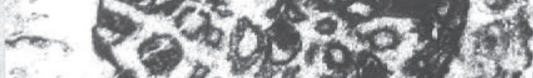

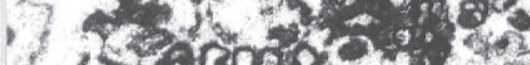

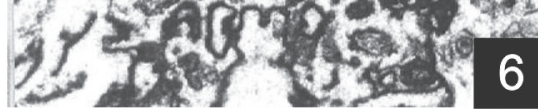

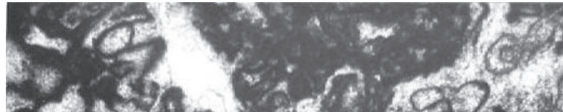

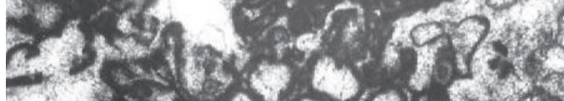

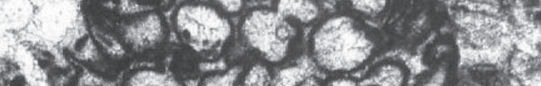
3) (a) 4 - ato.6. 2.t.

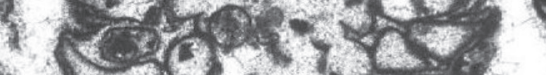

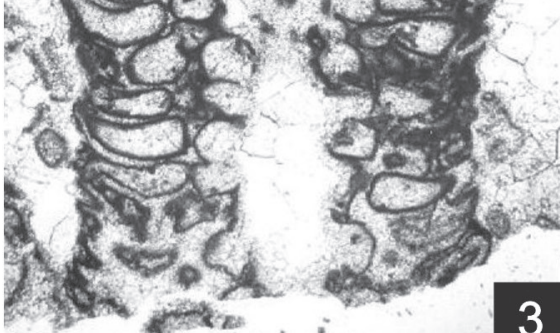

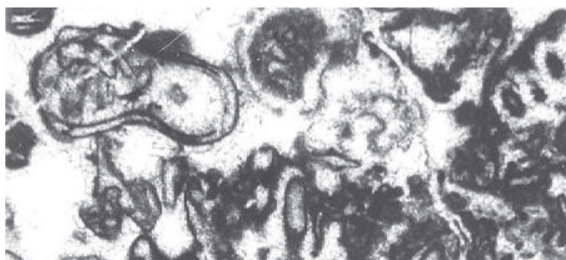

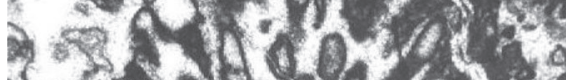
Sors?

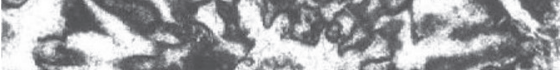

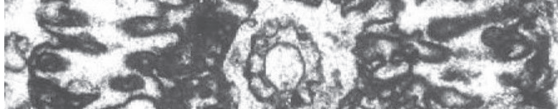

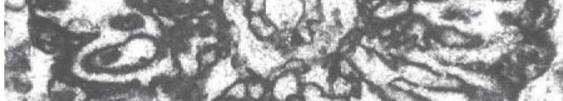

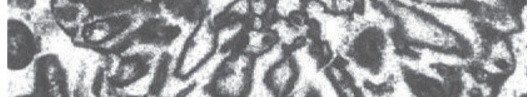

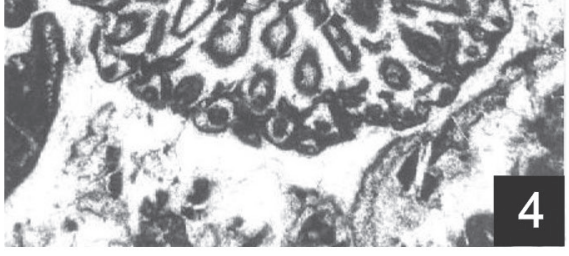

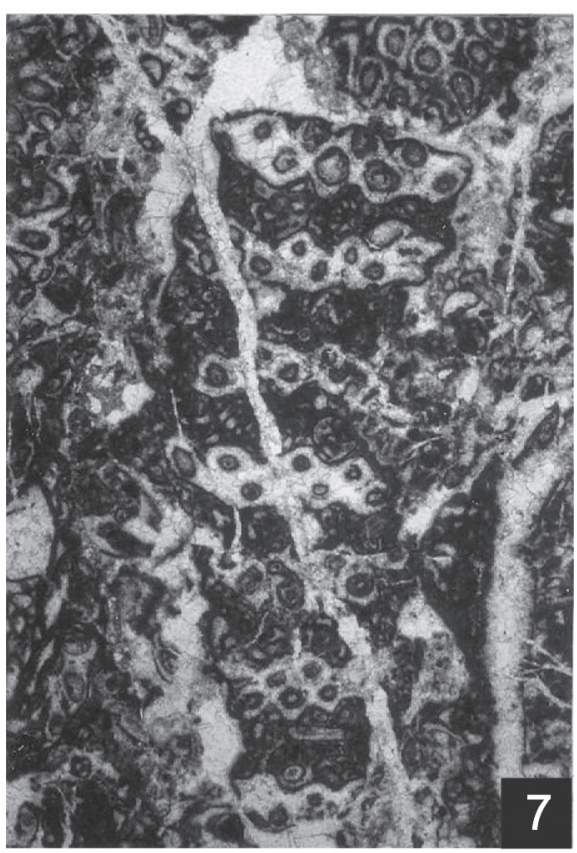


Plate VIII

1-9 Selliporella donzellii SARTONI \& CRESCENTI var. donzellii

1 Oblique section. An example of the articulation of part of the skeleton. Slide: 0-79/174, x22.

2-3 Oblique sections of a clearly marked central cavity with well-preserved primary laterals. Slides: 2,0-79/188, x14; fig. 3, 0-79/195, x17.

4 Oblique-transverse and transverse section. Slide: 0-79/63, x17

5 Oblique sections. A fragment of Salpingoporella croatica SOKAČ on the right. Slide: 0-79/182, x14.

6 Different sections of both varieties of the species Selliporella donzellii. Slide: 0-79/175, x12,5.

7 Transverse, slightly oblique section with a clearly marked central cavity. Slide: 0-79/192, x17.

8 Tangential section. The articulated part of the skeleton passes into the part of the induced annulation. Slide: $0-79 / 209, \times 12,5$.

9 Tangential section with fissured outer surface and the separation of envelopes of pairs of secondary laterals. Slide: $0-79 / 134, \times 12,5$. 

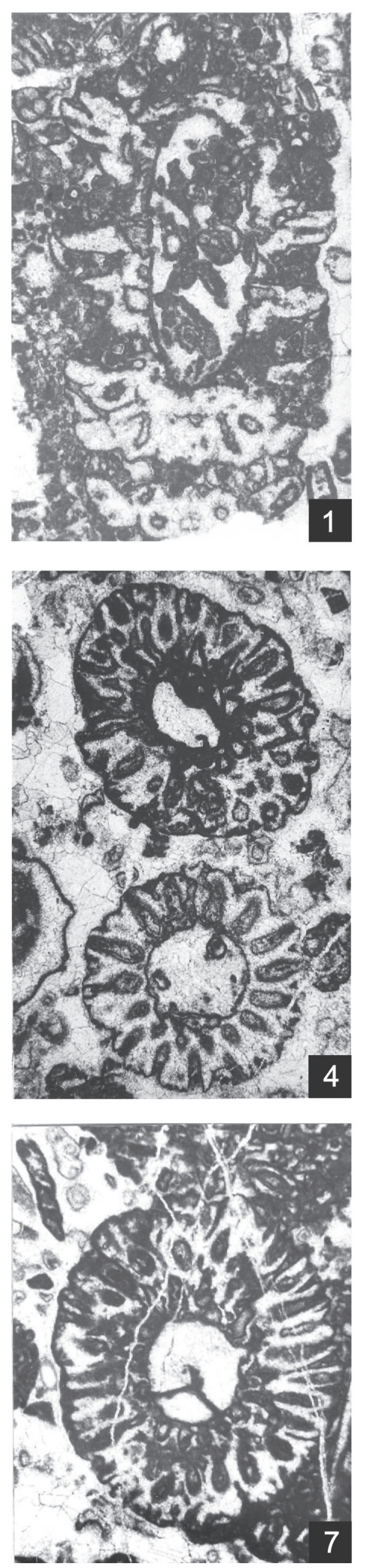

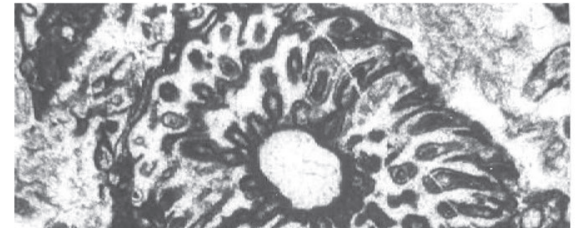

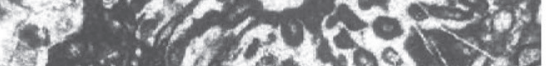

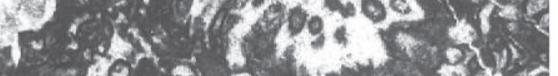
tar ar. - S. 4 A $210 \%$ $\because-1.210$ (3) $-1+20$. 4. 1.2 है

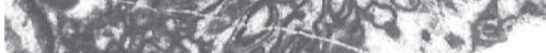
$x^{2}+202-101$. $30235-4=4$

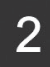

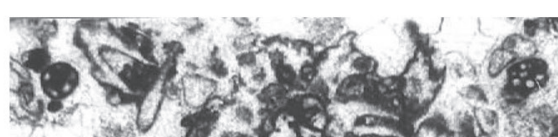

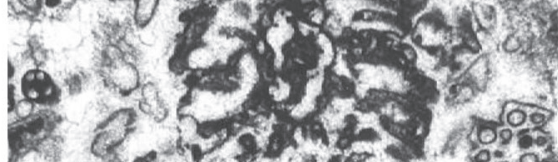
$P$ Qny 100 3,

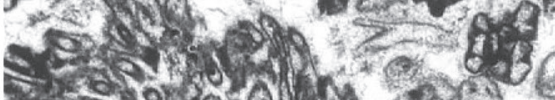

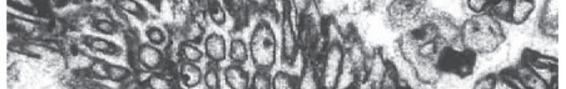

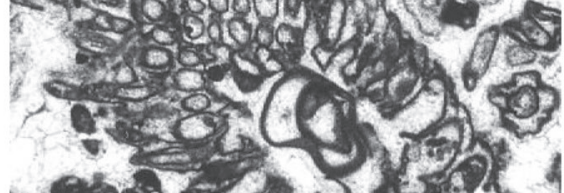

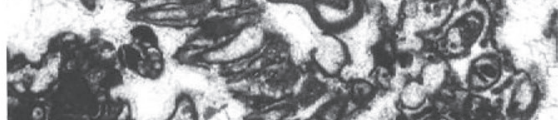
o.j.

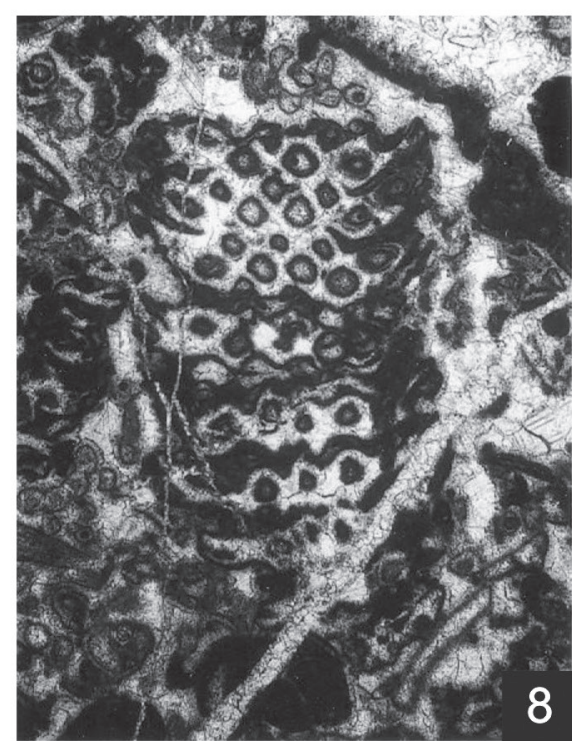

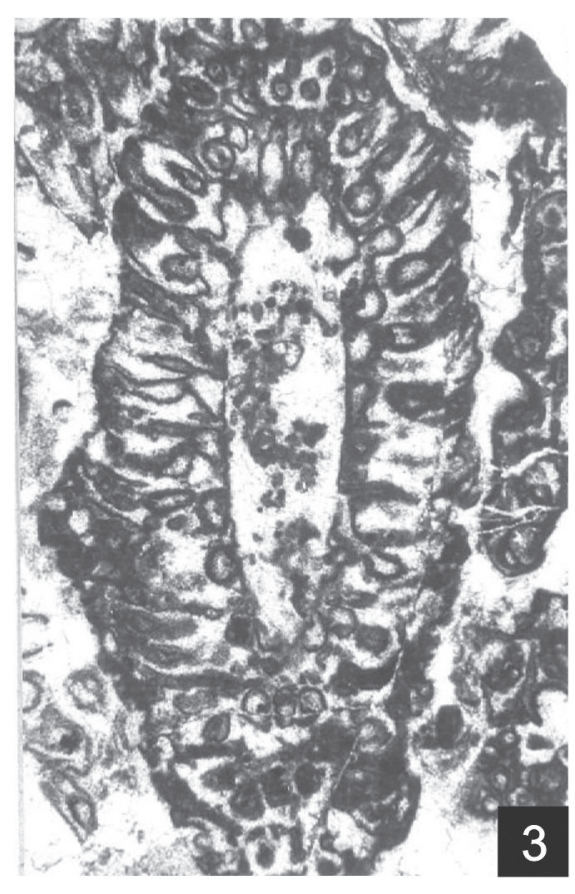
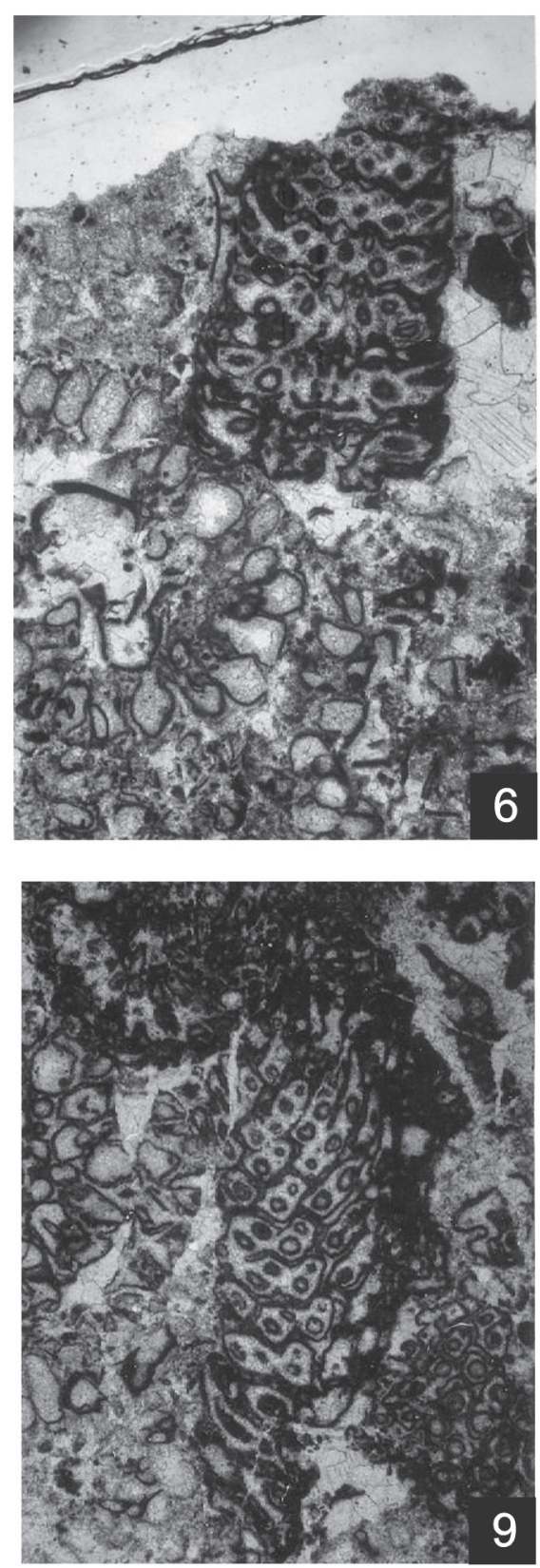
Plate IX

1-4 Selliporella donzellii SARTONI \& CRESCENTI var. donzelli

1 Longitudinal section. Slide: 0-79/113, x14

2 Tangential section. Slide: 0-79/183, x14

3 Oblique section. Slide: 0-79/99, x14

4 Oblique section. Slide: $0-79 / 42, \times 12,5$ 

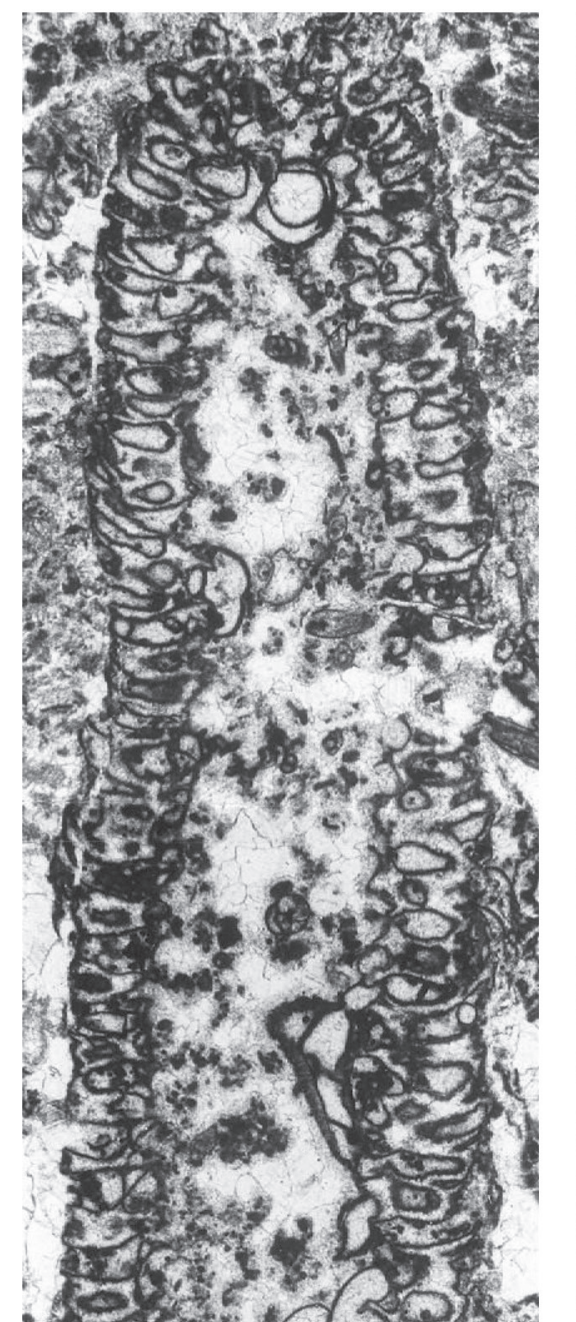

- 20 rat sola

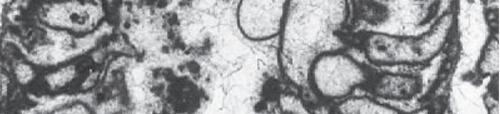

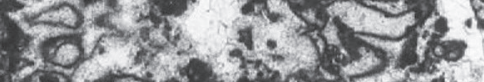
and It a 15. ${ }^{2}$ का

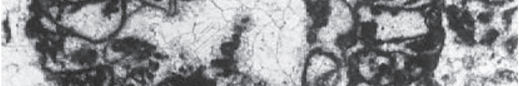
Cis fo trit

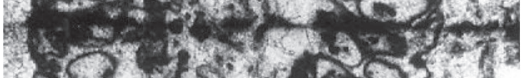

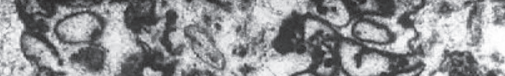

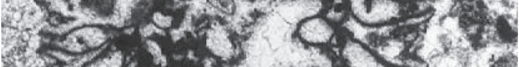
ISA $-1,-3)^{2}$ -2.8. - $\cos ^{2}$ or

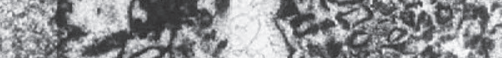
108.

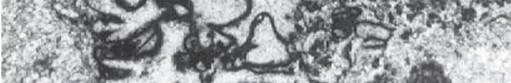

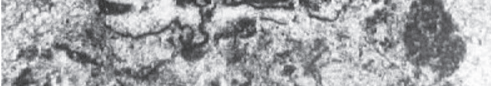

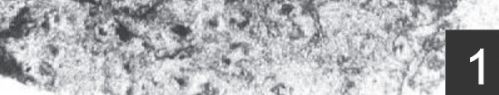

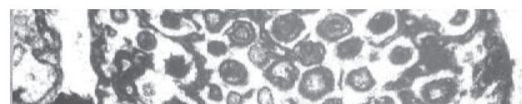

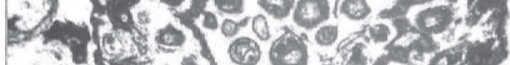

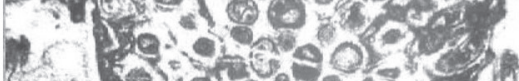
- Nora som n

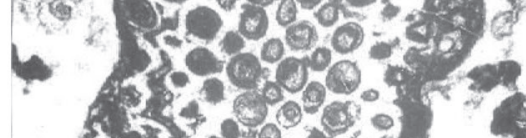
(1) $000201 i^{\circ}$ \& $\rightarrow 0105$ स cosin 3. $100 \%$. - Topo ijo

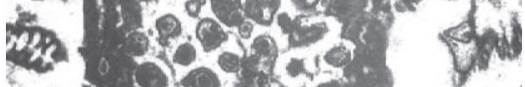

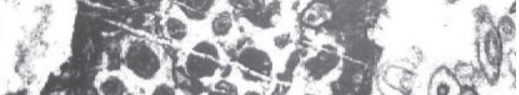

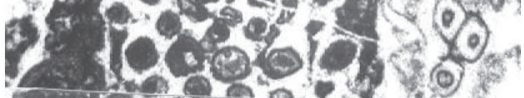
iposis bo (7) 70000110 .

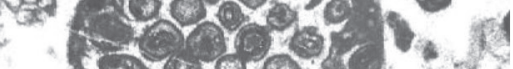
(a) 00 $3+20030$. $650-20 y-2$ 1300001.

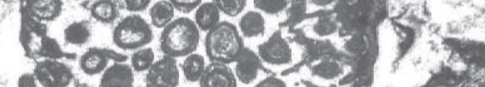

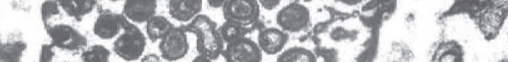

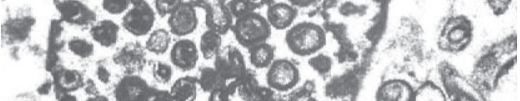

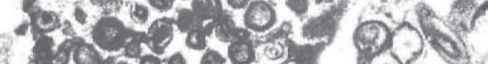
beto. verese bis $1 x^{2}+2 x^{2}-62$ S(i)

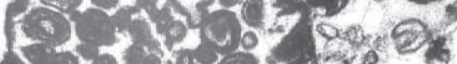
$x+4010$ a $3+x+3 x^{2}$

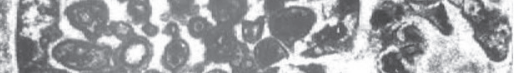

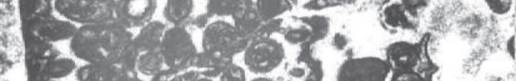
15 - 50 . $4-20000$ 20140.54 $36205 \%$

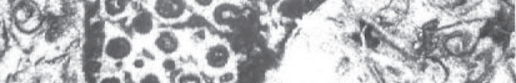
1 bjox

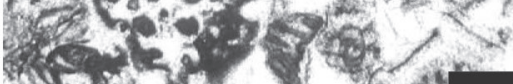
${ }^{2}{ }^{2}, \mathrm{Fd} 2$
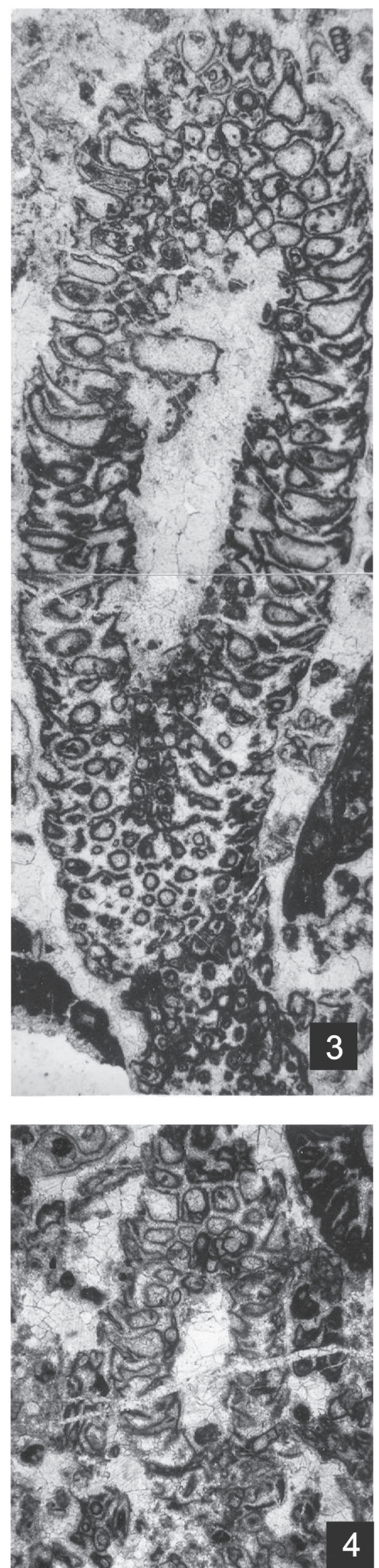


\section{Plate $X$}

1-9 Selliporella donzellii SARTONI \& CRESCENTI var. gallaeformis (RADOIČIĆ) n. comb., n. var.

1-2 Oblique sections - demonstrating extremely large secondary laterals, in fig. 2 of a pronounced piriferous shape. Slides: fig. 1,0-79/173; fig. 2, 0-79/125, x17.

3 Oblique-tangential section. Extremely large secondary laterals. Slide: 0-79/163, x17.

4-6 Oblique sections - demonstrate very large irregular secondary laterals, in fig. 6 partially clearly piriform. Slides: fig. 4, 0-79/182, x17; fig. 5, 0-79/197, x22; fig. 6, 0-79/177, x14.

7-8 Oblique sections. In the pores of very large secondary laterals, the weakly visible accumulation of cysts can be observed. Slides: fig. 7, 0-79/183; fig. 8, $0-79 / 123, x 17$. 


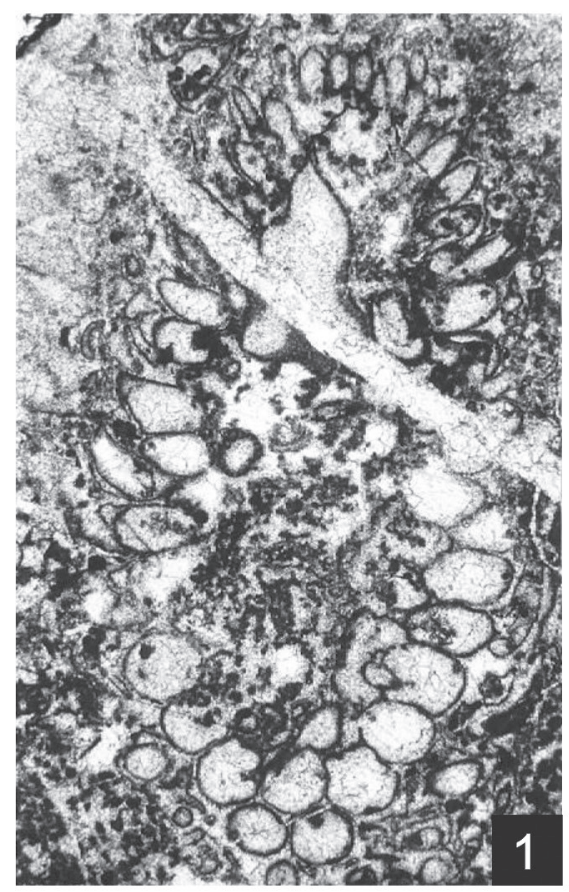

- $547 x$ 6. 4.

$100 \% 3$

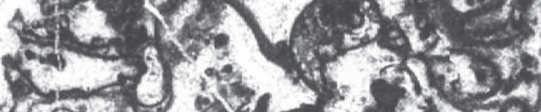

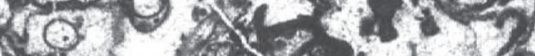
C. $+2,1,20$

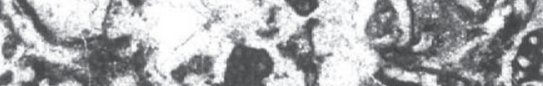
oversur Le 40 (1) 1000 15.2

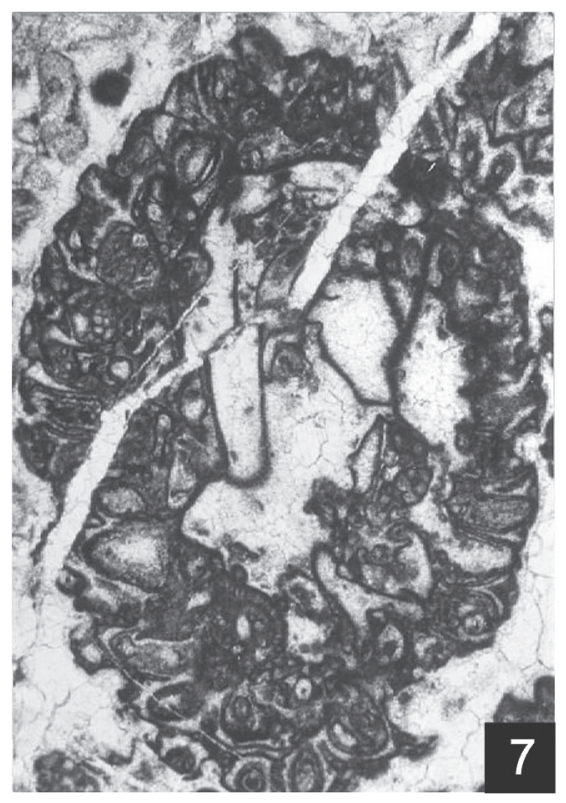

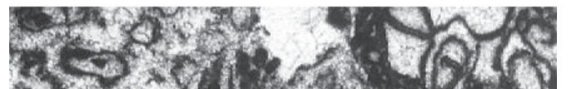

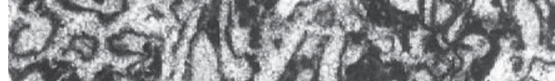
2. (1)

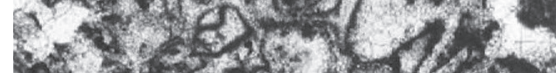

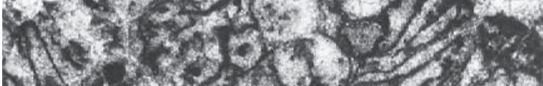

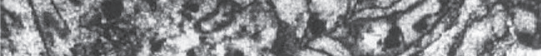

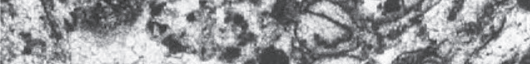

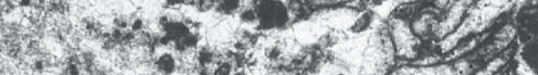

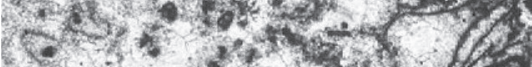

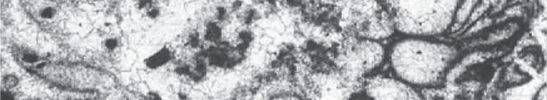

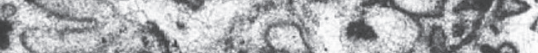

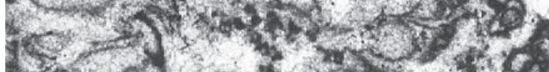

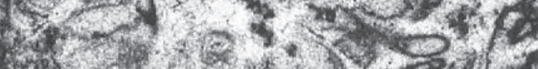

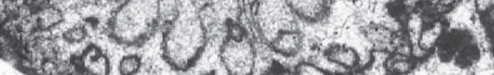

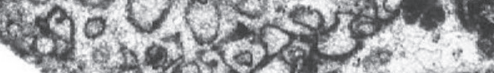

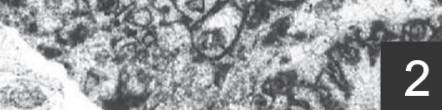

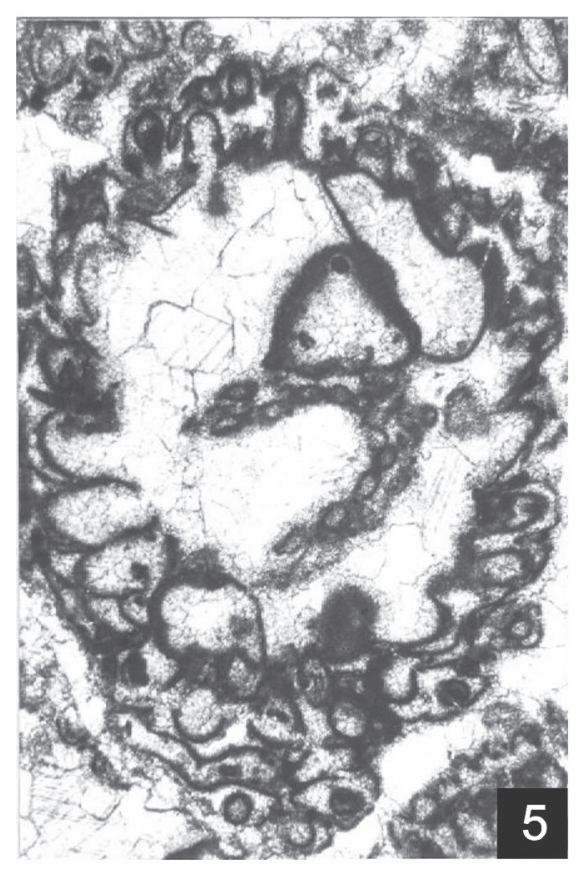

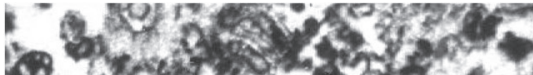

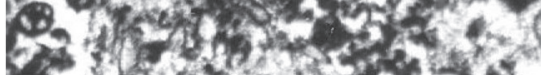

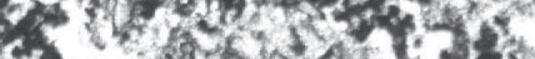

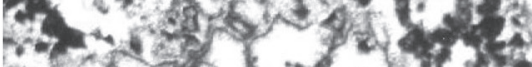

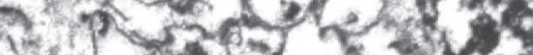

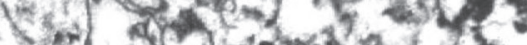

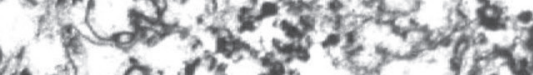

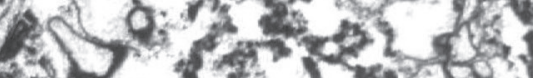
$7 \times 2-77^{2}+x^{2}$

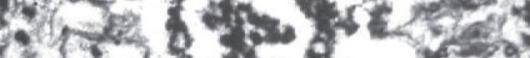

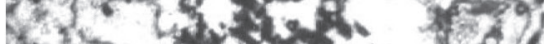

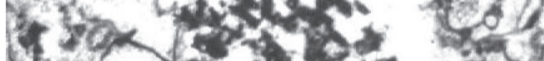

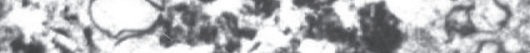
che 4 -

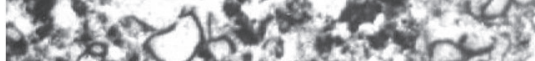

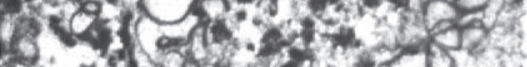

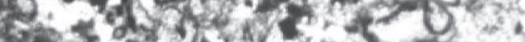

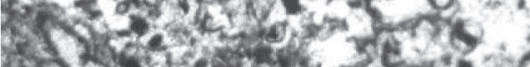

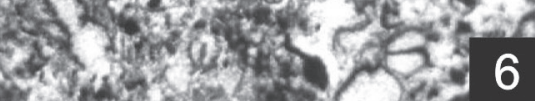
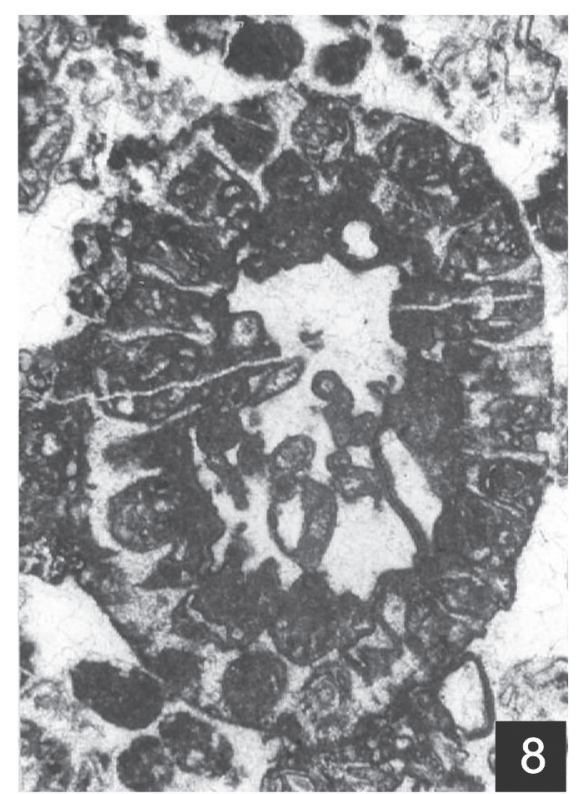

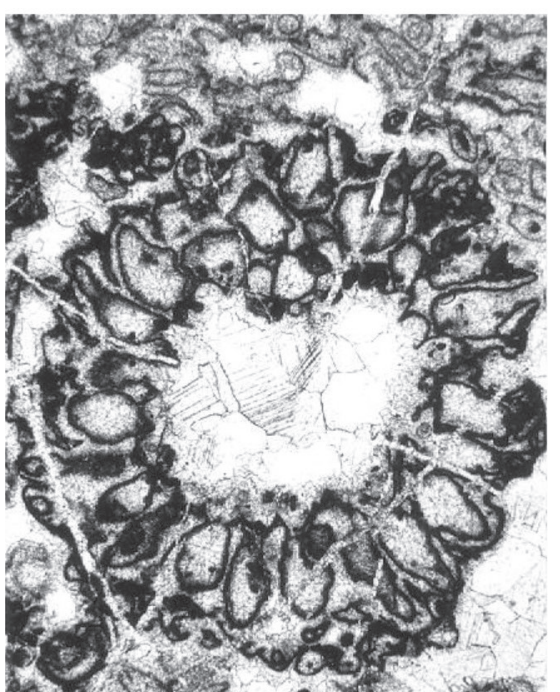

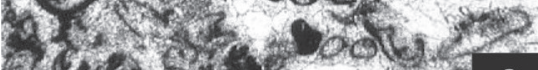

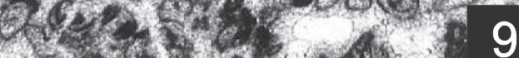




\section{Plate XI}

1-9 Selliporella donzellii SARTONI \& CRESCENTI var. gallaeformis (RADOIČIĆ) n. comb., n. var.

1,3 Oblique sections demonstrate large, partly very irregular, secondary laterals. The secondary expanded central cavity is the result of the destruction of the primary laterals. Slides: fig. 1, 0-79/162, x14; fig. 3, 0-79/122, x17.

2 Longitudinal-tangential section. Slide: 0-79/170, x14.

4-6 Tangential sections demonstrate various types of pores of secondary laterals, round, polygonal, irregular in fig. 6 and deformed as a result of reciprocal pressing of adjacent laterals. In the pores of the cross section in fig. 5 , individual cysts can be observed. Slides: fig. 4, 0-79/56, fig. 5, 0-79/144; fig. 6, 0-79/164, $\mathrm{x} 22$.

7-9 Oblique sections. In the sections of Fig. 7 and 9, the large primary laterals have been partly preserved with noticeable intercommunication. Slides: fig. 7, 0-79/156; fig. 8, 0-79/120, fig. 9, 0-79/156, x17. 

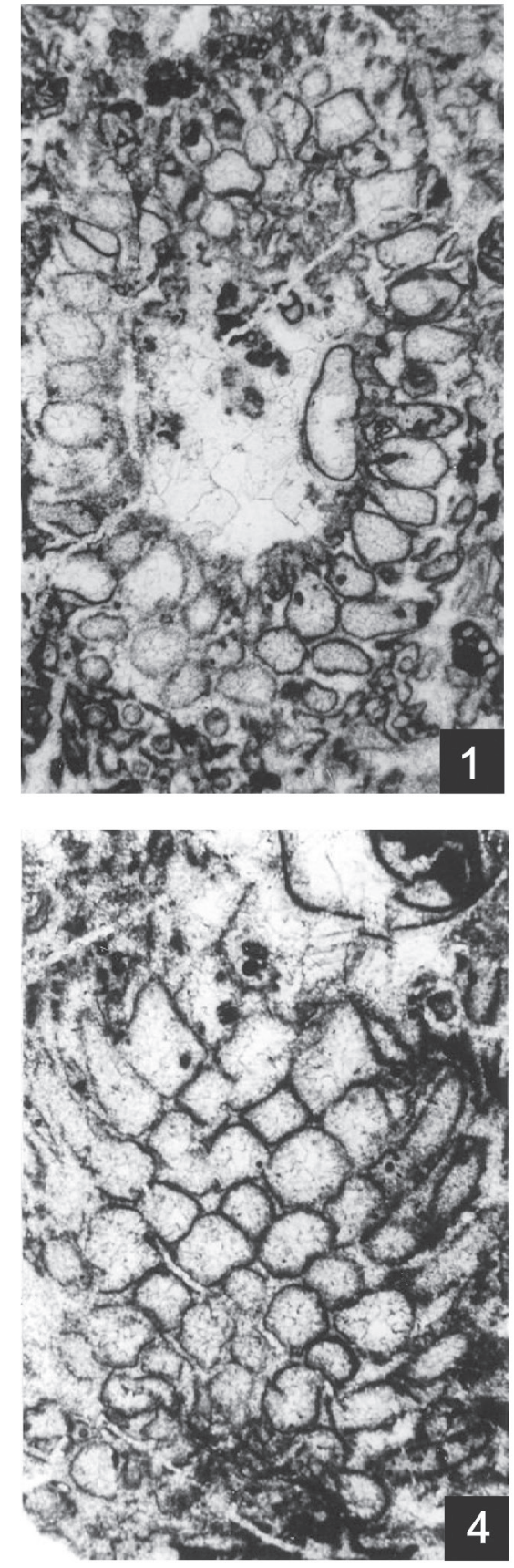

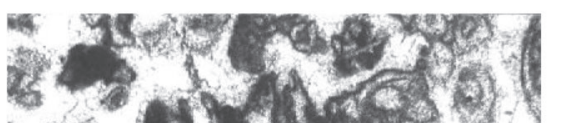
W 15 or 326 xis to - 42,2 I 0.5 L ( $) 1$, 00 s. 5. 10.5 627
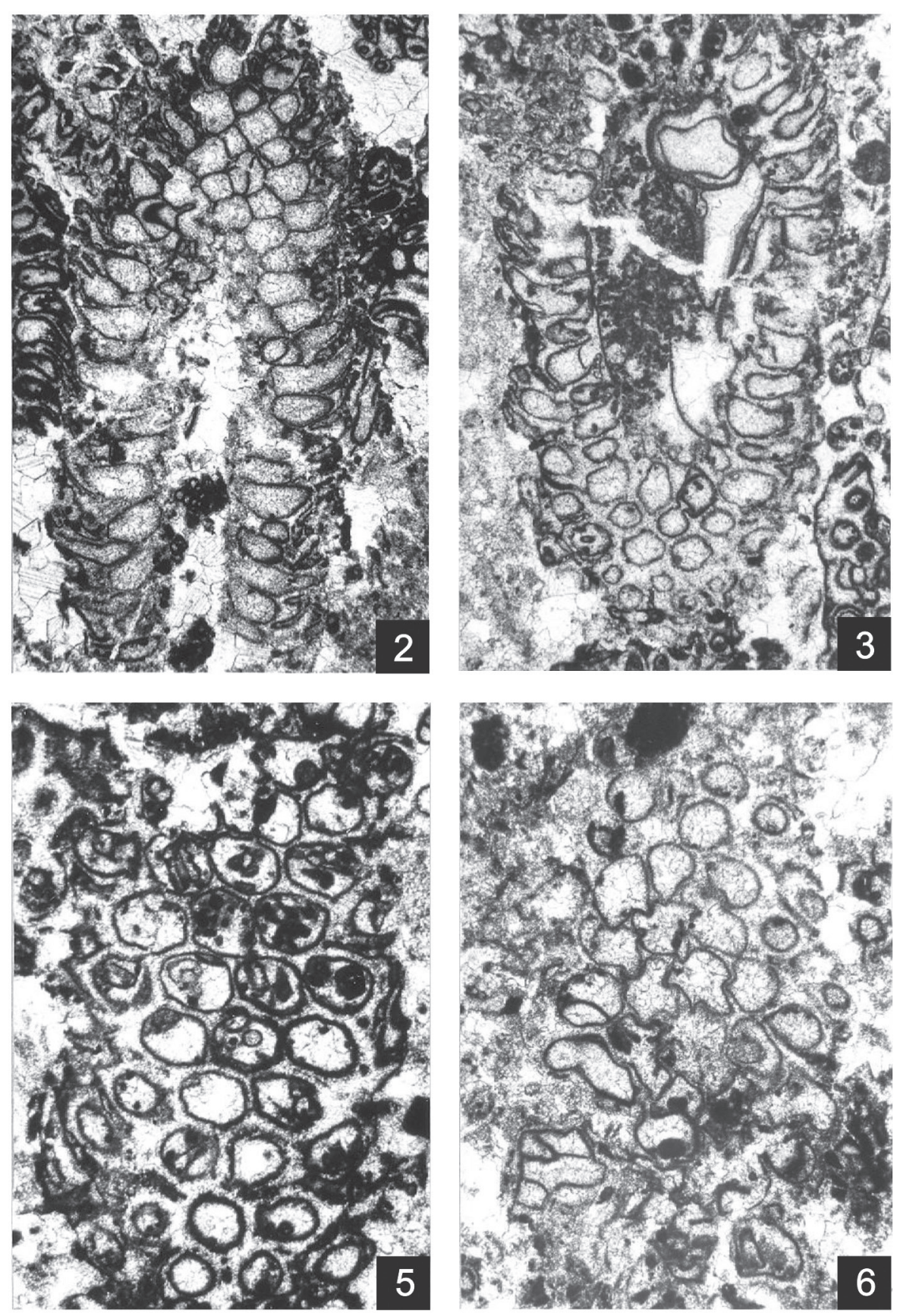

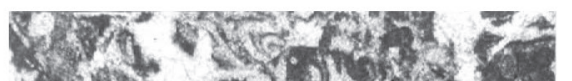

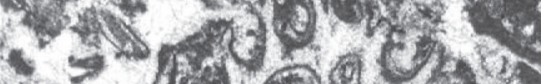

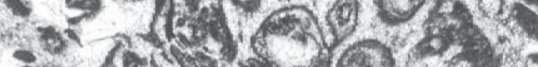
6 a d 30 35 5

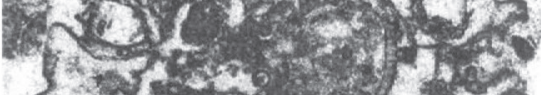
Sent 1425 ros 20

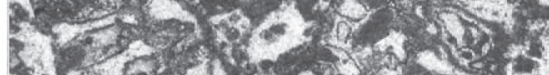

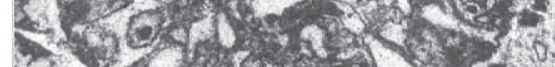

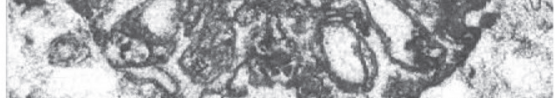
18. 6 - $-2-8$

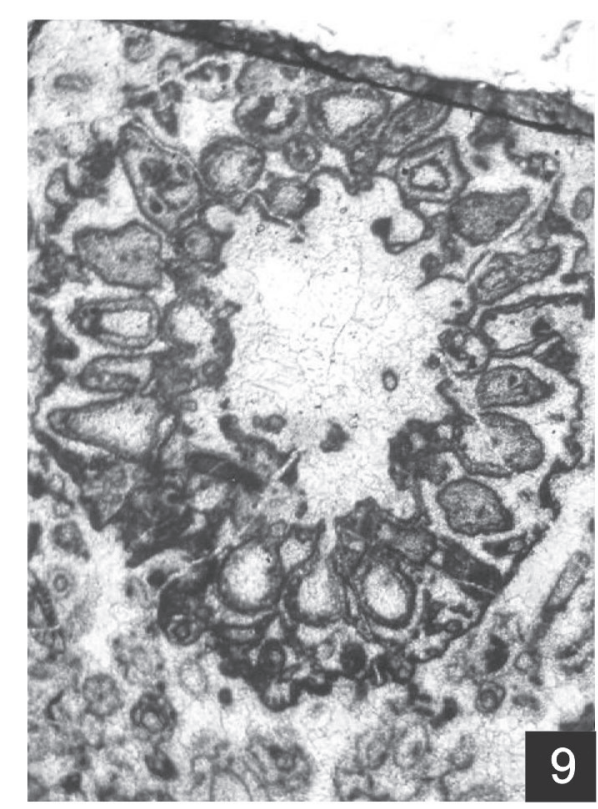




\section{Plate XII}

1-10 Selliporella donzellii SARTONI \& CRESCENTI var. gallaeformis (RADOIČIĆ) n. comb., n. var.

1 Longitudinal section. Secondary laterals of bagged piriform shape. Slide: PPB-125, x12,5.

2 Tangential section. Visible deformed pores of secondary laterals. Slide: 0-79/147, x17.

3,7 Oblique sections. In fig. 7 partly preserved primary laterals of visible intercommunication Slides: fig. 3, 0-79/100, fig. 7, 0-79/120, x17.

4-5,8 Approximate cross-sections. Sections show different shaped secondary laterals. In fig. 5, the large primary laterals of visible intercommunication are preserved. Fig. 9 demonstrates the section of the preserved outer part of the skeleton - the primary and proximal parts of the secondary laterals are destroyed. Slides: fig. 4, 0-79/169, x22; fig. 5, 0-79/186, x17; fig. 8, 0-79/36, x14.

6 Cross-oblique section with only the preserved distal part of the calcareous envelope. Slide: 0-79/56, x17.

9-10 Details of sections. Arrow - a cluster of cysts in common envelopes. Slides: fig. 9, 0-79/180; fig. 10, 0-79/183, x40. 

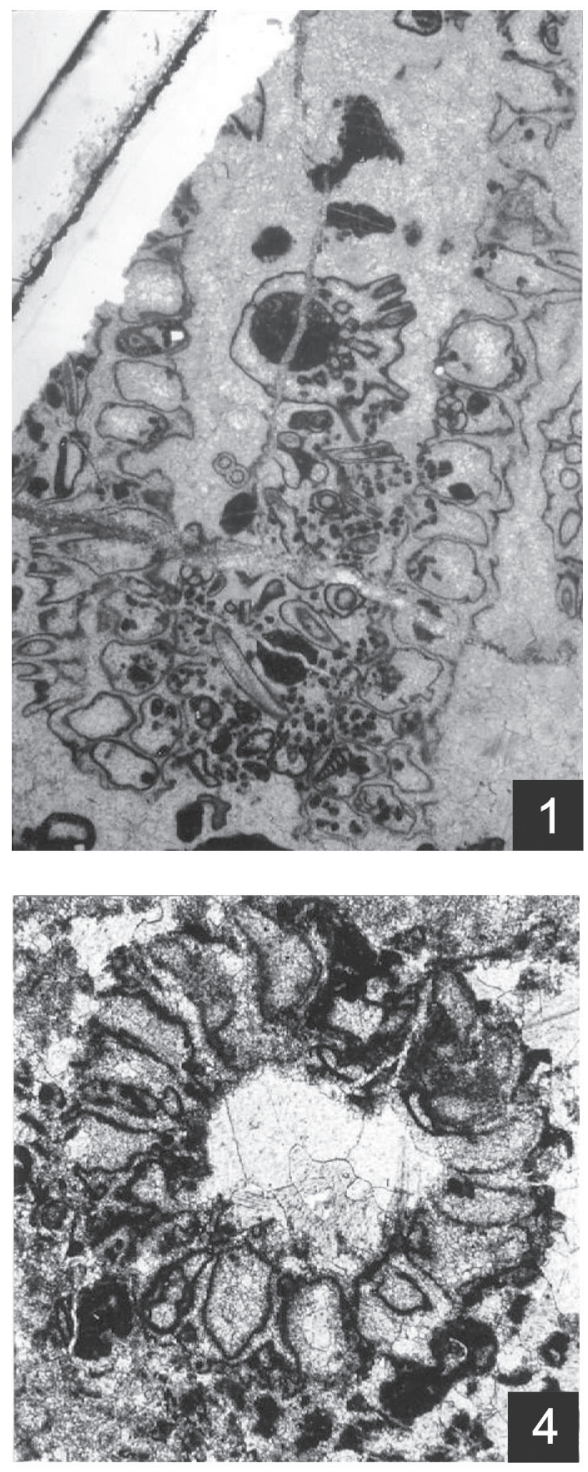

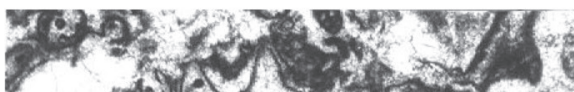
- do Jujum 45 ank (3\%)

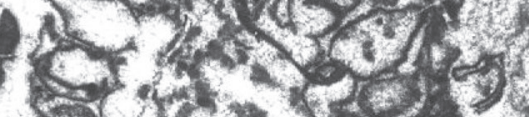
acorer al

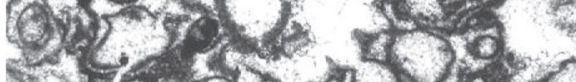

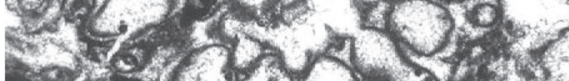

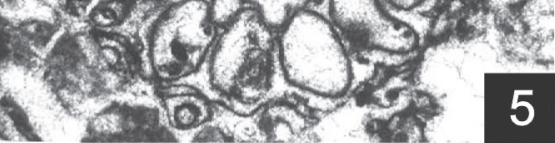

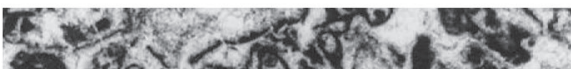

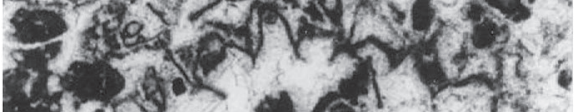

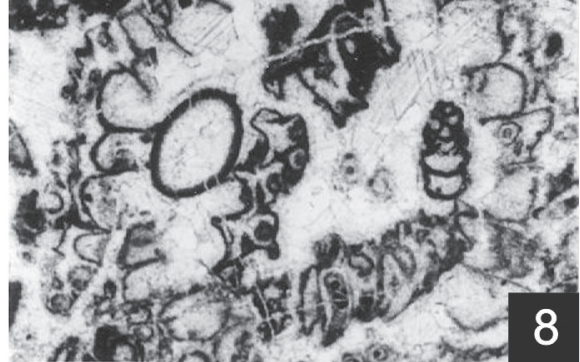
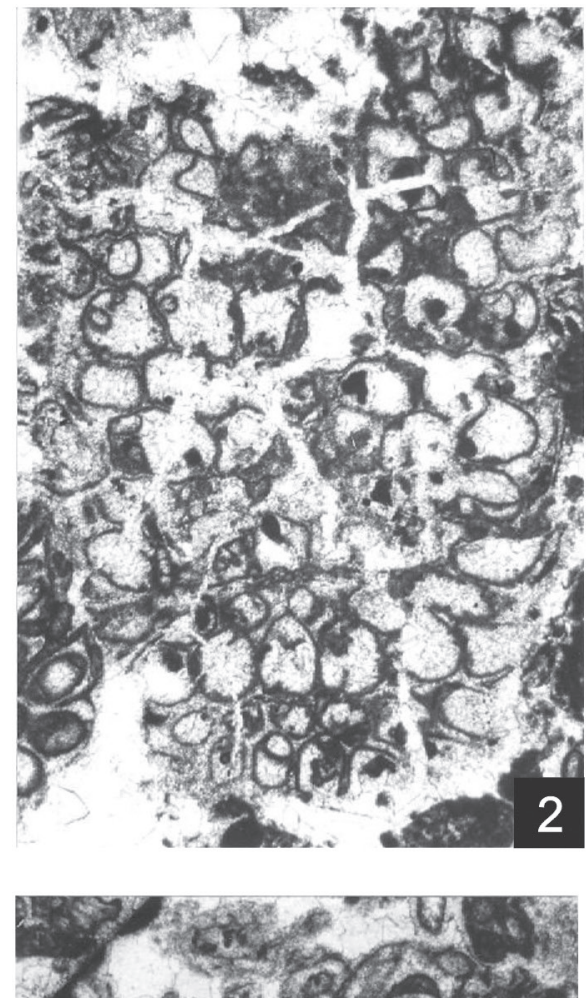

Ii englatom

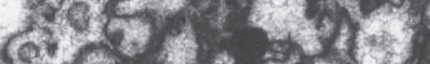

\%) 1035

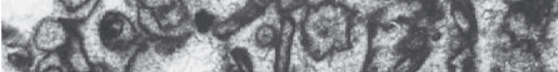

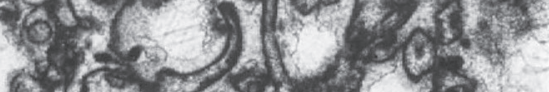
gicen

$2<0.5 \times+2=$

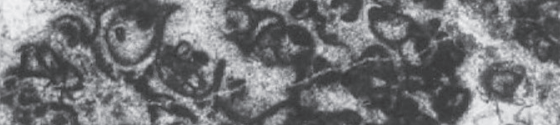

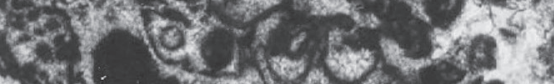
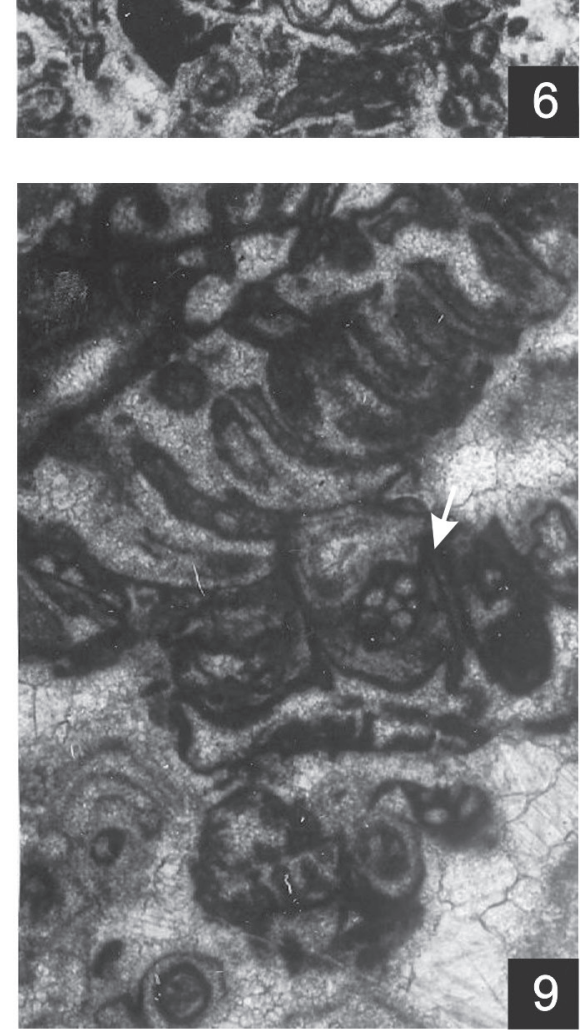

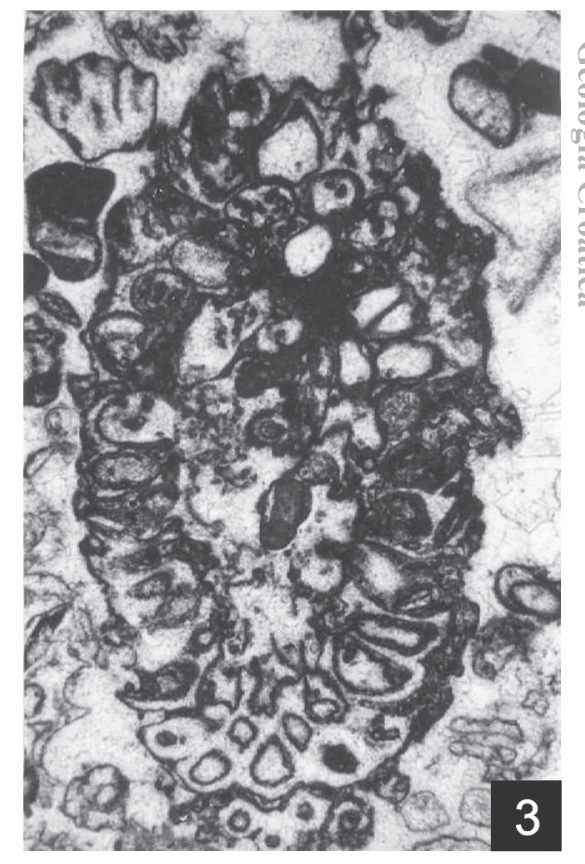

Whoymonis 0 - errusulo. 1. 10002

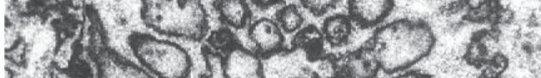
$4754+20$ $1+$ iss $20 \%$ $1028+3=1$

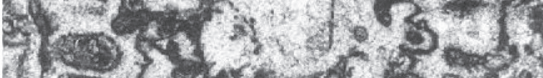

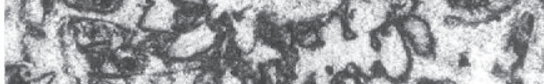

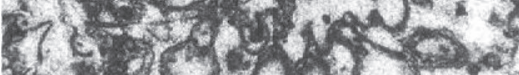
1. 00027 o 1. 3 ros?

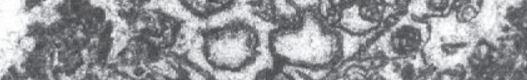

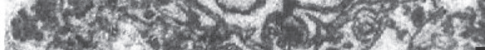

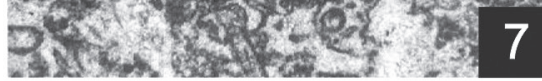

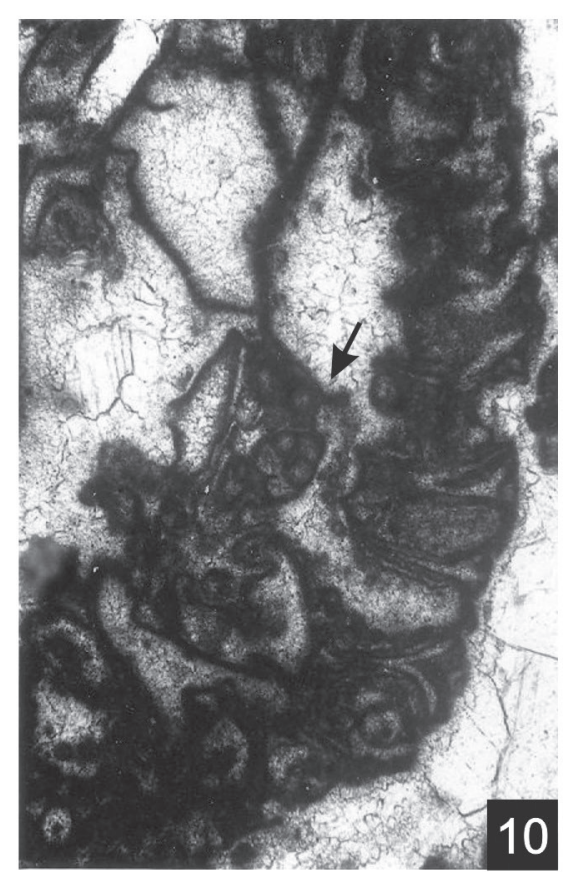


Plate XIII

1-9 Selliporella cornutuformis $\mathrm{n}$. $\mathrm{sp}$.

1 Longitudinal-tangential section. Slightly claviform thallus with noticeable widening and destruction of the central cavity. Undivided pirifer laterals in the basal part with short segments which are developed upwards into dividing laterals, with an increase in the number of dense and differently directed secondary laterals with a significant increase in the height of the segments. Slide: PPB-125, x12,5.

2 Longitudinal section. Slide: KOB-372/10, x12,5.

3 Oblique-tangential section. In the higher part of the cross-section, the number of pores in each segment suggests 3-4 secondary laterals. Slide: SB-8B/20, $\mathrm{x} 12,5$.

4-9 Oblique sections. Slides: fig. 4, SB-8B(9, fig. 5; SB-8B/8; fig. 6, SB-8C; fig. 7, KO13-372/3; fig. 8, SB-8B/18; fig. 9, SB-8B/17. Figs. 4-6 demonstrating different directional growth of a larger number of secondary laterals (3-4), $\times 12,5$ 


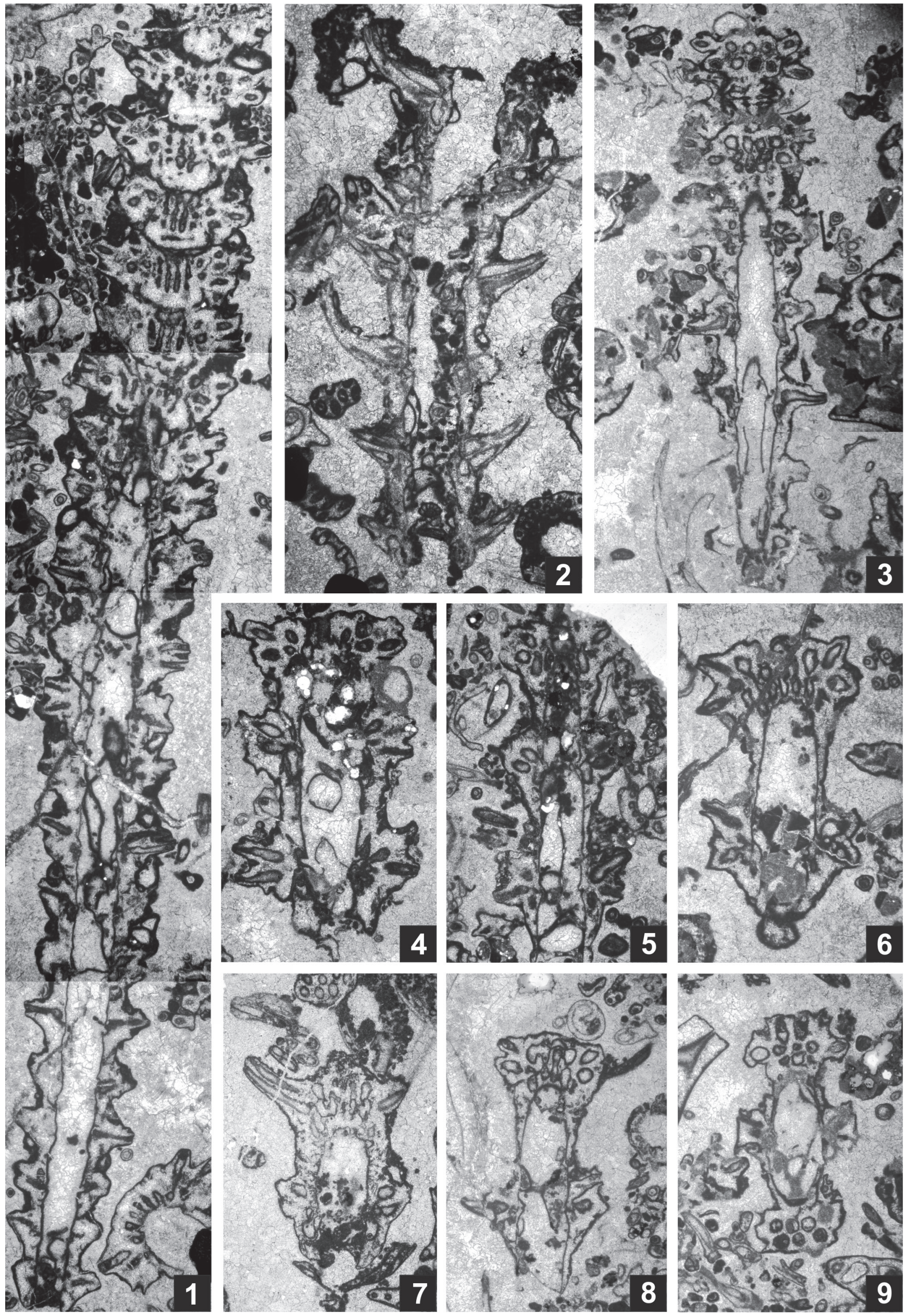




\section{Plate XIV}

1-9 Selliporella cornutuformis n. sp.

1 Tangenial-longitudinal section. The number of pores in individual segments suggests a greater number of secondary laterals as a consequence of the higher segments. Slide: KOB.372/3.

2 Longitudinal, slightly oblique section (holotype). It demonstrates the slight widening and narrowing of the central cavity and the greater distance of adjacent whorls. The entrance pore of the primary lateral is at the level of the central cavity narrowing. In the upper part of the section are 3-4 secondary laterals. Slide: SB-8B/12.

3,6-7,9 Transverse sections. The sections are at different segments levels, each at approximately the level of the entrance pores of the primary laterals. The sections demonstrate distal individualization of secondary laterals and their spiny shape. Slides: fig. 3, SB-813/12; fig. 6, SB-8B/14; fig. 7, SB-813/15; fig. 9, SB-8B/9.

4 Oblique section. Slide: SB-8B/20

5 Longitudinal section. At the level of narrowing, the small entrance pore of the primary lateral Slide: SB-8B/4.

8 Tangential section of a segment. Grouped pores suggest up to 5 secondary laterals. Slide: KOB-372/14. 


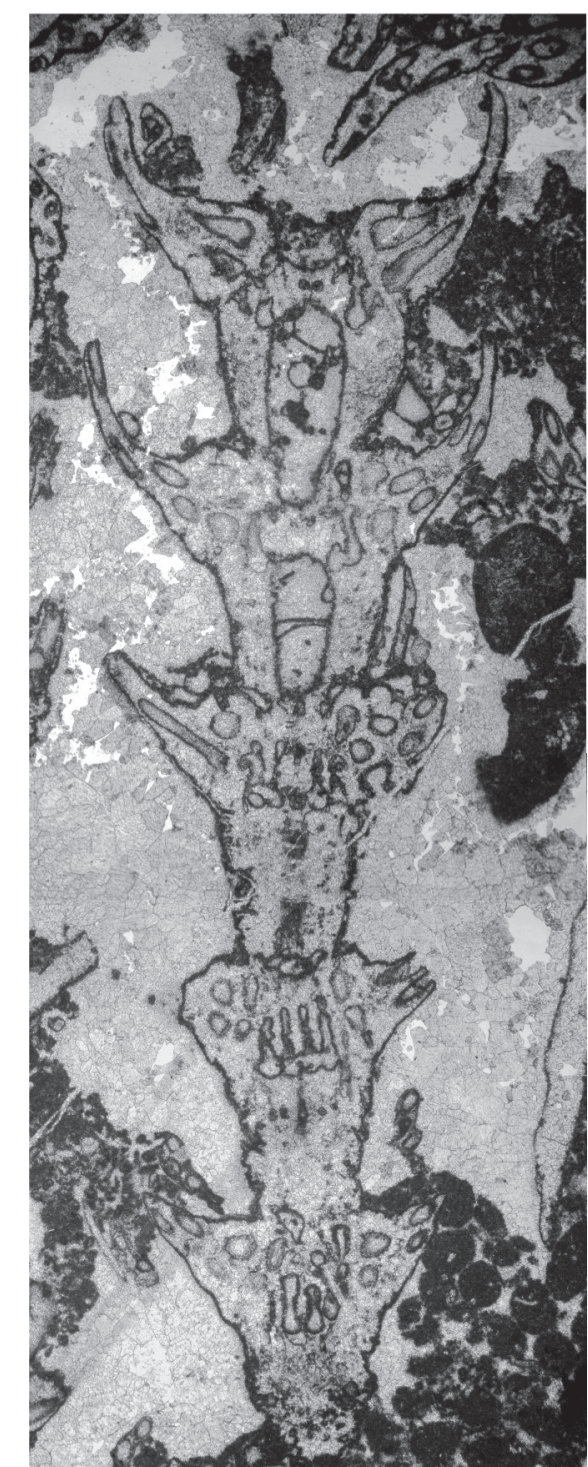

6. $60.000 \%$.
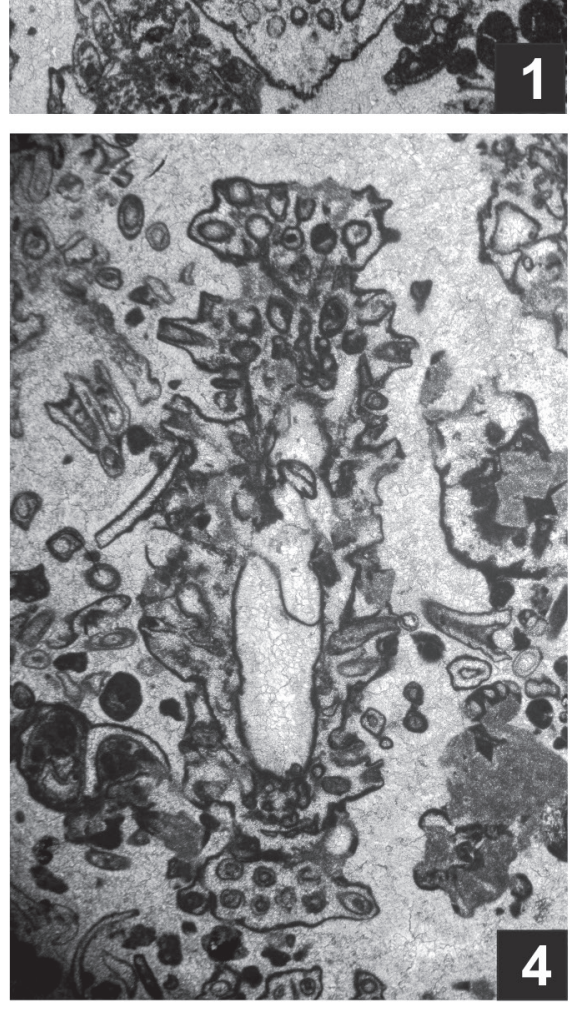

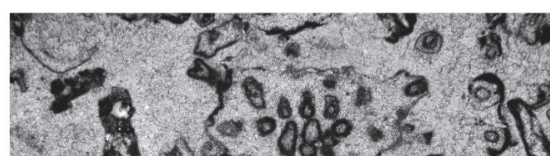

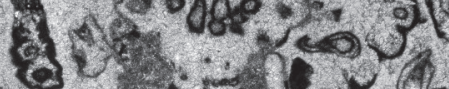
s.

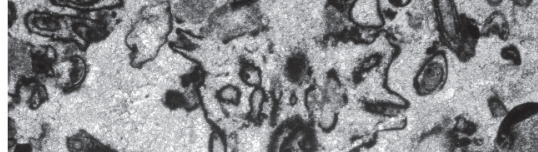

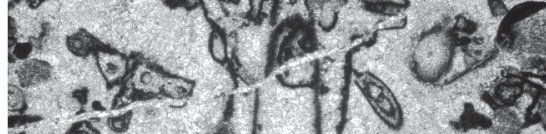

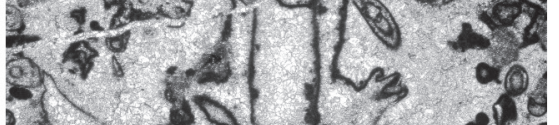

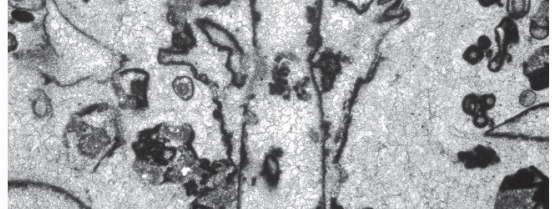
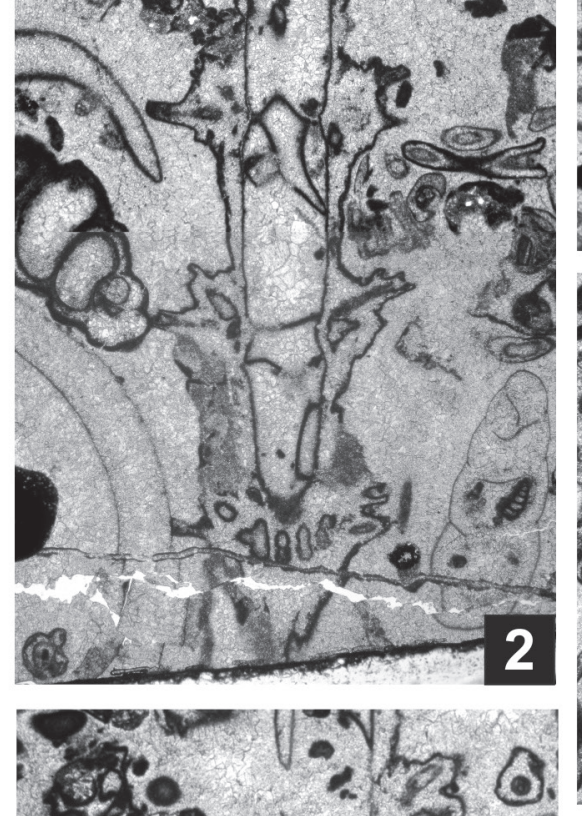
$82^{2}\left(w^{2} \cdot\right)^{2}$ (6)

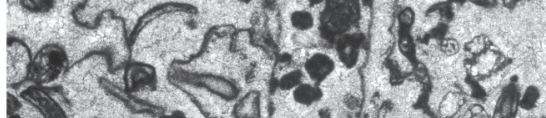

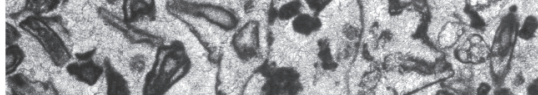

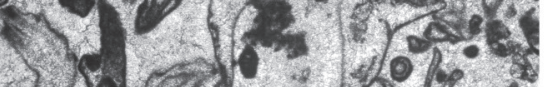

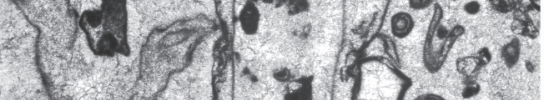
a)

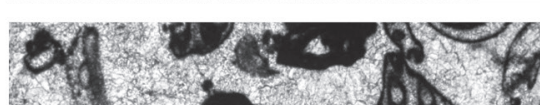

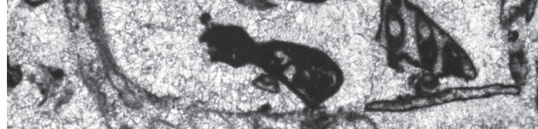
$-1000080 \%$ \% 1.

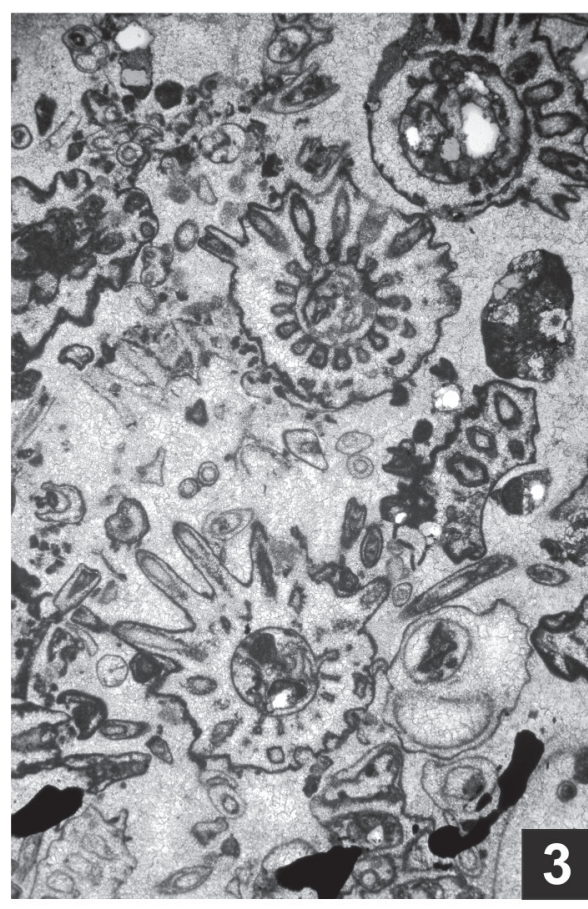

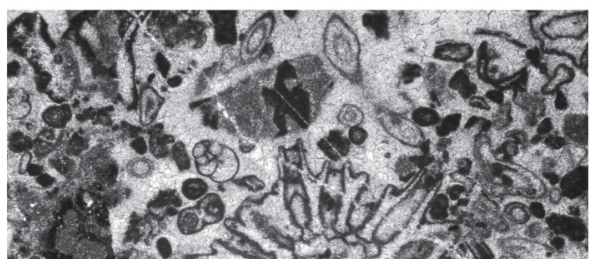

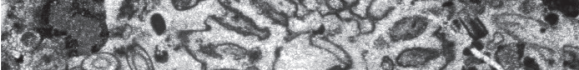

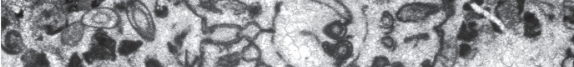

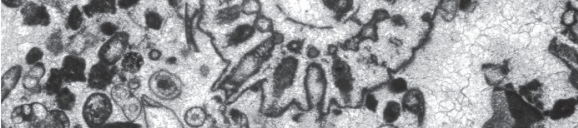

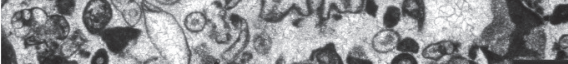

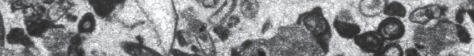

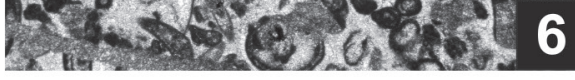

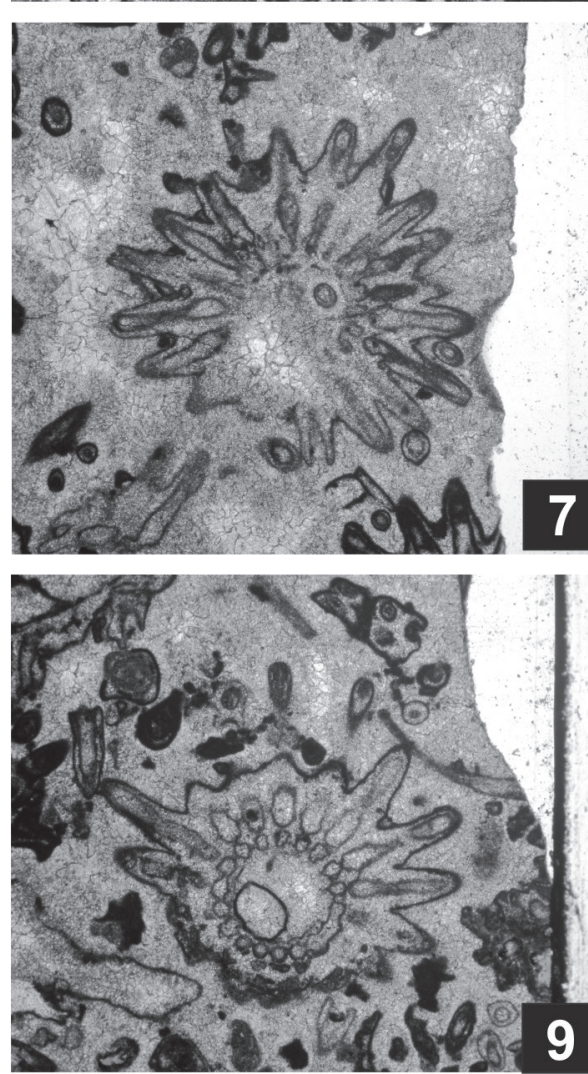




\section{Plate XV}

1-14 Selliporella cornutuformis $\mathrm{n}$. sp.

1-2 Tangential-oblique sections. Fig. 1, arrow - a small output pore of the primary lateral. Slides: fig. 1, PPB-125; fig. 2, KOB-372, x12,5.

3-4,6 Oblique sections. The comparison of these cross sections shows differentiated and differently directed secondary laterals. Figure 6, arrow - mildly inflated primary lateral. Slides: fig. 3, SB-8C/1; fig. 4, SB-8C/2; fig. 6, SB-8C, x12,5.

5,7-8 Longitudinal sections. Figs. 7-8 demonstrate the basal part of the thallus with undivided pirifer laterals. In both instances the spreading and narrowing of the central cavity is present. Slides: fig. 5; KOB-372/31; fig. 7; BV-52/3; fig. 8, PPB-125/4, x12,5.

9-11 Transverse sections. The distal individualization of the secondary laterals in the shape of the spine is clearly visible. Slides: fig. 9, SB-8C/1; fig. 10, PPB-125; fig. 11, PPB-125/3, x12,5.

12 Tangential section of a segment. The section points to, or suggests, a larger number of secondary laterals. Slide: SB-8B/1, x12,5.

13 Transverse, slightly oblique section. Slide: SB-8C/1, x12,5.

14 Cross section of part of the thallus between whorls. Calcareous envelope is perforated by a vertical tubule of unknown origin and function. Slide: SB-8B/5, $\mathrm{x} 12,5$. 

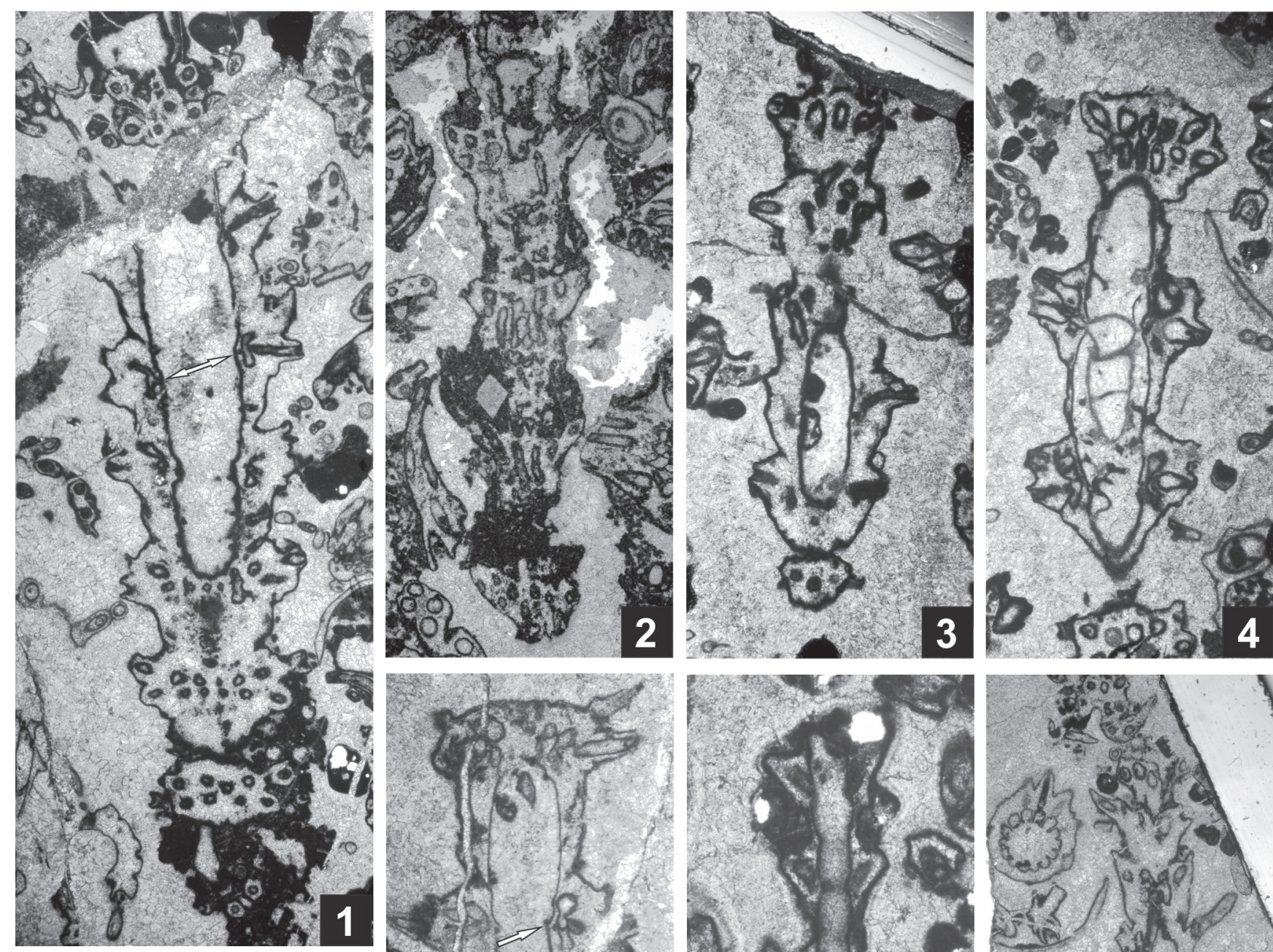

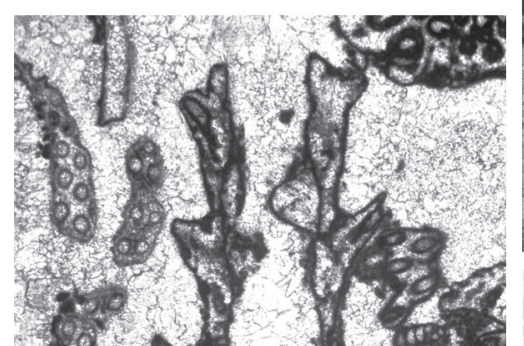
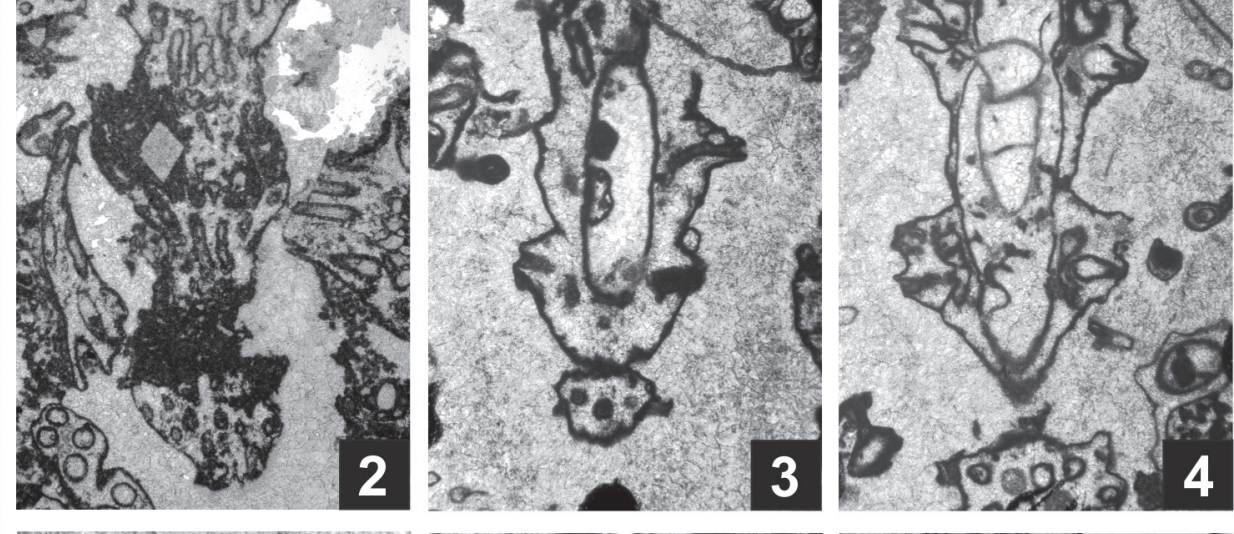

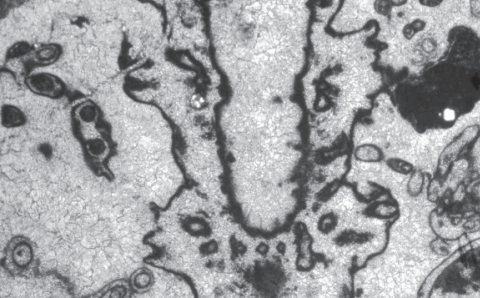
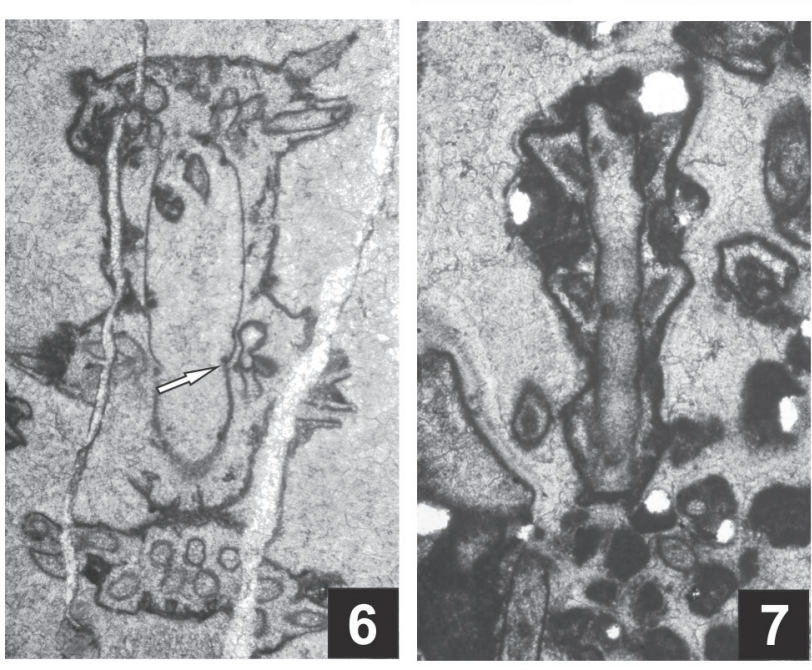

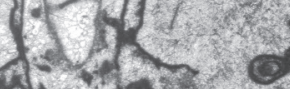
$1+b^{2}-1030$

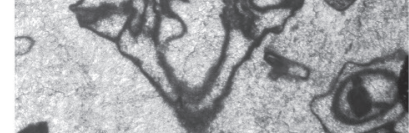

8 s.

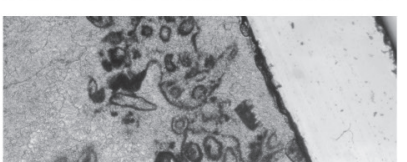

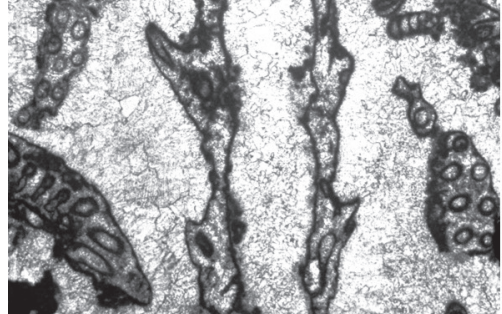
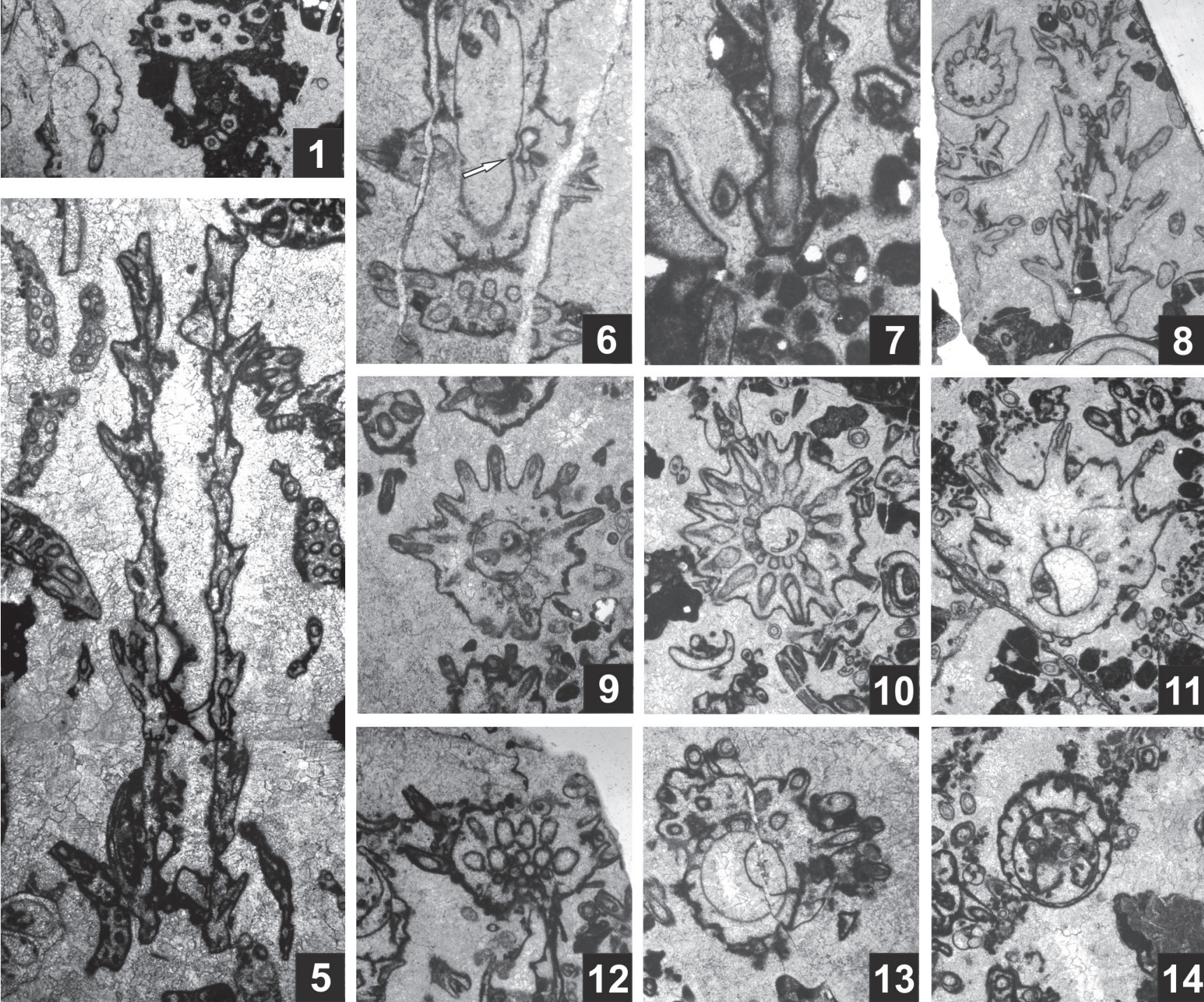

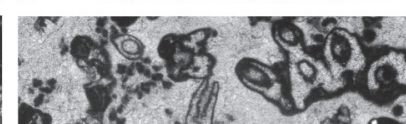

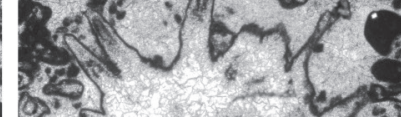

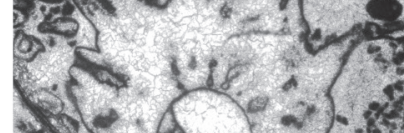

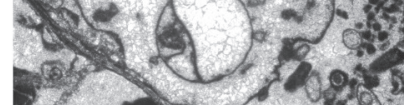

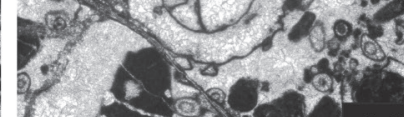

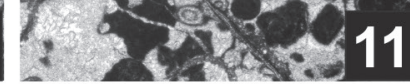
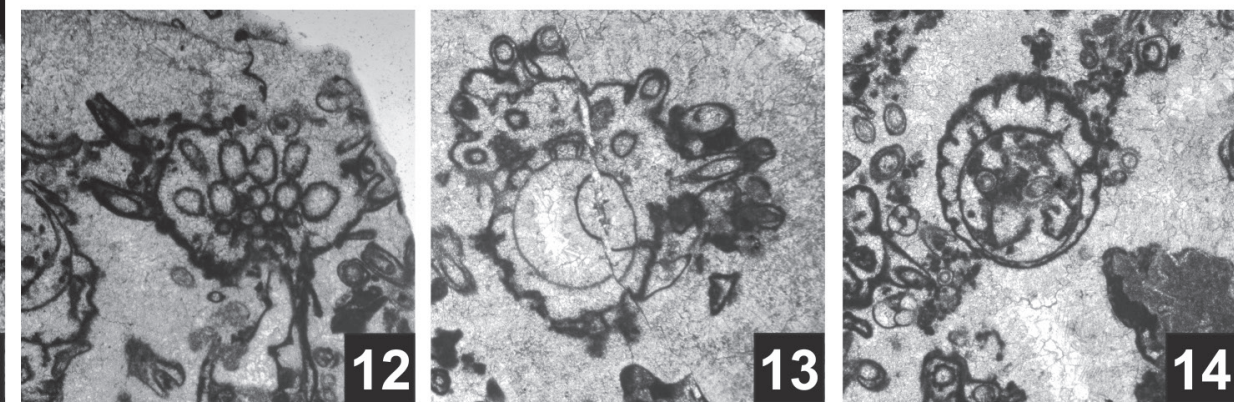

Bis $(25)$

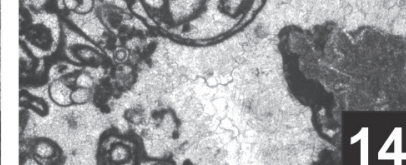




\section{Plate XVI}

1-11 Selliporella cornutuformis $\mathrm{n} . \mathrm{sp}$.

1 Tangential-oblique section. Slide: KOB-372/5, x12,5.

2-4 Longitudinal-tangential section. Slides: fig. 2, KOB-372/4,fig. 3-4, KOB-372/39, x12,5.

5-6 Longitudinal section of two segments. In fig. 5 the differently directed growth of the secondary laterals and tuber-like primary lateral (arrow) is clearly visible. Slides: fig. 5, SB-8C/3; fig. 6, KOB-372/23, x12,5.

7-8 Longitudinal sections demonstrate the sections of the thallus of a different stage of growth. Slides: fig. 7, KOB-372/16; fig. 8, PPB-125/2, x12,5.

9-11 Longitudinal, slightly oblique sections demonstrate different diameters of the secondary laterals. Slides: fig. 9 SB-8B/21; fig. 10, KOB-37/38, fig. 11, SB-8B/18, $\mathrm{x} 12,5$ 

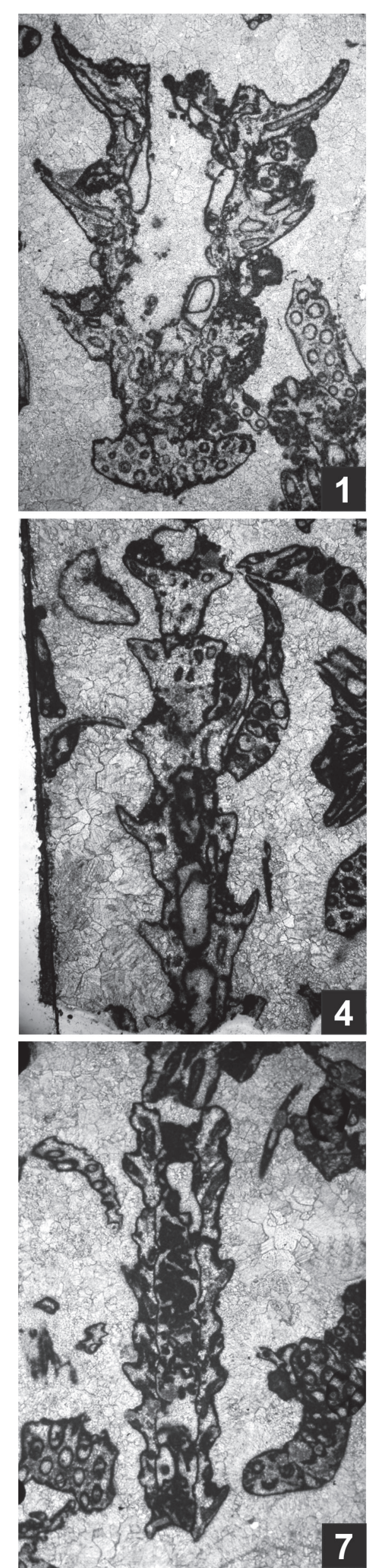
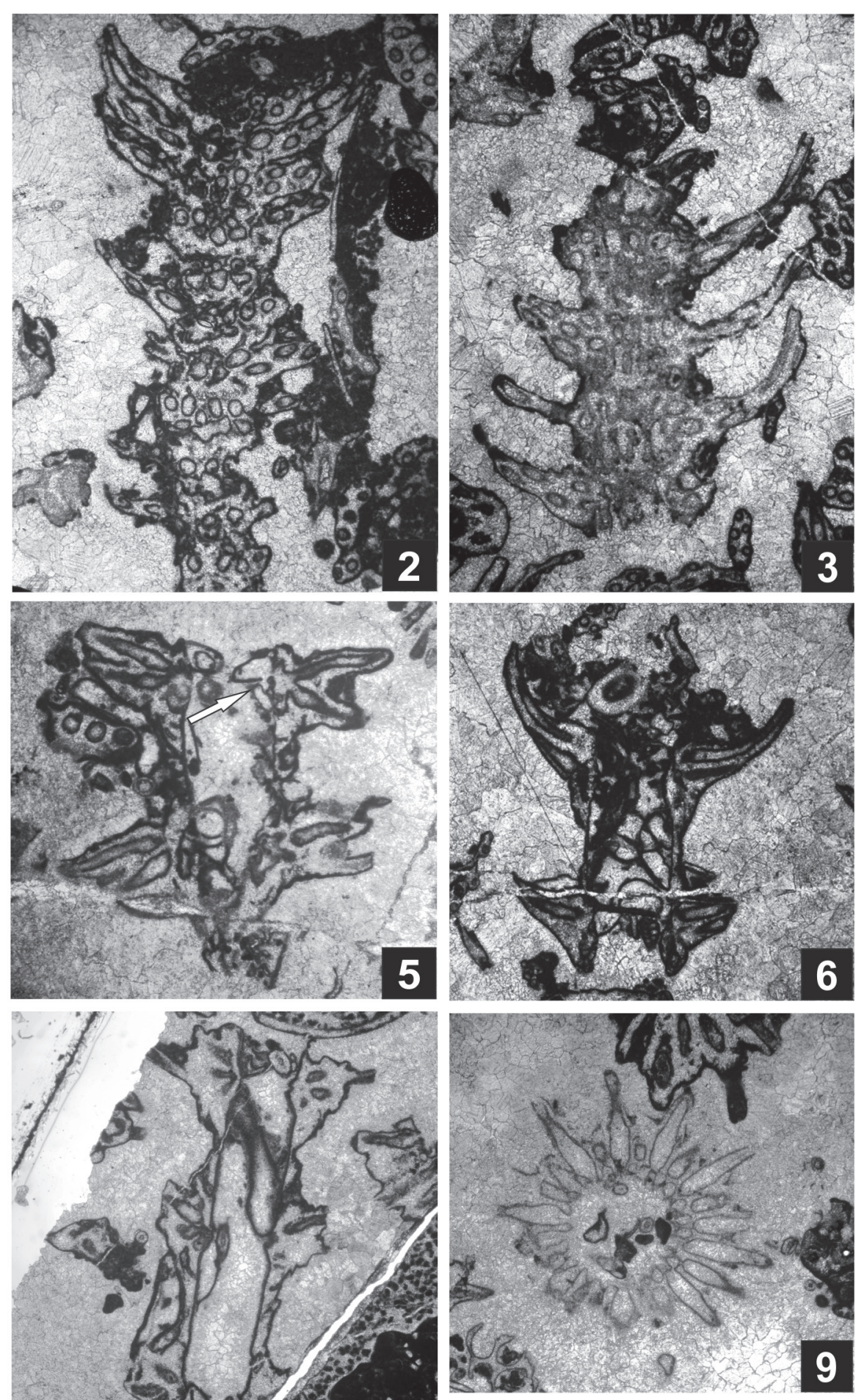

Ga. sel $\left(\frac{2 \pi}{4}\right)$
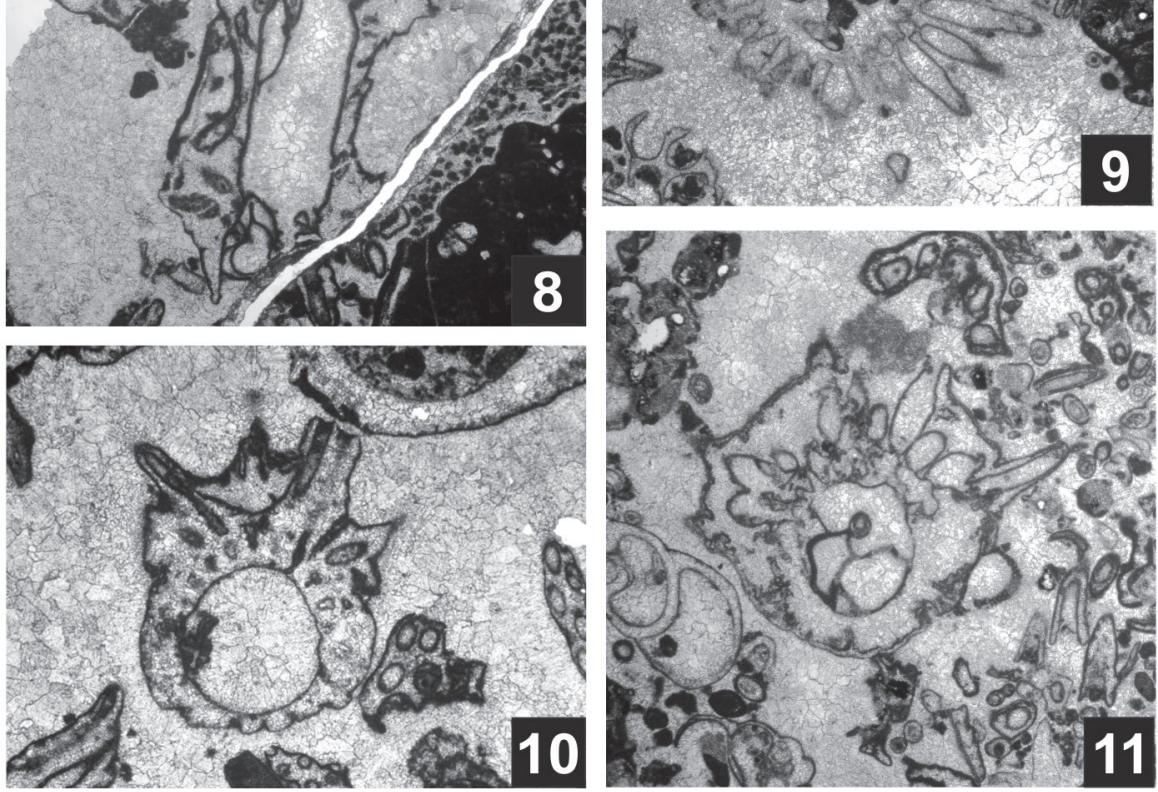


\section{Plate XVII}

1-7 Pseudoclypeinajohnsoni (PRATURLON) n. comb.

1 Longitudinal-oblique, partly tangential section. Slide: Mlj-46, x7,3

2-3 Oblique sections. Slides: fig. 2, Mlj-46/22, fig. 3, Mlj-46/21, x20,4

4 Tangential-oblique section. In the tangential section of the proximal part of the secondary laterals their number is 5-6. Slide: Mlj-46/1, x25.

5 Transverse section. Poorly visible phloiophorous shape and articulation of secondary laterals. Slide: Mlj-46/4, x20,4.

6 Oblique section. Poorly visible phloiophorous shape and articulation of secondary laterals. Slide: Mlj-46/1, x25.

7 A fragment of a transverse section. In the edge section, an enlarged number of small pores is a possible indication of tertiary laterals. Slide: Mlj-46/25, $\times 25$. 

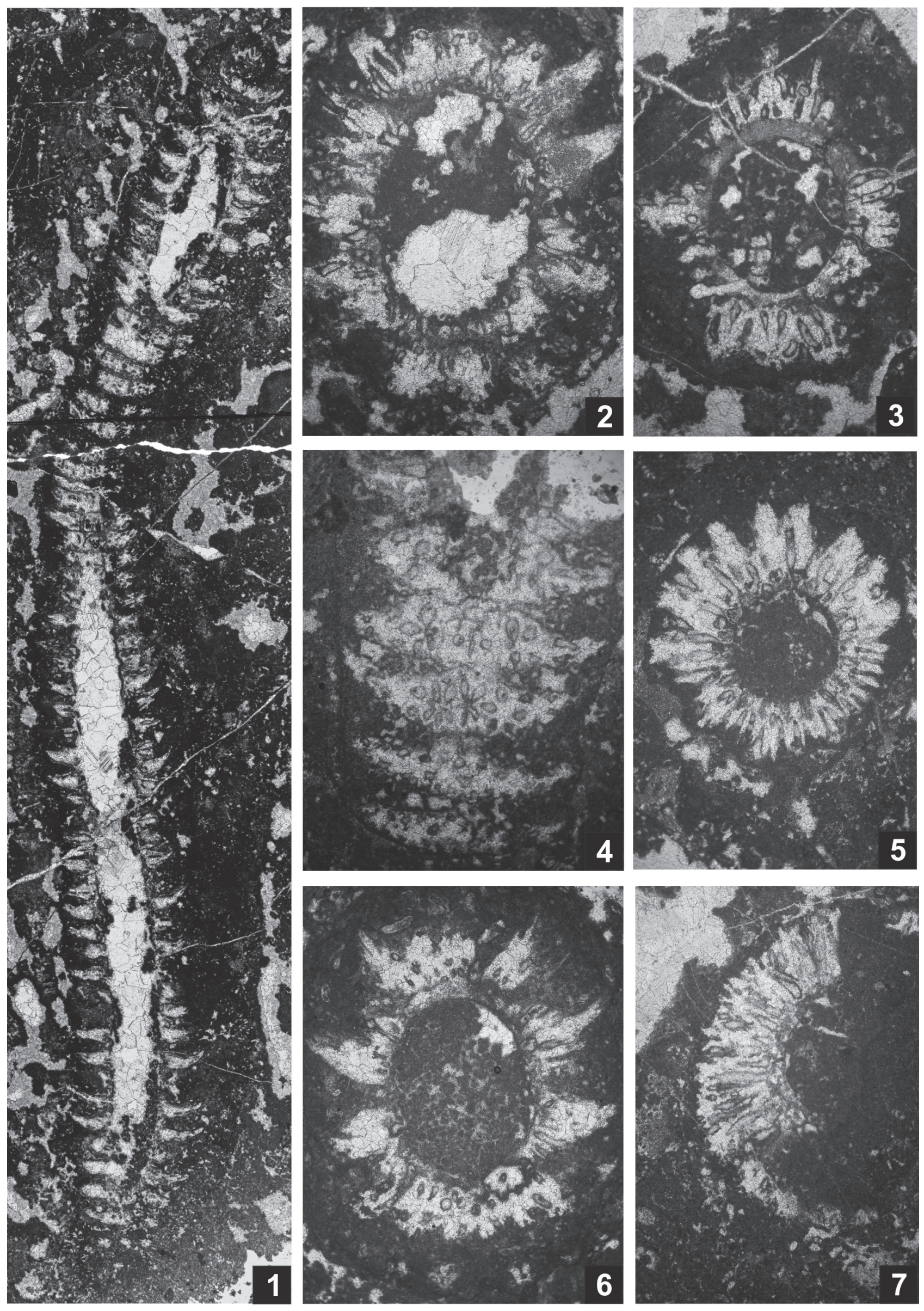


\section{Plate XVIII}

1-8 Pseudoclypeina johnsoni (PRATURLON) n. comb.

1 Oblique-tangential section. Slide: Mlj-46/2, x13

2 Tangential-oblique section. Clearly visible phloiophorous shape of the secondary laterals. Slide: Di-031A/1, x13

3 Oblique section. Slide: Mlj-46/2, x13.

4 Tangential-oblique section. In the tangential section part there are isolated bundles of secondary laterals of adjacent articles. The number of secondary laterals is 6,?7. Slide: Di-031A/4, x25.

5 Longitudinal section. The slight waviness of the central cavity with the incisions at the level of the primary laterals is visible. Slide: Di-031A, $x 25$.

6-7 Fragments of tangential sections of isolated bundles of adjacent articles. The number of pores of secondary lateral branches in the individual bundles is 6.Slides: fig. 6, Di-031A/3; fig. 7, Di-031A/4, x25.

8 Cross section of two adjacent articles. See the articulation of secondary lateral - arrow. Slide: Mlj-46/18, x20,4 

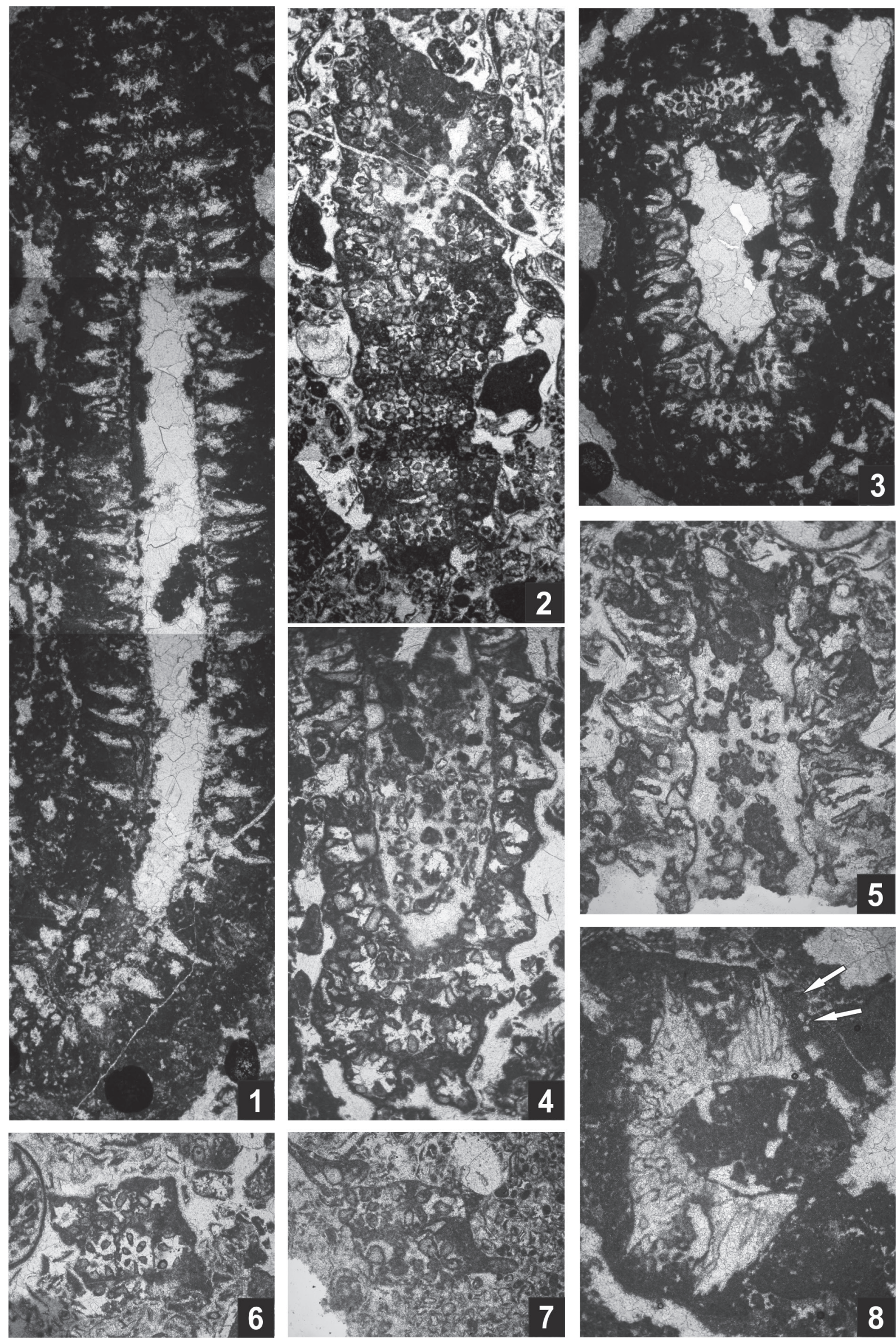
(6) 20,35 ?

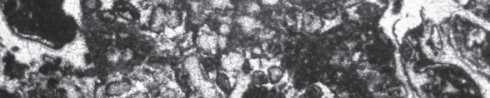
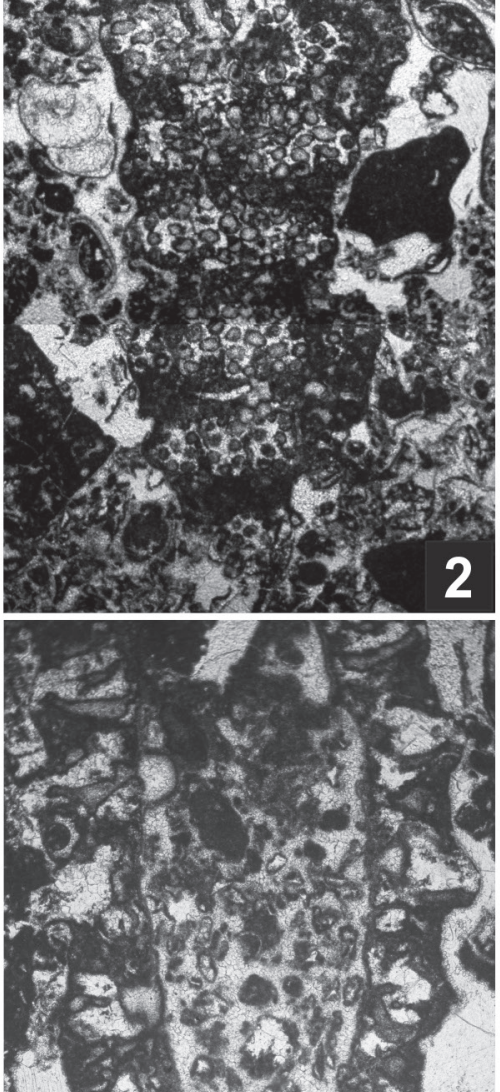

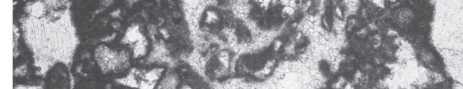
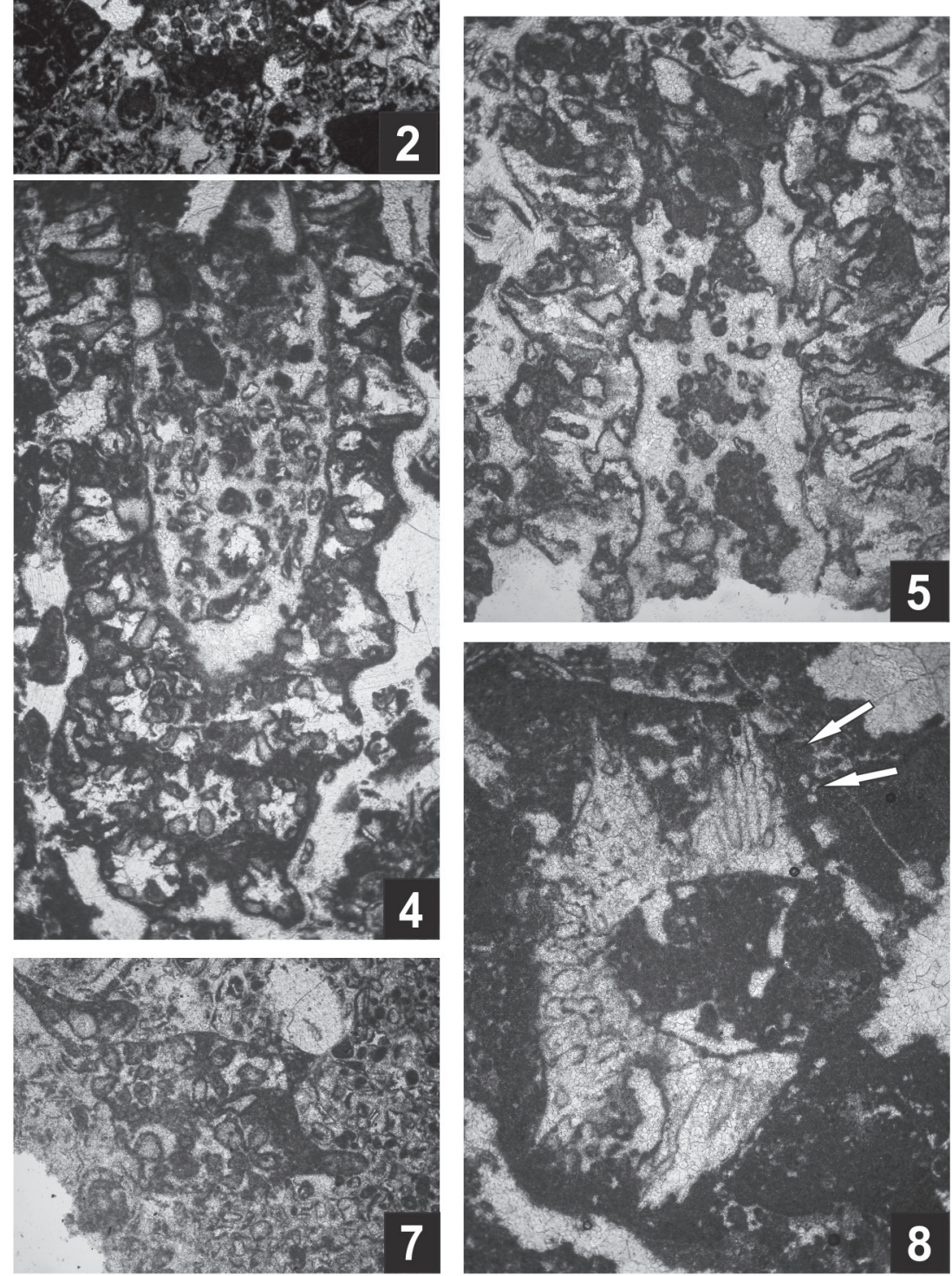


\section{Plate XIX}

1-10 Pseudoclypeina johnsoni (PRATURLON) n. comb.

1 Oblique section. Irregularly inflated primary laterals are visible. Slide: Mlj-46/3, x20,4.

2 Oblique section. Slide: Di-031A/7, x25

3 Tangential section. Slide: Di-2A, x13

4 Oblique section. In the outer edge is the indication of the tertiary lateral - arrow. Slide: Mlj-46/17, x20,4.

5 Oblique section. Irregularly inflated primary laterals are visible. Slide: Mlj-46/5, x20,4.

6 Tangential-oblique section. Slide: Mlj-46, x15

7 Slightly oblique section. Clearly visible phloiophorous shape of the secondary laterals and the indications of the tertiary laterals is expresse - arrow. Slide: Mlj-46/3, ×20,4.

8 Slightly oblique section. See the articulation of secondary lateral - arrow.Slide: Mlj-46/5, x20,4.

9 Oblique section. Slide: Mlj-46/3, x13.

10 Transverse section. Slide: Di-031B/5, x13 

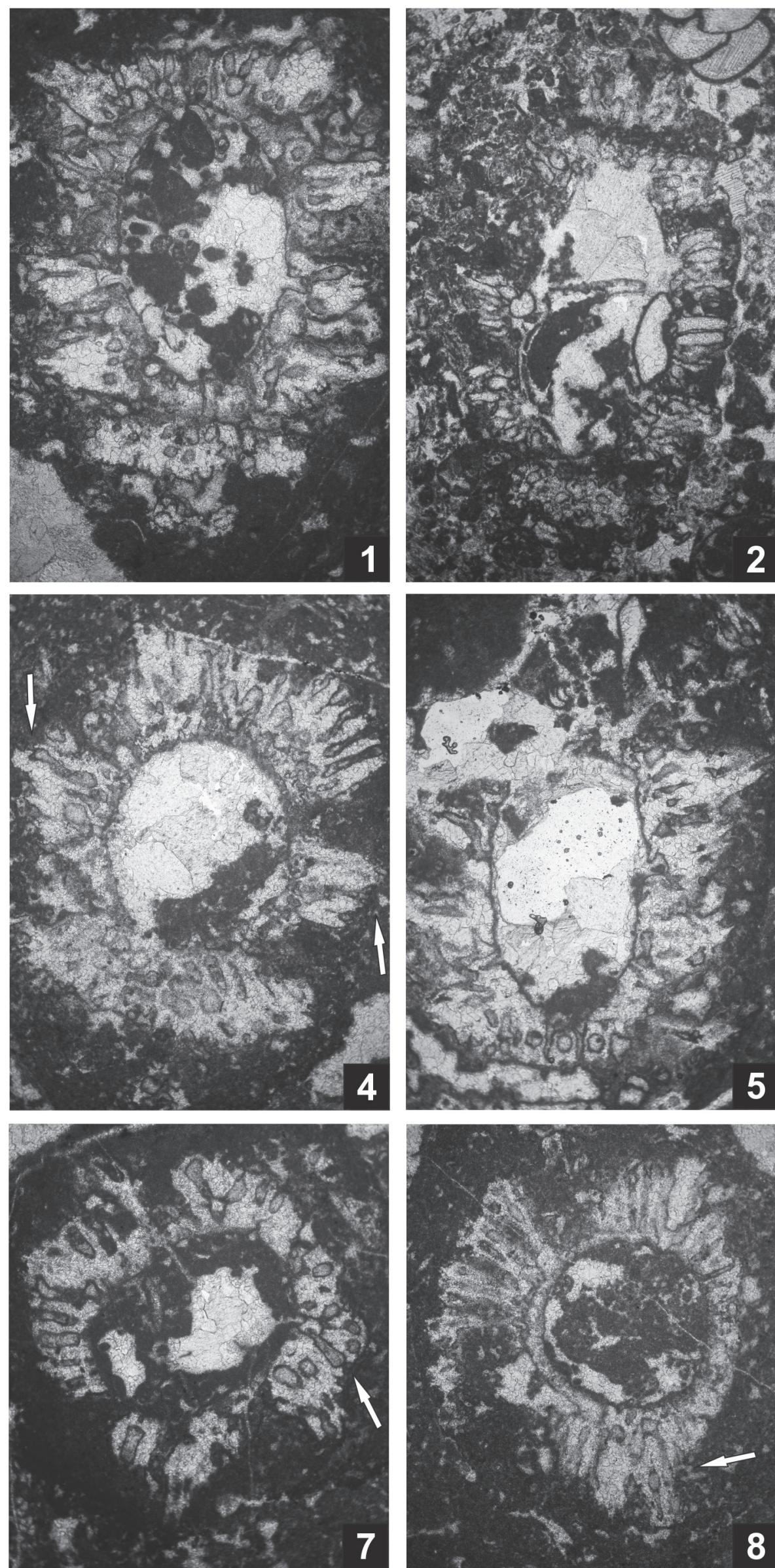
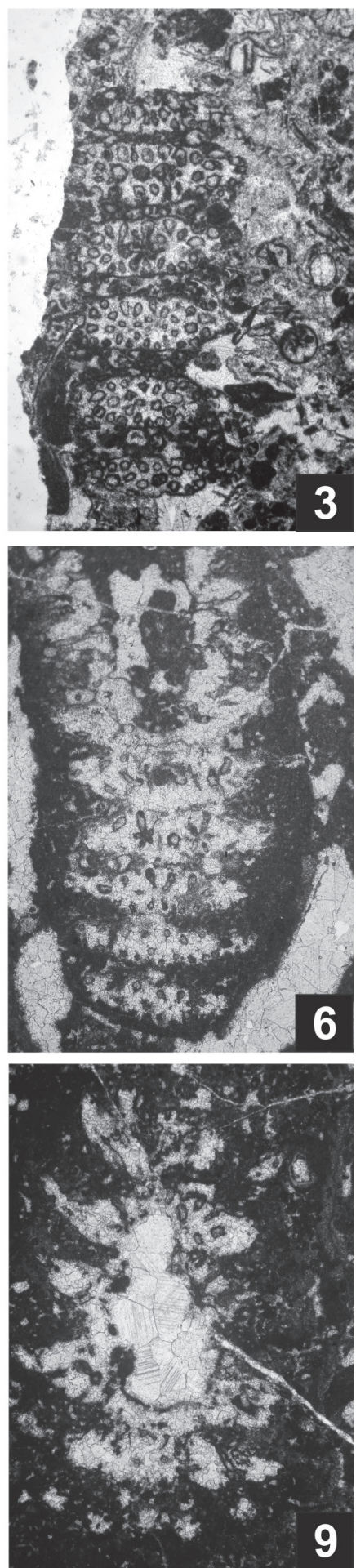

Tro our Not

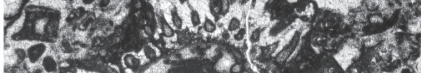

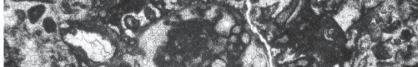

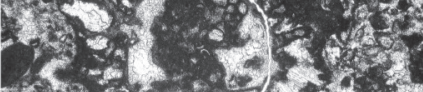
$5-2-2+6$ cent 1 .

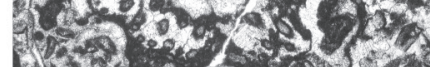
$1672=028$

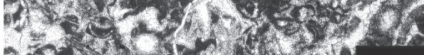
6. 